Florida International University FIU Digital Commons

$3-7-2011$

\title{
Antibacterial Proteins and Peptides in Nurse Shark (Ginglymostoma Cirratum) Peripheral Blood Leukocytes
}

Nichole Hinds Vaughan

Florida International University, nhinds01@fiu.edu

DOI: $10.25148 /$ etd.FI1 1042708

Follow this and additional works at: https://digitalcommons.fiu.edu/etd

\section{Recommended Citation}

Hinds Vaughan, Nichole, "Antibacterial Proteins and Peptides in Nurse Shark (Ginglymostoma Cirratum) Peripheral Blood Leukocytes" (2011). FIU Electronic Theses and Dissertations. 369.

https://digitalcommons.fiu.edu/etd/369 


\section{FLORIDA INTERNATIONAL UNIVERSITY}

Miami, Florida

\section{ANTIBACTERIAL PROTEINS AND PEPTIDES IN NURSE SHARK (GINGLYMOSTOMA CIRRATUM) PERIPHERAL BLOOD LEUKOCYTES}

A dissertation submitted in partial fulfillment of the requirements for the degree of DOCTOR OF PHILOSOPHY

in BIOLOGY

by

Nichole Hinds Vaughan 
To: Dean Kenneth Furton

College of Arts and Sciences

This dissertation, written by Nichole Hinds Vaughan, and entitled Antibacterial Proteins and Peptides in Nurse Shark (Ginglymostoma Cirratum) Peripheral Blood Leukocytes, having been approved in respect to style and intellectual content, is referred to you for judgment.

We have read this dissertation and recommend that it be approved.

$\begin{array}{r}\hline \text { Alejandro Barbieri } \\ \hline \text { John Makemson } \\ \hline \text { Laurie Richardson } \\ \hline \text { Sylvia L. Smith } \\ \hline \text { Charles H. Bigger, Major Professor }\end{array}$

Date of Defense: March 7, 2011

This dissertation of Nichole Hinds Vaughan is approved.

\begin{tabular}{c}
\hline $\begin{array}{c}\text { Dean Kenneth Furton } \\
\text { College of Arts and Sciences }\end{array}$ \\
\hline Interim Dean Kevin O'Shea \\
University Graduate School
\end{tabular}

Florida International University, 2011 
(C) Copyright 2011 by Nichole Hinds Vaughan

All rights reserved. 


\section{DEDICATION}

I dedicate this dissertation to my mom and dad, who taught me that anything was possible if I believed in myself. You are both sorely missed.

To my husband, Robert, and my daughter, Maya, you are my light! 


\section{ACKNOWLEDGMENTS}

There are many people who have contributed in one way or another to the successful completion of this study. While it would be impossible to list everyone individually, I would like to say a big thank you, from the bottom of my heart, to everyone who assisted me along the way. In particular, I wish to thank Dr. Sylvia Smith for her consistent mentorship, keen scientific observations and for her expert advice. I would also like to thank Dr. Charles Bigger and the members of my committee for their patience and dedication to moving me forward through this process.

I would like to thank my dear friend Liza Merly for her sage advice and steadfast support. Thanks as well to Juan Oves for his reliability and assistance in the lab, and to Lorenzo Menzel for his expertise.

.....And last but not least, I would like to thank my sisters, who drive me crazy,

while keeping me perfectly sane. Thanks for the endless babysitting and for your lifelong belief in me. 


\title{
ABSTRACT OF THE DISSERTATION
}

ANTIBACTERIAL PROTEINS AND PEPTIDES IN NURSE SHARK (GINGLYMOSTOMA

\section{CIRRATUM) PERIPHERAL BLOOD LEUKOCYTES}

\author{
by
}

Nichole Hinds Vaughan

Florida International University, 2011

Miami, Florida

Professor Charles H. Bigger, Major Professor

In many vertebrate and invertebrate species mediators of innate immunity include antimicrobial peptides (AMPs) such as peptide fragments of histones and other proteins with previously ascribed different functions. Shark AMPs have not been described and this research examines the antibacterial activity of nurse shark (Ginglymostoma cirratum) peripheral blood leukocyte lysates. Screening of lysates prepared by homogenizing unstimulated peripheral blood leukocytes identified muramidase (lysozyme-like) and non-muramidase antibacterial activity. Lysates were tested for lysozyme using the lysoplate assays, and antibacterial (AB) activity was assayed for by a microdilution growth assay that was developed using Planococcus citreus as the target bacterium. Fractionation of crude lysates by ion exchange and affinity chromatography was followed by a combination of SDS-PAGE with LC/MS-MS and/or N-terminal sequence analysis of low molecular weight protein bands (<20 kDa). This yielded several peptides with amino acid sequence similarity to lysozyme, ubiquitin, hemoglobin, human histones $\mathrm{H} 2 \mathrm{~A}, \mathrm{H} 2 \mathrm{~B}$ and $\mathrm{H} 4$ and to antibacterial histone fragments of 
the catfish and the Asian toad. Not all peptide sequences corresponded to peptides potentially antibacterial. The correlation of a specific protein band in active lysate fractions was accomplished by employing the acid-urea gel overlay assays in which $A B$ activity was seen as zones of growth inhibition on a lawn of $P$. citreus at a position corresponding to that of the putative $A B$ protein band. This study is the first to describe putative AMPs in the shark and their potential role in innate immunity. 
$\begin{array}{ll}\text { I. INTRODUCTION } & 1\end{array}$

II. BACKGROUND 6

Intracellular Immune Factors $\quad 6$

Antimicrobial Proteins $\quad 8$

$\begin{array}{ll}\text { Antimicrobial Peptides } & 11\end{array}$

$\begin{array}{ll}\text { Characterization of Antimicrobial Peptides } & 14\end{array}$

$\begin{array}{ll}\text { Mechanism of Action of Antimicrobial Peptides } & 17\end{array}$

Histones as Novel Antimicrobial Peptides $\quad 21$

Immunomodulatory Effects of Antimicrobial Peptides 25

Significance of Antimicrobial Peptides $\quad 26$

Significance of Elasmobranchi as a Model System 29

Goals and Hypothesis $\quad 30$

III. MATERIAL S AND METHODS 32

Blood Collection $\quad 32$

Preparation of Cytospins $\quad 33$

Isolation of Peripheral Blood Leukocytes 33

Trypan Blue Exclusion Test $\quad 35$

Preparation of Leukocyte Lysates $\quad 35$

Concentration and Dialysis of Lysates $\quad 36$

Detection and Quantitation of Antibacterial Activity 37

$\begin{array}{ll}\text {--Screening methods } & 37\end{array}$

--Microdilution growth assay $\quad 40$

Fractionation of Cell Lysates $\quad 43$

--Anion exchange chromatography using DE 52 Cellulose 44

--Anion exchange chromatography using Q Sepharose and DE
Sepharose

--Heparin-sepharose affinity chromatography $\quad 45$

SDS-PAGE Analysis of Chromatography Fractions 46

$\begin{array}{ll}\text { Western Blot } & 47\end{array}$

Correlation of Antibacterial Activity with Specific Protein Bands 49

Amino Acid Sequence Analysis of Lysate Proteins/Peptides 50

--Protein search algorithm $\quad 52$ 
IV. RESULTS 53

Composition of Leukocyte Fraction of Shark Peripheral Blood 53

--Structural morphology of cell types 53

--Differential count of cell types $\quad 55$

Detection and Quantitation of Antibacterial Activity of Leukocyte Lysate $\quad 55$

--Development of a microdilution growth assay 58

--Application of standard assay to titrate antibacterial activity in lysates $\quad 64$

Fractionation of Cell Lysates and Protein Analysis of Active Fractions 65 --Protocol I:DE Cellulose-Heparin $\quad 65$

--Protocol IIA:DE Sepharose-glass homogenized lysate 68

Fractionation of Cell Lysates and Correlation of Antibacterial Activity

$\begin{array}{ll}\text { with Specific Protein Bands } & 72\end{array}$

--Protocol IIB:DE Sepharose-sonicate lysate I $\quad 72$

--Protocol IIC-1:DE Sepharose-sonicate lysate II 75

--Protocol IIC-2:DE Sepharose-sonicate lysate III 79

Western Blot Analysis $\quad 82$

$\begin{array}{llr}\text { V. DISCUSSION } & 84\end{array}$

$\begin{array}{ll}\text { BIBLIOGRAPHY } & 94\end{array}$

$\begin{array}{ll}\text { APPENDIX } & 118\end{array}$

$\begin{array}{ll}\text { VITA } & 133\end{array}$ 


\section{LIST OF TABLES}

TABLE

PAGE

1. Relative Numbers of Different Leukocytes In Nurse Shark (present study) and Human Peripheral Blood

2. Quantitation of Antibacterial Activity of Different Preparations of Leukocyte Lysates

3. Effect of pH and Salinity on Growth of Planococcus citreus

4. Effect of Temperature on P. citreus Growth and Antibacterial Activity of Leukocyte Lysate

5. N-Terminal Amino Acid Sequence of Proteins Isolated from Shark Leukocyte Lysate Analyzed by Edman Degradation

6. Internal Amino Acid Sequence Analysis of Proteins Isolated from Shark Leukocyte Lysate Analyzed by LC/MS-MS

7. Alignment of Amino Acid Sequence of Shark Histone Fragments 


\section{LIST OF FIGURES}

FIGURE

PAGE

1. Cytospins of nurse shark peripheral blood cells 54

2. Representative radial diffusion assay plates 57

3. Growth of Planococcus citreus in Sea water Complete Medium 59

4. Antibacterial effect of leukocyte lysates on growth of Planococcus citreus at different target cell densities

5. Antibacterial activity of diluted and concentrated samples of crude leukocyte lysate

6. Variation in the antibacterial activity of different lysate preparations from different bleeds

7. Protocol I: Fractionation of leukocyte lysate on DE Cellulose

8. Protocol I: Fractionation of Pool I from the first DE Cellulose column

9. Protocol I: Fractionation of the combined pools from two DE Cellulose columns (see text) on Heparin Affinity column and SDS-PAGE analysis

10. Protocol IIA: Fractionation of leukocyte lysate on DE Sepharose and SDS-PAGE analysis

11. Protocol IIB: Fractionation of lysate on DE Sepharose column

12. Acid-Urea PAGE analysis of concentrated Pool I (Protocol IIB)

13. SDS-PAGE Analysis of Pool I from DE Sepharose column (Protocol IIB)

15. SDS-PAGE analysis of fractions from DE Sepharose column 
16. Acid-Urea PAGE analysis of concentrated pools of DE Sepharose (Protocol IIC-1)

17. Protocol IIC-1: Fractionation of Pool IV from first DE Sepharose column

18. Protocol IIC-2: Fractionation of lysate on DE Sepharose column

79

19. SDS-PAGE analysis of fractions from DE Sepharose column (Protocol IIC-2)

80

20. Acid-Urea Gel analysis of fractions from DE Sepharose (Protocol IIC-2)

81

21. Acid-Urea Gel analysis of Pool I (Protocol IIC-2)

81

22. Western blot analysis

83 


\section{INTRODUCTION}

The mammalian immune system is a complex network of cells, organs, tissue, and soluble protein substances that interact to protect the body from foreign materials, recognized as non-self. This protection can take the form of an adaptive, targeted response or an innate and immediate response. Immune cells will surveil, and detect, non-native molecules and either mount an attack or call in reinforcements, or both (Klein 1997).

The innate immune system is comprised of several components: (1) physical and chemical barriers such as the skin, the low $\mathrm{pH}$ of the stomach, and the sweeping motion of the cilia in the airway; (2) cellular and (3) humoral factors. The cellular components consist of a variety of different cell types that include macrophage/monocytes, granulocytes such as neutrophils, basophils and eosinophils, mast cells, dendritic cells and natural killer cells and can function by direct intervention through either engulfment of the foreign particle or by indirect interaction when stimulated through subsequent secretion of soluble proteins (Kindt et al. 2007). Humoral factors include soluble proteins such as complement proteins, hydrolyzing enzymes, cytokines and the ubiquitous antimicrobial peptides (Kindt et al. 2007). Antimicrobial peptides, key mediators of innate immune function, have emerged as effective defense molecules, patrolling host borders, fighting off and killing invading pathogens, and acting as the first line of defense. 
Antimicrobial peptides, which have recently been renamed as host defense peptides (Steinstraesser et al. 2009), play a significant role in angiogenesis (Huang et al. 1997; Li et al. 2000), chemotaxis (Fleischmann et al. 1985; Ichinose et al. 1996), cytokine production (Chaly et al. 2000), histamine release (Befus et al. 1999; Niyonsaba et al. 2001), lipopolysaccharide (LPS)-binding (Nagaoka et al. 2001; Nagaoka et al. 2002) and other immunomodulatory activities (Yang et al. 2002; Bals et al. 2003; Bowdish et al. 2005). However, the main function of antimicrobial peptides is to kill microbes. Collectively, these peptides exhibit a broad spectrum of activity against microbes, including gram positive and gram negative bacteria, fungi, mycoplasma, and viruses (reviewed in Boman, 1998).

Antimicrobial peptides have been isolated from a wide variety of animals. They are present in several vertebrates including mammals (Selsted et al. 1985; Zanetti et al. 1995), birds (Harwig et al. 1994; Sugiarto et al. 2004), amphibians (Zasloff 1987) and teleost fish, (Cole et al. 1997; Noga et al. 2003) and in invertebrates, such as insects (Boman et al. 1985; Casteels et al. 1989; Moore et al. 1996), horse-shoe crabs (Schnapp et al. 1996; Relf et al. 1999), tunicates (Lee et al. 1997) and shrimp (Destoumieux et al. 1997). They have also been documented in plants (Rinehart et al. 1990; Harrison et al. 1999; Stephens et al. 2005) and bacteria (Boman 1998, 2003; Sang et al. 2008).

To date, little is known of antimicrobial peptides in elasmobranchs, including sharks, although antimicrobial proteins such as transferrin (Davies et al. 1987) and squalamine, an aminosterol (Moore et al. 1993), have been identified in the dogfish shark. A cationic antimicrobial peptide has been described for the fermented skate, Raja kenojei, from 
skin extracts (Cho et al. 2005). There have also been some functional studies conducted on lysozyme-like activity using nurse shark serum (Hedayati 1992). There are many generalities shared by this class of vertebrates. Each species, however, must be examined on its own merit. Rays, sharks and other elasmobranchs display many differences in habitat, behavior and physiology. Even sharks within the same subdivision differ in some features as fundamental as the function of hematopoietic organs (Fange 1977), therefore It is unwise to use one species of sharks to wholly represent other species.

Most investigators studying the immune system of the shark focus on adaptive immune mechanisms (Greenberg et al. 1995; Ohta et al. 2002; Rumfelt et al. 2002; Dooley et al. 2005; Haines et al. 2005; Zhang et al. 2006; Flajnik et al. 2009). Research is also being conducted on innate immune mechanisms of the shark, particularly the complement system and the role and function of circulating leukocytes (Smith et al. 1989; Dodds et al. 1998; Merly et al. 2007; Shin et al. 2007; Aybar et al. 2009; Graham et al. 2009; Shin et al. 2009). The composition of shark peripheral blood differs from humans in several ways (Hyder et al. 1983). Firstly, shark serum contains relatively high concentrations of salt $(0.25 \mathrm{M})$ and urea $(0.35 \mathrm{M})$ and its complement proteins have certain unique features. In addition, the bulk protein in serum is not albumin, as is seen in most mammals, but rather immunoglobulin (natural antibody) which can amount to as much as $40 \%$ of total serum protein. Secondly, the cellular components of shark blood also show differences. Curiously, there has not been a published histological study using light microscopy, of nurse shark (the shark used in this study) peripheral 
blood leukocytes. However, some general cellular characteristics prevail. Unlike the non-nucleated discoidal human erythrocytes, shark mature erythrocytes are nucleated ellipsoidal structures. Shark granulocytic leukocytes morphologically resemble mammalian neutrophils and eosinophils, and the mononuclear cells are similar to lymphocytes and monocyte/macrophages. The shark granulocytes and monocyte/macrophages have been shown to be phagocytic and chemotactic cells (Hyder et al. 1983; Obenauf et al. 1985). In addition, shark blood contains the thrombocyte, a cell absent from mammalian peripheral blood. Thrombocytes are believed to play a role in coagulation, similar to that of human platelets which the shark lacks. The shark lacks bone marrow (its skeleton is composed of cartilage) and it is not unusual to find immature undifferentiated cells circulating in peripheral blood (Hyder et al. 1983).

Antimicrobial peptides can be produced by a variety of cell types such as: hemocytes of the crab (Schnapp et al. 1996), cecropia moth (Steiner et al. 1981) and pacific shrimp (Patat et al. 2004), mammalian paneth cells (Mallow et al. 1996), epithelial cells (Diamond et al. 1991), and neutrophils (Befus et al. 1999); and skin mucosa of fish (Cho et al. 2002) and frogs (Zasloff 1987). To date, no investigation has been undertaken to investigate the antimicrobial proteins and/or peptides associated with circulating leukocytes in the nurse shark.

The major objective of this research is the identification and characterization of antibacterial activity of nurse shark, Ginglymostoma cirratum, peripheral blood leukocytes. Peripheral blood leukocytes were chosen as the cell population to study 
since circulating leukocytes in other vertebrate species play an important role in the initial line of defense and are known to secrete a variety of antimicrobial peptides (Spitznagel 1984, 1990). Earlier studies showed two distinctly different types of antimicrobial activity associated with shark peripheral leukocytes: a lysozyme-like activity and a non-lysozyme-like antibacterial activity (Hinds et al. 2001). 


\section{BACKGROUND}

In plants and animals, gene-encoded antimicrobial peptides are rapidly expressed and delivered directly to sites of microbial infiltration (Boman 1998, 2003). This rapid response, though non-specific, differs from the clonally based adaptive immune response (Burnet 1957), which is an acquired response to stimuli.

\section{Intracellular Immune Factors}

When combating an infection, the mammalian innate immune system is called upon to mount an immediate response to invading pathogenic microbes. With generation times of 20-30 min (Boman 1995), this response, once thought to be 'non-specific', can immediately mobilize phagocytic and cytotoxic cells like macrophages, neutrophils, Tcells and Natural killer (NK) cells to release signaling molecules such as interleukins (IL-1, IL-2) and tumor necrosis factor-alpha (TNF- $\alpha$ ) (Klein 1997) and other effector molecules such as lectins (Feizi 2000), NK-lysin (Andersson et al. 1995) or nitric oxide (Fang 1997). The quick response differs from the acquired immune response, which because of its incredible specificity, may take days and even weeks for the clonal expansion of $\mathrm{T}$ and $\mathrm{B}$ lymphocytes to target specific antigens (Klein 1997).

The innate immune defense must selectively destroy or inactivate the invading pathogen, while protecting the structural integrity of the host. In order to do this, receptor mediated recognition of common molecular features differentiating host cells from foreign cells, is necessary. These pathogen-associated molecular patterns (PAMPs) can take the form, for example, of surface associated glycans, formylated 
peptides, lipopolysaccharide, CpG DNA and coat proteins of viruses (Brown 2001;

Girardin et al. 2002). The pattern recognition results in the delivery of effector molecules to the site of infection, such as complement activation on the microbial surface, or antigen/pathogen ingestion followed by the release of reactive oxygen products and granule contents into phagocytic vacuoles (Ganz et al. 1997). These defense mechanisms can inhibit the entry of the microbe, disruption of crucial microbial structures, sequestration of essential nutrients for microbial survival, interference with microbial metabolism, or inhibition of microbial multiplication. These mechanisms utilize inorganic compounds such as hydrogen peroxide, hydrochloric acid, hypochlorous acid, or organic compounds such as chloramines, fatty acids, peptides and proteins (Ganz et al. 1997). The molecules that perform these defense functions (some of which are discussed below) are varied in their physicochemical characteristics, their mechanism of action and their location.

It is evident that the intracellular components are exceedingly potent and are crucial to host defense. The phagocytic cells, neutrophils, monocytes and macrophages play a significant role in immune function, monitoring the body for any invading agent. Once stimulated, these phagocytes possess an impressive arsenal that includes production of bactericidal-reactive oxygen compounds, release of the contents of cytoplasmic granules into the phagosome or the exterior, secretion of cytokine and other regulatory intermediates (thereby attracting other cells to the site of infection), crossing the blood vessel endothelia, with active movement through 
tissue towards source of infection, and production of bactericidal nitric oxide and its derivatives (Klein 1997).

\section{Antimicrobial Proteins}

There are several proteins that are associated with the non-oxidative response in mammalian phagocytic cells that are antimicrobial in nature, one of which is cathepsin $\mathrm{G}$, a serine protease that is found in the azurophilic granules of neutrophils, and some monocytes (Odeberg et al. 1975; Senior et al. 1982; Spitznagel 1990; Kudo et al. 2009). Cathepsin $\mathrm{G}$ is a $26 \mathrm{kDa}$ neutral enzyme that is released by activated neutrophils in humans, and plays an important role in inflammation through the hydrolysis of many different proteins, including extracellular matrix and some chemo-attractants such as TNF- $\alpha$ and IL-8 (Wiedow et al. 2005).

Phospholipase A2 selectively hydrolyzes phospholipids in bacterial membranes, and is a member of a large family of 'secretory' phospholipases that are produced by vertebrates and invertebrates (Dennis 1997). The family of phospholipase A2 shares several highly conserved features, including size (14-16 kDa), high disulfide bond

content, a $\mathrm{Ca}^{2+}$-binding loop, and closely similar catalytic machinery and secondary and tertiary structure (Dennis 1997; Ganz et al. 1997). Bactericidal/permeability-increasing protein, BPI, is a highly cationic protein known for its potent and selective cytotoxic activity toward gram-negative bacteria and its high affinity for LPS (Elsbach et al. 1993).

Transferrins are non-heme, globular, iron-binding glycoproteins, found in the serum of most vertebrates; they are also present in avian egg white and in mammalian 
milk (Putnam 1975; Ingram 1980). Human transferrin has an approximate molecular weight of 80-90 kDa and displays bacteriostatic activity when not fully saturated with iron. Its role when confronting a bacterial infection consists of chelating any free available iron present, making it unavailable to the invading organism (Weinberg 1974; Ingram 1980). Lactoferrin, a member of the transferrin family, is a high affinity ironchelator in milk, and also displays bacteriostatic properties (Bullen et al. 1979; Ellison et al. 1991; Bellamy et al. 1993). Lactoferrin has been found to contain an antimicrobial sequence near its $\mathrm{N}$-terminus which appears to function by a mechanism distinct from iron chelation (Tomita et al 1994). Antimicrobial peptides representing this bactericidal domain of lactoferrin were isolated following pepsin cleavage of human lactoferrin and bovine lactoferrin. The resultant antimicrobial peptide was termed lactoferricin, and has been shown to have potent broad spectrum, lethal antimicrobial properties, causing a rapid loss of colony-forming capability (Tomita et al. 1994). The antimicrobial activity of lactoferrin is often linked with lysozyme (Ellison et al. 1991). In humans both these enzymes are found in polymorphonuclear leukocytes (PMN), i.e., neutrophils, and are also present in high concentration in human mucosal secretions (Masson et al. 1966; Bullen et al. 1979; Ellison et al. 1991).

Lysozyme is a basic, cationic protein, and of particular interest because its main biological function is protection of the host against bacterial infections (Imoto 1972). It induces bacterial cell lysis by hydrolyzing the $\beta-1-4$ linked glycosidic bonds of the peptidoglycan cell wall (Imoto 1972), and is produced mainly by monocytes and 
granulocytic blood cells in mammals (Jolles et al. 1966; Pruzanski et al. 1969). There are two main types of lysozyme that have been described from birds (Jolles et al. 1984) and have been termed c-type (e.g., hen egg white lysozyme) and g-type (e.g., goose egg white lysozyme). These two main types of lysozyme differ slightly in their amino acid sequence and molecular weight. The G-Type lysozyme has low cysteine and tryptophan content and has a higher molecular weight of $21 \mathrm{kDa}$ than the c-type lysozyme (14 kDa) (Jolles et al. 1984). Other lysozymes have been discovered, and they differ in primary structure, physicochemical and immunological criteria (Jolles 1969; Jolles et al. 1984; Jolles 1996). These other types of lysozyme have been found in bacteria, bacteriophages, plants, the invertebrate sea star, Asterias rubens, and some teleosts (Tsugita et al. 1968; Jolles et al. 1975; Fange 1976). There has been lysozyme-like activity detected in an elasmobranch, using nurse shark serum, however, this activity was not studied in detail (Hedayati 1992). Lysozymes differ in amino acid sequence, molecular weight and enzymatic properties. However, amino acid sequence homology remains in the specificity of the active site responsible for the hydrolysis of the $\beta-1-4$ linkage between $\mathrm{N}$-acetylmuramic acid and $\mathrm{N}$-acetylglucosamine (Jolles et al. 1975).

Lysozyme has also been shown to inhibit chemotaxis of activated leukocytes (Ogundele 1998). Another anti-inflammatory function includes the inhibition of mitogen-induced lymphoblastogenesis (Gordon et al. 1979; Ogundele 1998). Lysozyme has been found to have an indirect effect on the complement system by inhibiting the PMN response towards complement-derived chemotaxins such as 
anaphylatoxins C5a, C3a and C4a (Ogundele 1998). It has been reported to inhibit the classical pathway of serum complement activity in a reaction that is dose-dependent (Ogundele 1998). Its presence as an anti-inflammatory secretory component serves to protect the tissues against secondary damage during acute overwhelming infections (Ogundele 1998). In such situations excessive inflammatory reactions of the complement system would be undesirable and potentially damaging to host cells. Another role suggested for lysozyme is the immune surveillance of membranes and the possibility that it may mediate the antitumor functions of macrophages (Osserman et al. 1973; Osserman 1976).

\section{Antimicrobial Peptides}

There are several classifications for antimicrobials on the basis of their physicochemical characteristics (reviewed in Boman 1995, 2003). Those over 10 kDa are generally classified as antibacterial/antimicrobial proteins while those that are smaller are called peptides. Cathelicidins are members of a large family of peptides, all of whom share a conserved N-terminal precursor structure, cathelin, and highly heterogenous C-terminal peptides. This family includes human LL37, Bac5 and Bac7, porcine cathelicidins, and protegrins (Zanetti et al. 1995; Bucki et al. 2010). Some cathelicidins undergo extracellular proteolytic cleavage that frees the active C-terminal peptide from the precursor, while other members of the family appear active in their original non-cleaved form (Zanetti et al. 1995). Found in most mammals, LL-37 is the only member of the cathelicidin family that is expressed in humans and has shown a broad spectrum of activity against both gram-positive and gram-negative bacteria, as 
well as various viruses and fungi (Bals et al. 2003; Bucki et al. 2010). It is produced mainly by leukocytes, epithelial cells and mucosal cells where it is stored in specific granules (Scott et al. 2002; Steinstraesser et al. 2009). In humans, LL-37, along with other cationic peptides, prevent infection at a whole host of body sites, such as in pulmonary and digestive systems, salivary glands, skin and ocular surfaces, as well as others (Bucki et al. 2010). LL37 assumes an amphiphatic $\alpha$-helical conformation that in its original state in neutrophils is $17 \mathrm{kDa}$ in size. Once processed to the mature peptide it is $5 \mathrm{kDa}$ in size, which is why cathelicidins may be categorized as an antimicrobial protein, as well as a peptide (Boman 1995; Zanetti et al. 1995).

Defensins are a family of closely related, cationic antimicrobial peptides comprised of 29-45 amino acid residues. Six conserved cysteine residues are a characteristic feature of defensins that form three intramolecular disulfide bridges between the amino and carboxyl terminal regions of the peptide. This creates a cyclic, triplestranded, amphiphatic $\beta$-sheet structure. These three disulfide bridges serve to stabilize its $\beta$-sheet structure and increase its resistance to proteolysis (Campopiano et al. 2004; Diamond et al. 2009). Defensins can be divided into $\alpha$ - and $\beta$-defensins, which are very similar in their three dimensional (3D) structure and in function. The differences between these two groups are (1) the fact that the $\beta$-defensins tend to be slightly larger, and some may have modified termini, and (2) linkage of the cysteine residues (Boman 2003). The $\alpha$-defensins are produced constitutively and do not seem to require induction, however, most $\beta$-defensins that have been described are inducible (Diamond et al. 1991; Boman 2003). The $\alpha$-defensins, which have been 
studied in humans (Selsted et al. 1985), monkeys (Selsted 2004) and rodents (Ayabe et al. 2000; Ayabe et al. 2004), are found in abundance in neutrophils, macrophages and paneth cells of the small intestine (Ouellette et al. 1996; Ganz et al. 1998). They seem to have evolved to work inside the phagosome, where their propeptides are processed in the granule. These defensins are sequestered in the granules as their natural cytotoxicity could hurt the host. The $\beta$-defensins have signal peptides but no propeptides and they seem to be produced by the epithelial cells, protecting the mucosa both in the lungs and along the digestive tract (Bevins et al. 1999).

Another group that belongs to the defensin family is the $\theta$-defensin, which are small, circular molecules, the product of two separate genes; each produces two separate defensin molecules which are linked covalently (Tang et al. 1999). The $\theta-$ defensins differ from the $\alpha$ - and $\beta$-defensins in that they have a double-stranded $\beta$ sheet and have only been found in primates (Tang et al. 1999; Boman 2003).

Magainins belong to a large family of amphibian amphiphatic $\alpha$-helical antimicrobial peptides. They are usually 23 amino acid residues long and were originally isolated from the African clawed tree frog, Xenopus laevis, following observations of their continued good health after being surgically altered and left to recover under non-sterile conditions (Zasloff 1987). Magainins have been shown to have a broad spectrum of activity against gram-negative and gram-positive bacteria and fungi, and are known to reduce inflammation and promote wound healing (Zasloff 1987; Zairi et al. 2009). They also possess a potent spermicidal activity against human sperm, as well as being very effective against sexually transmitted pathogens, making 
them prime candidates for exploration as spermicides (Zasloff et al. 1988; Reddy et al. 1996).

Antimicrobial peptides are also found in multiple invertebrate animals such as the penaeid shrimp (Destoumieux et al. 1997; Tassanakajon et al. 2010) and horseshoe crab (Schnapp et al. 1996). In the penaeid shrimp there are three cationic peptide families, the penaeidins (Destoumieux et al. 1997), crustins (Relf et al. 1999), and antilipopolysaccharide factors (ALFs). These peptides are comprised of many different isoforms and have shown activity against a variety of bacteria and fungi (reviewed in Tassanakajon et al. 2010). They are synthesized primarily in the hemocytes and are released in response to infection (Munoz et al. 2002).

Not to be forgotten, plants also produce their own antimicrobial peptides in a wide range of tissues, and express significant antimicrobial potency (Garcia-Olmedo et al. 1998). Thionin, the first plant peptide reported to have activity against plant pathogens, has been shown to alter pathogen cell membrane permeability (Fernandez de Caleya et al. 1972; Castagnaro et al. 1992). Several families of cysteine-rich peptides have been characterized, including defensins, lipid transfer proteins (LTPS), heveintype peptides and knottin-type peptides (reviewed in Kim et al. 2009), from plants.

\section{Characterization of Antimicrobial Peptides}

Boman $(1998,2003)$ has classified antimicrobial peptides, small amphiphatic peptides usually between 15 and 45 amino acid residues, on the basis of their physicochemical characteristics (Boman 1998, 2003). They are further divided into five subcategories on the basis of their amino acid composition and primary structure: 
(1) anionic peptides, (2) linear amphiphatic $\alpha$-helical peptides, (3) cationic peptides enriched for specific amino acids, (4) peptide fragments, and (5) peptides with cysteines that form intramolecular bonds (Boman 2000; Brogden 2005; Diamond et al. 2009). Details of the five subcategories are as follows:

1) Anionic peptides. Anionic peptides are present in surfactant extracts, bronchoalveolar lavage fluid, and airway epithelial cells. They require zinc as a cofactor for activity and are active against both gram-positive and gramnegative bacteria. Examples include dermcidin in humans and maximin $\mathrm{H} 5$ from amphibians (Brogden 2005).

2) Linear amphiphatic $\alpha$-helical peptides. This subgroup is the most diverse and contains about 290 linear cationic $\alpha$-helical peptides that tend to be less than 40 amino acid residues in length and possess a three dimensional structure with a kink or hinge in the middle. These molecules adopt an $\alpha$-helical secondary structure when in contact with membranes, but are disordered in aqueous solution (Diamond et al. 2009). Examples of these peptides include the cecropins (Steiner et al. 1981), magainin (Zasloff 1987), pleurocidin from winter flounder (Cole et al. 1997) and melittin from bee venom (Fennell et al. 1968).

3) Cationic peptides enriched for specific amino acids. This group contains approximately 44 peptides, all of which are linear in shape and are enriched in specific amino acids. They lack cysteines residues, which makes them very flexible and fluid in solution. Examples include the bactenecins and prolinearginine-rich peptide (PR-39), both of which are rich in proline and arginine; 
proline-rich abaecin from bees, and indolicidin from cattle, which is rich in tryptophan (Brogden 2005).

4) Peptide fragments. This fourth group is comprised of charged peptides that are fragments of larger proteins. For example, lactoferricin (mentioned earlier) is a peptide derived from the digested $\mathrm{N}$-terminal portion of lactoferrin (Bellamy et al. 1993). Similarly, cathelicidins (also mentioned earlier) are peptides which are found at the $\mathrm{C}$-terminus of precursors whose $\mathrm{N}$-termini share a homology with the porcine serine protease known as cathelin (Zanetti et al. 1995;

Diamond et al. 2009). Also in this group are peptides derived from oxygenbinding proteins, such as hemacyanin and hemoglobin derived peptides (Vizioli et al. 2002).

5) Peptides with intramolecular cysteine bonds. This final group is composed of roughly 380 members that all contain conserved 6-cysteine residue motifs forming intramolecular disulfide bonds and $\beta$-sheets (Brogden 2005). This defensin group is an extremely diverse group which may have originated in prokaryotes (Zhu 2007). This group has diverged into plant defensins, arthropod defensins and the $\beta$-defensins found in birds, reptiles and mammals (Wong et al. 2007; Diamond et al. 2009; Wong et al. 2009). It includes the $\theta$ defensins, which seem to have mutated from the $\alpha$-defensins, which in turn originally diverged from the $\beta$-defensins (Selsted 2004). Similar to the defensins is a liver-specific peptide, hepcidin, which is also cysteine rich, with two $\beta$ - 
sheets. Hepcidin exhibits both antimicrobial activity and iron-regulatory activity (Ganz 2006).

More recently, additional categories have been informally added to include newly discovered proteins and proteins with previously defined functions to which antimicrobial activity has been newly ascribed. One group is the aromatic dipeptides, which comprise low molecular weight compounds isolated from dipteran larvae (e.g. N$\beta$-alanyl-5-S-glutathionyl-3,4-dihydroxyphenylalanine and $p$-hydroxycinnamaldehyde) (Vizioli et al. 2002).

Mechanism of Action of Antimicrobial Peptides

Most antimicrobials are cationic peptides, whose positive charge provides some selectivity towards negatively charged microbial cell outer membranes and cytoplasmic membranes. This specificity allows for differentiation between the microbial cells and host cells, and reduces cytotoxicity to host cells because their cell membrane invariably contains a higher percentage of cholesterol than bacterial cells (Diamond et al. 2009). The precise mechanism of action of antimicrobial peptides has been well studied, but still not completely understood. Their cationic charge leads to a high degree of potency in their antimicrobial activities. This is because of the presence of multiple lysine and arginine residues, a large portion of hydrophobic residues (50\% or higher) and amphipathicity (Zasloff 1987; Hill et al. 1991; Park et al. 2000). Methods such as fluorescent dye release in model membrane systems (Ladokhin et al. 1997), ion channel formation (Christensen et al. 1988) and measurement of secondary 
structure (Wu et al. 1995; Bechinger et al. 2004; Lee et al. 2004) have helped to discern several proposed mechanisms of activity.

It is generally accepted that antimicrobial peptide-mediated killing of microbes occurs through membrane permeation, but not exclusively. For example, non-membrane disruptive methods have also been observed (Diamond et al. 2009). The ability to kill bacteria via pore formation requires three key steps: binding to the bacterial membrane, aggregation within the membrane, and formation of channels. The channel formation leads to cell death via leakage of internal cell contents. In order to carry out this process, an antimicrobial peptide (often referred to as AMP) must cross the negatively charged outer membrane of gram-negative bacteria which contains lipopolysaccharides (LPS), or the outer wall of gram-positive bacteria, which contains acid polysaccharides (Hancock et al. 1997; Palffy et al. 2009). The three most established pore forming models are the barrel-stave pore, the thoroidal pore, and the carpet model (Lehrer et al. 1989; Hancock 1997; Oren et al. 1998; Palffy et al. 2009). In the barrel-stave pore model, AMP binds to the negatively charged membrane to form dimers or multimers. Multimers of AMP cross the cell membrane so that the hydrophobic region is facing the lipid bilayer, and the hydrophilic region is facing the lumen of the pore. The assembled peptides form barrel-like channels resembling staves (Ben-Efraim et al. 1997). The thoroidal pore model shares a common mechanism with the barrel-stave pore model. However, in this model, the AMP forms a monolayer by connecting the outer and inner lipid layers in the pore (Lehrer 1989; Hancock 1997; Oren et al. 1998; Palffy et al. 2009). The carpet model has peptides 
covering the outer surface of the membrane, thus the peptides act as detergents, disrupting the membrane bilayer after reaching a threshold concentration. The pores are formed from micelle-like units (Oren et al. 1998; Palffy et al. 2009).

Additional models have been suggested that are specific to one or other AMP. This includes molecular electroporation, where some peptides are able to create electrostatic potentials across the bilayer sufficient for pore generation (Chan et al. 2006; Palffy et al. 2009). Other methods involve peptides binding to the endotoxin moieties of bacterial LPS (such as defensins and cathelicidins) (Bals 2000; Palffy et al. 2009). Some AMPs inhibit DNA synthesis, protein synthesis, or both (Gennaro et al. 2002; Boman 2003). Histatin targets the mitochondria of fungal pathogens (Tsai et al. 1998).

Histones historically have been associated with DNA stabilization, playing a crucial role in the packaging of DNA, thereby ensuring efficient replication and segregation of the chromosomes. Histone gene transcription is coordinated with the cell cycle and regulated by cyclins and D-type cyclins, CDKs (Ewen 2000). They are divided into two functional types: 1) core histones, which are comprised of histones $\mathrm{H} 2 \mathrm{~A}, \mathrm{H} 2 \mathrm{~B}, \mathrm{H} 3$ and $\mathrm{H} 4$, and together form an octameric complex (about 146 basepairs of DNA) to create the nucleosome; and 2) linker histones, $\mathrm{H} 1$, which seal loops of DNA that enter and leave nucleosomes and condense these structures into compact, higher order fibers. The structure of core histones does not differ much among species. The H1 histones, however, are the largest and most heterogeneous family of histones and much more varied (Smith 1991; Hiemstra et al. 1993). These proteins show structural variations 
not only among but also within species (Kawasaki et al. 2008). These variations can be explained by any number of post-translational modifications such as acetylation, methylation, poly-(ADP ribosyl)ation, ubiquination, sumoylation and perhaps even phosphorylation (Parseghian et al. 2006).

Despite being historically associated with DNA packaging, histones are not confined to the nucleus. It has been found that after biosynthesis in the cytosol by free ribosomes, a limited amount of histone is accumulated. These are imported to the nucleus via karyopherins (also known as importins), while the excess (unacetylated) histones accumulate in the cytoplasm, especially in rapidly regenerating or transcriptionally active cells (Zlatanova et al. 1990; Watson et al. 1995; Chang et al. 1997; Augusto LA 2003). Secretion of cytoplasmic histone extracellularly has been observed (Watabe et al. 1996; Brix et al. 1998; Augusto LA 2003), and extracellular histones are released from apoptotic cells (Schwartz et al. 1993). Histones may also be found on the cell surface, as evidenced by binding of sulfated polysaccharide D2S to the surface of T-cells. Using ligand-studies and immunoblotting techniques, histone $\mathrm{H} 2$ was found to be the ligand on the surface of the T-cell (Watson et al. 1995). Consequently, histones are quite ubiquitous, having been shown to be present in the cell nucleus, cytosol, cell membrane, and extracellular environment (Parseghian et al. 2006).

There are several possible explanations as to why histones, usually associated with DNA stabilization, have shown antimicrobial activity. It has been suggested that a structural motif of histone, which strongly binds to DNA, may be used as an 
antimicrobial peptide to bind to the cell membrane of invading microorganisms (Park et al. 1996). Studies (Frank et al. 1990; Lehrer et al. 1992) have shown that one main biological action of antimicrobial peptides such as defensins and bactenecins involve lipid and membrane binding. Since a single biologically active compound can have more than one kind of macromolecule-binding activities, it can be hypothesized that the isolated peptides adopted the histone-like structure to bind strongly to lipids of cell membranes, which is necessary for antimicrobial activity (Frank et al. 1990; Lehrer et al. 1992; Park et al. 1996).

Other studies have revealed yet another function of histones. Researchers have observed that histones have a remarkably high affinity for LPS. In lung epithelial cell lines they found that the most efficient LPS binding proteins were two histones, H2A.1 and $\mathrm{H} 4$. However, to be effective, the entire 3D structure of the histone is required to be intact (Augusto et al, 2003). It has also been reported that the major LPS-binding protein in the brain is an isoform of histone $\mathrm{H} 1$, predominantly located at the neuronal cell surface (Bolton et al. 1997).

\section{Histones as Novel Antimicrobial Peptides}

In leukocytes, antimicrobial peptides are sequestered in granules. In response to an infection, the leukocyte is activated and, following phagocytosis of microorganisms, its cell content degranulates releasing hydrolyzing enzymes, antimicrobial peptides and other effector molecules to the infection site. As these granules contain acid soluble enzymes such as lysozyme, ribonucleases and deoxyribonucleases; the nature of antimicrobial substances was difficult to distinguish from the histones and 
protamines found in the nuclei (Zeya et al. 1966; Isenberg 1979). Investigators have since been able to attribute antimicrobial activity specifically to histones and their related fragments, working independently or synergistically with each other and other peptides (Rose et al. 1998; Agerberth et al. 2000; Kim et al. 2000; Patrzykat et al. 2001; Kawasaki et al. 2008). Histones that possess such broad spectrum antimicrobial activity have been found in shrimp (Patat et al. 2004), teleost fish (Robinette et al. 1998; Noga et al. 2001; Richards et al. 2001; Fernandes et al. 2002; Bergsson et al. 2005), frog (Kawasaki et al. 2003), chicken (Silphaduang et al. 2006; Li et al. 2007) and mammals (Hiemstra et al. 1993; Rose et al. 1998; Kim et al. 2002; Howell et al. 2003; Jacobsen et al. 2005) (reviewed in Kawasaki and Iwamuro 2008).

Purified histone $\mathrm{H} 1$ was found to be expressed in the cytoplasm of intestinal villus epithelial cells, and upon detachment of the epithelial cell, was released as the cell underwent programmed cell death (i.e., apoptosis) (Rose et al. 1998). It was suggested that $\mathrm{H} 1$ may protect villus epithelial cells against penetration by microorganisms (Rose et al. 1998). Immunohistochemistry studies show that $\mathrm{H} 1$ is found in the nucleus, affording the cell continued protection even after the microorganism had penetrated through the cell membrane (Rose et al. 1998). In flounder, there is additional evidence that synthesized histone $\mathrm{H} 1$ may work synergistically with flounder pleurocidin to potentiate and enhance its antibiotic effects against fish pathogens (Patrzykat et al. 2001). In the chicken, full length histone $\mathrm{H} 1$, as well as $\mathrm{H} 2 \mathrm{~B}$, were purified from extracts of the ovary and oviduct, and were active against both gram negative and gram positive bacteria, but a high salt 
concentration was required for histone $\mathrm{H} 1$ to express the activity against the gram negative bacteria (Silphaduang et al. 2006). A histone $\mathrm{H} 1$ fragment has been isolated from skin secretions of rainbow trout, termed oncorhyncin II, with broad spectrum antimicrobial activity against not only bacteria, but also fungi (Fernandes et al. 2004).

Histone $\mathrm{H} 2 \mathrm{~A}$ is the best studied member of this family of proteins, and the full length protein has been isolated from human placenta (Kim et al. 2002), chicken liver (Li et al. 2007), and rainbow trout (Fernandes et al. 2002). Histone H2A fragment was isolated from gastric tissue of the Asian toad and results of the study provided further evidence of the association of histones with cells undergoing apoptosis (Park et al. 1996). The toad histone H2A fragment was found to be a precursor of Buforin I, a potent 39 amino acid antimicrobial peptide. These instances provided further evidence that histones play a major role in host defense (Park et al. 1996, 2000). By substituting an amino acid on Buforin I, a H2A-derived antimicrobial peptide was generated that showed a broad-spectrum of activity against several microorganisms, but did not kill microbes by cell lysis. This modified antimicrobial agent had a strong affinity for DNA and RNA, suggesting that it targeted intracellular substances like nucleic acids (Park et al. 2000). This observation indicates an enormous potential for the production of a new class of antibiotics (Barra et al. 1998; Boman 1998). Two other forms of histone H2A-related peptides (fragments) have been found in the skin mucus of fish, Parasin I, from the skin mucus of a wounded catfish (Park et al. 1998) and hipposin, from the Atlantic halibut (Birkemo et al. 2003). 
Histone $\mathrm{H} 2 \mathrm{~B}$ was first isolated from the cytoplasm of mouse (murine) macrophage cell lines, RAW264.7 and J774A.1 (Hiemstra et al. 1993). It has also been isolated from colonic epithelial cells in tandem with H1 (Howell et al. 2003). Calf intestinal H2B was found to have anti-parasitic activity, similar to the histone H1-like protein isolated from the skin, gill, and spleen extracts of rainbow trout and sunshine bass (Noga et al. 2001). Histone H2B fragments have been isolated from extracts of human blister wound fluid, which displayed very high activity against gram positive bacteria (Frohm et al. 1996).

There are few reports of the antimicrobial activity of histones $\mathrm{H} 3$ and $\mathrm{H} 4$, not because they are less studied, but because of their pattern of co-purifiying with other histones like histone H2B (Kawasaki et al. 2008). Recently, however, investigators have reported on the antimicrobial activity of histone $\mathrm{H} 4$ (Lee et al. 2009). A novel histone antimicrobial peptide, synthesized from buforin II, shows homology to histone H3 with broad spectrum antimicrobial activity (Tsao et al. 2009).

Augusto et al. (2003) observed that the affinity of histones for bacterial lipopolysaccharides (LPS) is higher than that of polymyxin B, an antibiotic known to block several biological activities of LPS. This affinity indicates that the therapeutic potential of histone analogues may (as with other LPS-binding molecules) reduce bacterial growth, facilitate bacterial opsonization, or directly block the interaction of LPS with host pro-inflammatory pathways. 


\section{Immunomodulatory Effects of Antimicrobial Peptides}

The synthesis of enteric defensins in human fetal tissue starts 13.5-17 weeks after gestation, and it has been shown that LL37 and members of the defensin family are present in amniotic fluid (Mallow et al. 1996; Yoshio et al. 2004). It was once the prevailing thought that an antimicrobial peptide's only function was as a microbicidal agent. It has since come to light that this is only one aspect of these astonishing molecules. Antimicrobial peptides (AMPs) have the capacity to regulate epithelial cell proliferation, enhance wound healing (Frohm et al. 1996), inhibit or induce proinflammatory cytokines (Nagaoka et al. 2001), take part in angiogenic and antiangiogenic processes (Li et al. 2000), stimulate chemokine production (Bowdish et al. 2005), facilitate chemotaxis of various leukocytes (Huang et al. 1997), influence mast cell degranulation (Befus et al. 1999) and modulate host cell gene expression (Kelly et al. 2006). To the surprise of mainstream immunologists, these relatively obscure peptides have been implicated in helping to modulate adaptive immune function. A number of studies have reported that co-administering antimicrobial peptides with relatively benign antigens results in the enhancement of the host's cell mediated and humoral immune responses to these antigens (Lillard et al. 1999; Tani et al. 2000; Brogden et al. 2003). These findings strongly implicate $\alpha$-defensins as immune adjuvants that promote T cell-dependent cellular immunity as well as antigen-specific immunoglobulin production (Lillard et al. 1999). Furthermore, it has been postulated that antimicrobial peptides may be modulating lymphocyte responses, modifying cytokine expression during antigen presentation and possibly causing maturation of immature dendritic cells 
by inducing co-stimulatory molecules, resulting in more effective antigen presentation and subsequent robust T cell activation (Funderburg et al. 2007; Diamond et al. 2009).

Peptides have also been shown to act as cofactors to lower lethality of a hyperinflammatory response (Steinstraesser et al. 2009). Endotoxin, found on the outer layer of gram-negative bacteria, is recognized as harmful and activates the innate immune system. In some cases, antibiotics can cause endotoxin release which can be neutralized by the antimicrobial peptide LL-37, thus inhibiting the production of pro-inflammatory cytokines such as tumor necrosis factor- $\alpha$ and IL-6 (Zanetti et al. 1995; Scott et al. 2002).

\section{Significance of Antimicrobial Peptides}

The number of known antimicrobial peptides is rapidly increasing. So far over 1,220 peptides have been characterized, including over 940 peptides from eukaryotic organisms (Steinstraesser et al. 2009). There are three databases that list antimicrobial peptides. These are the ANTIMIC, AMPer and APD2 (Brahmachary et al. 2004; Fjell et al. 2007; Wang et al. 2009) databases. AMPs differ in their structure, physicochemical characteristics and biological function. They also differ in their mechanisms of action, as well as their antimicrobial activities (non-cationic peptides tend to have weaker bactericidal activity than do cationic peptides) (Vizioli et al. 2002). It has been shown that antimicrobial peptides can kill susceptible bacteria in vitro at concentrations up to $4 \mu \mathrm{g} / \mathrm{ml}$ (Hancock et al. 1998); beyond that concentration there is the risk of host cell toxicity. Antimicrobial peptides have been shown to play a 
significant role in the prevention of disease (Hancock et al. 1998; Rivas-Santiago et al. 2009). There are scores of studies on the susceptibility to infectious disease on the basis of the level of antimicrobial peptide production by the host. During primary infection, the level of inflammation is directly related to the immune response mounted by the host. Recruitment of inflammatory cells by chemokines and production of pro-inflammatory cytokines and release of antimicrobial peptides will determine the outcome of infection (Rivas-Santiago et al. 2009). Antimicrobial peptides play key roles in infectious diseases of the skin. In atopic dermatitis, viral and bacterial infections complicate successful therapy as they can lead to cutaneous inflammation. It has been shown that these patients have a significantly lower production of dermcidin 1 than do healthy subjects (Schittek et al. 2001; RivasSantiago et al. 2009). Another skin condition, atopic eczema, is associated with decreased expression of human $\beta$-defensin-2 (HBD-2), HBD-3 and LL-37, which can lead to skin infections with Staphylococcus aureus (Ong et al. 2002; Nomura et al. 2003; Rivas-Santiago et al. 2009). Psoriasis is another example of human inflammatory skin disease associated with abnormal antimicrobial peptide expression. Cathelicidin is increased in lesional skin in these patients (Ong et al. 2002; Rivas-Santiago et al. 2009). These studies have important implications on the use of cathelicidins and others in skin infection control. Clinical applications of antimicrobial peptides in treating burn wounds have also been examined. In one study, transient cutaneous adenoviral delivery of LL-37 resulted in significant bacterial inhibition that might be a potential 
adjunct for wound treatment in the near future (Jacobsen et al. 2005; Rivas-Santiago et al. 2009).

Antimicrobial peptides have also been studied in gastrointestinal infections as the healthy intestinal tract is characterized by a sensitive balance of host antimicrobial peptides and intestinal microbes. For example in some African adults, low $\alpha$-defensin expression appears to be associated with a higher risk of infectious diarrhea (Kelly et al. 2006; Rivas-Santiago et al. 2009).

Members of the three main peptide families are found in the oral cavity: LL-37, $\alpha-$ and $\beta$-defensins and peptides with an unusually high proportion of specific amino acids, such as histatins (Dale et al. 2006; Rivas-Santiago et al. 2009). In Morbus Kostmann, a genetic disorder, patients experience frequent oral bacterial infections and severe periodontal disease, which correlate with a deficiency in the production of cathelicidin peptide LL-37 and $\alpha$-and $\beta$-defensins (Dale et al. 2006; Rivas-Santiago et al. 2009).

Systemic infectious diseases that are caused by viruses such as the HIV virus have been shown to be vulnerable to $\beta$-defensins as they seem to compete for the same chemokine receptor, so the virus is unable to enter the cell. The $\beta$-defensin then seems to confer a protective response to the host (Garzino-Demo 2007; Rivas-Santiago et al. 2009).

Lung infections caused by infiltration and growth of Mycobacterium tuberculosis have been shown to be marginally controlled by the presence of high levels of 
cathelicidin, LL-37, in epithelial cells, neutrophils, and alveolar macrophages (RivasSantiago et al. 2006).

The studies mentioned above all suggest there is efficacy in the possible use of certain antimicrobial peptides in therapy as an alternative treatment option in the management of infectious diseases (Rivas-Santiago et al. 2009).

Significance of Elasmobranchi as a Model System

In the rapidly evolving area of inquiry into the nature of antimicrobial peptides, there are many questions that still exist. These include:

- How ubiquitous are these proteins and peptides in nature?

- What other animals express these proteins and peptides?

- What are their mechanisms of action?

- How have these proteins and peptides evolved in the development of vertebrate and invertebrate immunity?

There is a need for more study in this area, using varied animal systems. The nurse shark, Ginglymostoma cirratum, which belongs to the class Elasmobranchi, is a basal vertebrate with a fully developed innate and adaptive immune system. This basal animal is strategically placed in the phylogenetic lineage and is a good model to study unresolved questions regarding antimicrobial peptides in primitive vertebrates. The nurse shark's natural antibodies, spontaneous cytotoxicity, and complement have been studied, and are believed to work in concert to form an immunosurveillance system seeking out new antigens (Rudikoff et al. 1970; Clem et al. 1982; Pettey et al. 
1983; Smith et al. 1986; Flajnik 1994; Parham 1995). In addition, innate system components such as antibacterial proteins/peptides and other antimicrobial substances may form the basis of innate immunity necessary to maintain a healthy animal, particularly during times of stress. Nurse sharks inhabit tropical and subtropical waters on the continental shelf, and can be found along the Western and Eastern Atlantic coasts; along the islands of the Caribbean; as well as the Eastern Pacific coast. Nurse sharks have been known to inhabit polluted waters, as they are bottom dwellers of shallow warm waters (Fange et al. 1981). In this environment the nurse shark is at a greater risk to infectious agents than animals that inhabit deeper and more open waters (which are less likely to be polluted), and runs a greater risk of physical trauma as a result of man's intrusion into its habitat (Reif 1978). For these reasons, an efficient immune system with innate and adaptive immune mechanisms is essential for its survival. Because of the critical role of innate immunity in the development and survival of this species, Ginglymostoma cirratum makes a good animal model to study, aided by the fact that it is one of a few shark species that can be successfully maintained in captivity for long periods (Clark 1963). The nurse shark has a less well developed adaptive immune system compared to mammals, therefore it would be expected that a non-specific antibacterial response to pathogens would play a more significant role when mounting an immediate immune response.

\section{Goals and Hypothesis}

This study was undertaken to test the hypothesis that in addition to lysozyme, nurse shark peripheral blood leukocytes possess antibacterial factors that include histone 
fragments. The specific goal was to demonstrate antibacterial activity in crude leukocyte lysates, against a target bacterium, Planococcus citreus, and to determine its mode of action. 


\section{MATERIALS AND METHODS}

\section{A. MATERIALS}

Details of the buffers, reagents, solutions, culture media preparation, protocols for the preparation of acrylamide gels, western blot buffers and antisera preparation and concentration can be found in Appendix I.

\section{B. METHODS}

\section{Blood Collection}

Initially several (8-10) nurse sharks (Ginglymostoma cirratum), males and females, ranging in size from 1.5 -2 meters (5-7 feet) were maintained in a seawater channel at the Keys Marine Laboratory, Long Key, Florida Keys. Following the loss of all animals in a hurricane, a newly acquired, single female animal, about 1.2 meters ( $4 \frac{1}{2}$ feet), was maintained and bled at 6-8 week intervals to obtain $60 \mathrm{ml}$ of blood. The shark was anesthetized in a rectangular tank of seawater containing $1 \mathrm{ppm}$ 3-aminobenzoic acid ethyl ester (methanesulfonate salt). The anesthetized shark was bled by placing it in a horizontal position on its back, on a clean surface, and withdrawing blood with a 20 gauge, $1 \frac{1}{2}$ inch needle from the caudal vein using a $60 \mathrm{ml}$ syringe. The animal was then returned to the channel and manually moved back and forth through the water until normal gill respiration returned before release. This work was conducted with institutional IACUC approval. 


\section{Preparation of Cytospins}

Blood smears were prepared from a nurse shark leukocyte-enriched suspension to evaluate cell morphology and to acquire differential counts. Nurse shark heparinized whole blood (1000 units $/ \mathrm{ml}$ ) was left to settle for 2 hours. The buffy coat was removed (with a thin layer of erythrocytes attached) and spun at $435 \mathrm{x} / \mathrm{g}(1240 \mathrm{rpm})$ for 10 minutes $(\mathrm{min})$ at $15^{\circ} \mathrm{C}$. The leukocyte enriched pellet was resuspended and washed with sRPMI at $435 \mathrm{x} / \mathrm{g}(1240 \mathrm{rpm})$ for $10 \mathrm{~min}$ at $15^{\circ} \mathrm{C}$. The wash was decanted and the pellet was resuspended to $1 \times 10^{5}$ cells $/ \mathrm{ml} .250 \mu$ of the cell suspension was loaded onto a cytospin chamber loaded with a poly-L-Lysine coated microscope slide and centrifuged in a cytocentrifuge (Cytopro, Wescor), at $250 \mathrm{x} / \mathrm{g}$ (1200 rpm) for $3 \mathrm{~min}$ at room temperature. The leukocyte enriched monolayer was air-dried and stained with leukostat stain for morphological identification of nurse shark peripheral blood cell populations.

\section{Isolation of Peripheral Blood Leukocytes}

Freshly collected nurse shark blood was aliquoted in $15 \mathrm{ml}$ polypropylene, screw cap tubes containing anticoagulant. Blood $(9 \mathrm{ml})$ was added to $1 \mathrm{ml}$ of $3.8 \%$ trisodium citrate in shark RPMI media (0.35M urea, $0.2 \mathrm{M} \mathrm{NaCl}, \mathrm{pH} 7.4)$, to give a final concentration of $0.38 \%$ anticoagulant. The tube was inverted gently several times until complete mixing was achieved, and blood samples were transported on ice to the lab for processing. 
Anticoagulated blood was diluted with an equal volume of shark RPMI. Using a long pasteur pipette, $24 \mathrm{ml}$ of the diluted blood sample was withdrawn and layered carefully onto the surface of $18 \mathrm{ml}$ of a gradient mixture consisting of two parts Lymphocyte Separation Media, LSM (Sigma, MO), and one part physiological saline $(0.15 \mathrm{M} \mathrm{NaCl})$ in a $50 \mathrm{ml}$ centrifuge tube. The sample was centrifuged at $435 \mathrm{x} / \mathrm{g}(1240$ rpm) for $30 \mathrm{~min}$ at $15^{\circ} \mathrm{C}$ in a Beckman GPR centrifuge (brake off). A small volume of whole blood was retained to determine the total white cell count and differential counts. Following centrifugation, the cloudy interface layer along with the thin buffy coat layer present on the surface of sedimented erythrocytes was removed and transferred to a sterile $15 \mathrm{ml}$ tube. The harvested leukocytes were separated by centrifugation at $435 \mathrm{x} / \mathrm{g}(1240 \mathrm{rpm})$ for $20 \mathrm{~min}$ at $15^{\circ} \mathrm{C}$. Any remaining contaminating erythrocytes in the pellet were lysed by hypotonic lysis; the pellet was resuspended in approximately 5 times its volume in $0.2 \% \mathrm{NaCl}$ by inverting several times to resuspend cells completely (this permitted all cells to be lysed by the hypotonic lysing solution). Then an equal volume of $2.5 \% \mathrm{NaCl}$ was added to the solution of $0.2 \% \mathrm{NaCl}$ solution to neutralize the effect of the lysing solution. The suspension was centrifuged at $435 \mathrm{x} / \mathrm{g}$ (1240 rpm) for $15 \mathrm{~min}$ at $10^{\circ} \mathrm{C}$ and the supernatant discarded. The pellet of isolated leukocytes was resuspended in 1-2 $\mathrm{ml}$ of $0.25 \mathrm{M} \mathrm{NaCl}$, isotonic for shark leukocytes. Using a small aliquot of the leukocyte suspension, a total cell count was determined manually using a haemocytometer and used to calculate the leukocyte yield. A viability test was also performed (employing the trypan blue exclusion test) to confirm 
that cells were viable and intact and not 'leaking' intracellular contents. The cell suspension was stored at $-20^{\circ} \mathrm{C}$ until ready to use.

\section{Trypan Blue Exclusion Test}

The trypan blue exclusion test was used to determine the viability of shark cells because live, viable cells with intact cell membranes, exclude certain dyes, such as trypan blue. For experimental purposes a cell viability of $95 \%$ or higher was deemed optimal for biological assays. A $10 \mu$ l aliquot of cell suspension was diluted in $1 \mathrm{ml}$ $0.25 \mathrm{M} \mathrm{NaCl}$ and $10 \mu \mathrm{l}$ removed and mixed 1:2 with cell viability reagent. After $3 \mathrm{~min}$ incubation at room temperature (RT), a drop of suspension was applied to a haemocytometer and viewed under the 40x objective lens. The stained (nonviable) and unstained (viable) cells were counted separately up to a total of 200 cells. The percent viability was calculated as follows:

Percent viable cells $=\frac{\# \text { viable cells per } 200 \text { cells }}{200 \text { cells }} \times 100$

\section{Preparation of Leukocyte Lysates}

Cell lysates were prepared from the frozen suspended pellets (isolated using LSM) by first freezing and thawing to facilitate lysis. The cell pellets were thawed at room temperature, refrozen at $-80^{\circ} \mathrm{C}$, and then thawed again. Once thawed, the cell suspension was held on ice. The repeated freeze-thaw treatment facilitated subsequent disruption of cells by mechanical shearing using a glass homogenizer and/or ultrasonic disruption in a sonicator (Sonicator 3000, Misonix). For sonication of 
cell pellet, $0.25 \mathrm{M} \mathrm{NaCl}$ was added to the cell suspension. A $2 \mathrm{ml}$ cell suspension was placed in a $15 \mathrm{ml}$ screw cap tube, and immersed in a beaker filled with ice and sonicated at 18-27 watts for 10 min with 1 min pulses and 2 min rest periods in between pulses. Efficiency of disruption was confirmed by microscopic examination of the sonicated suspension for complete disruption of cells with intracellular contents expelled. The resulting cell lysate was collected by centrifuged for $90 \mathrm{~min}$ at $21,000 \mathrm{xg}$ at $7^{\circ} \mathrm{C}$ (Micromaxx FF, IEC) to pellet the debris. The cell lysate supernatant (CLS) was removed and stored at $-20^{\circ} \mathrm{C}$ as small aliquots of $2 \mathrm{ml}$ in eppendorf tubes. Protein concentration of each leukocyte lysate preparation was determined using the BCA colorimetric protein assay protocol (Pierce, IL).

\section{Concentration and Dialysis of Lysates}

Each cell lysate supernatant was thawed and clarified by centrifugation for $5 \mathrm{~min}$ at $1000 \times$ g (Micromaxx FF, IEC) to sediment any precipitated material which may have formed as a result of freezing. Lyophilization was used to concentrate samples.

Dialysis: For chromatography, lysate samples were dialyzed against the column equilibration buffer using Spectra Por Dialysis Tubing with a 3000-D cutoff. Dialysis was carried out for up to 8 hours at $4^{\circ} \mathrm{C}$ with buffer changes every 2 hours (h). Lyophilization: Before being subjected to lyophilization, high salt samples (e.g., column fractions eluted at high salt) were first dialyzed (as per above). The thawed samples were placed in $50 \mathrm{ml}$ polypropylene tubes and freeze-dried (Freezedryer, 
Labconco) for 12-18 hours. The lyophilized samples were reconstituted in a small volume of $\mathrm{ddH}_{2} \mathrm{O}$ to obtain a 4-10 fold concentration of the sample.

\section{Detection and Quantitation of Antibacterial Activity}

Screening methods

(1) Lysoplate assay

The lysoplate assay was used as a screening method to assay for lysozyme (muramidase) activity. The lysoplate method was originally developed by Osserman and Lawlor (1966) and later modified by Manchenko (1994). A 0.12\% $(1.2 \mathrm{mg} / \mathrm{ml})$ stock suspension of lyophilized Micrococcus lysodeikticus cell walls in $0.06 \mathrm{M}$ phosphate buffer, $\mathrm{pH} 6.2$ was prepared and stored as $50 \mathrm{ml}$ aliquots at $4^{\circ} \mathrm{C}$. Lysoplates were set up by preparing an agarose lawn in 0.06M PB, pH 6.2, containing a suspension of Micrococcus lysodeikticus cell walls ( $0.06 \%$ final concentration). To prepare a lysoplate, the Micrococcus lysodeikticus cell wall suspension was removed from the cold and equilibrated to $55^{\circ} \mathrm{C}$ before being added to the agar medium.

To prepare the plates equal volumes ( $5 \mathrm{ml}$ each) of $2 \%$ agarose and $0.12 \%$ bacterial cell wall suspension, equilibrated to $55^{\circ} \mathrm{C}$ for one hour in a water bath, were gently mixed together to a final concentration of $1 \%$ agarose and $0.06 \%$ cell wall suspension, and poured into a square petri dish marked with a grid (Fisher Scientific, GA). Wells ( $3 \mathrm{~mm}$ diameter) were punched into the solidified agar at the 
center of each grid square using the sterile tip of a $3 \mathrm{~mm}$ diameter template cutter (ICN, OH). The cell lysate samples were thawed and kept on ice prior to the assay. Each well was filled with $5 \mu$ l of test sample. Negative controls consisted of distilled water, buffer or salt solutions, while chicken egg white lysozyme (final concentration $0.01 \mathrm{mg} / \mathrm{ml}$ ) was used as a positive control. Assays were set up in duplicate. Once sample material diffused from the well into the agar, the plates were inverted and incubated at $37^{\circ} \mathrm{C}$ for 24 hours. Plates were examined for zones of clearing (indicative of cell wall lysis) around the wells and the diameter of the zones (measured as an average size of duplicate tests) recorded. Lysozyme activity was calculated in arbitrary units, as follows. The diameter of the well ( $3 \mathrm{~mm}$ ) was subtracted from the diameter of the zone of clearing, and using the relationship of $0.1 \mathrm{~mm}$ diameter size equal to 1 unit (U) of enzyme activity (Lehrer et al. 1991) the enzymatic activity was estimated.

(2) Agar Diffusion assay

The agar diffusion assay was used as an initial screening method to detect antibacterial activity. The original protocol developed by Lehrer (1991) was modified. In place of marine broth an artificial seawater medium, enriched with peptone and yeast extract (Makemson et al. 1998) was used, which provided a clearer agar medium (minimal precipitation) and permitted sharper visualization of antibacterial activity. The supplemented sea water medium supported good growth of Planococcus citreus, used as the target bacterium in experiments. 
Planococcus citreus, a salt tolerant Gram positive coccus, was used as the target organism in the antibacterial assay to detect antibacterial activity of shark cell lysates. Stock cultures of $P$. citreus were maintained at $30^{\circ} \mathrm{C}$ on agar plates and slants of artificial sea water complete agar (SCA) and subcultured every other day. Stock cultures were stored at $4^{\circ} \mathrm{C}$. From a $48 \mathrm{~h}$ SCA plate culture, $P$. citreus was inoculated into $50 \mathrm{ml}$ artificial sea water complete broth (SCM) in a $125 \mathrm{ml}$ conical flask and grown to log phase for $6-8$ hours at $30^{\circ} \mathrm{C}$ in an incubator. A $5 \mathrm{ml}$ aliquot of broth culture was then removed and added to fresh medium $(50 \mathrm{ml})$ and incubated further for 8 hours at $30^{\circ} \mathrm{C}$. The broth culture was centrifuged (1085 x g for 5-7 $\mathrm{m}$ ) and the sedimented bacterial pellet was resuspended in SCM. For the radial diffusion assay, the resuspended bacterial pellet was washed twice with $3.2 \% \mathrm{NaCl}$ solution. The bacterial suspension was standardized to an $\mathrm{OD}_{580 \mathrm{~nm}}$ of 0.5 which corresponded to a bacterial count of approximately $10^{6} \mathrm{CFU} / \mathrm{ml}$. Before use in the agar diffusion assay, the agar stored in screw cap tubes was melted in a boiling waterbath (Tek-Bath, Tek-Pro), then cooled to $44^{\circ} \mathrm{C}$ in a water bath before addition of $100 \mu \mathrm{l}$ of the target organism $P$. citreus, $\left(10^{6}\right.$ cells $\left./ \mathrm{ml}\right)$, to the molten agar. The mixture was stirred carefully to evenly suspend the bacteria, poured into $10 \mathrm{~cm}$ sterile petri dishes, and allowed to solidify at room temperature. The assay plates were stored at room temperature and used within the hour to set up the acid-urea overlay assays. 
The $P$. citreus inoculum for microdilution growth assays was prepared as described above for the agar diffusion assays, however, the sedimented bacterial pellet was resuspended in SCM, and standardized to an OD $580 \mathrm{~nm}$ of 0.15 which corresponded to a bacterial concentration of approximately $2.5 \times 10^{4} \mathrm{CFU} / \mathrm{ml}$ (determined as above).

\section{Microdilution growth assay}

The agar diffusion assay was limited in sensitivity and only provided a rough estimate of the level of antibacterial activity. It was necessary to design an assay with increased sensitivity to detect antibacterial activity and which could be used to measure the level of activity. Since no such assay had been described for shark antibacterial proteins/peptides, an essential part of this study was to develop a microdilution growth assay. Initially the assay was developed using sea water complete broth (SCM) medium and Planococcus citreus as the target organism. The reaction mix for the assay consisted of $50 \mu \mathrm{l}$ of test sample (cell lysate supernatant), $75 \mu \mathrm{l}$ of $2 \times \mathrm{SCM}$ and $100 \mu \mathrm{l}$ of $\log$ phase $P$. citreus standardized to $2.5 \times 10^{4} \mathrm{CFU} / \mathrm{ml}$. The assay was set up in a polypropylene microwell plate (VWR, $P A)$ and each sample was set up in triplicate. The plates were mixed on a microplate shaker for $5 \mathrm{~min}$, and absorbance read at $\mathrm{OD}_{570 \mathrm{~nm}}$, which served as a $0 \mathrm{~h}$ reading $(\mathrm{t}=0)$. The plate was further incubated at $30^{\circ} \mathrm{C}$ for 12 hours and absorbance read again every two hours at $\mathrm{OD}_{570 \mathrm{~nm}}$. Extrapolating from the growth curve of $P$. citreus the end point of the assay was established at $12 \mathrm{~h}$ when maximum growth is obtained. Assays were set up in triplicate as follows, with each triplicate consisting of a medium control (225 $\mu$ l of $2 x$ 
SCM), culture control (50 $\mu \mathrm{l}$ of $1 \times$ SCM as diluent, $75 \mu \mathrm{l}$ of $2 \times \mathrm{SCM}$ and $100 \mu \mathrm{l}$ of log phase $P$. citreus), lysate control (50 $\mu$ l of cell lysate supernatant and $175 \mu$ l of $2 x$ SCM), and defensin control (50 $\mu \mathrm{l} \alpha$-defensin, HNP1 (25 $\mu \mathrm{g} / \mathrm{ml}), 75 \mu \mathrm{l}$ of 2 X SCM and $100 \mu \mathrm{l}$ of log phase $P$. citreus).

To determine optimal assay conditions for maximal sensitivity for detecting antibacterial activity, the assay was set up at varying incubation temperatures, $\mathrm{pH}$, and salinity, and using different cell densities of the $P$. citreus culture. Once conditions were optimized, the standard assay was routinely used to detect antibacterial activity in samples.

Optimal $\mathrm{pH}$ for detecting antibacterial activity was determined by setting up standard assays using assay medium adjusted to $\mathrm{pH}$ values of 4.0, 5.5, 6.5, 7.5 and 8.5. One volume of the sample was mixed with two volumes of the $\mathrm{pH}$ adjusted medium and $50 \mu \mathrm{l}$ was used to set up the standard assay using $\mathrm{pH}$-adjusted medium corresponding to that of the treated sample. A similar protocol was followed to determine optimal ionicity using media adjusted to $\mathrm{NaCl}$ concentrations ranging from 0.3 $\mathrm{M}$ to $0.6 \mathrm{M}$. Controls as described above for the standard assay were included. For all experimental assays, the normal growth of $P$. citreus and the antibacterial effect on the growth of $P$. citreus was monitored by measuring OD at specific time intervals up to 12 hours. Optimal incubation temperature was determined by performing the assay at $30^{\circ} \mathrm{C}$ and $\mathrm{RT}\left(\sim 25^{\circ} \mathrm{C}\right)$.

To determine the optimal concentration of $P$. citreus to develop a highly sensitive assay capable of detecting relatively low levels of antibacterial activity, assays were 
designed using three different concentrations of target organism. A bacterial suspension, standardized to 0.5 at $O D_{580 \mathrm{~nm}}$, which corresponded to a bacterial count of approximately $10^{6} \mathrm{CFU} / \mathrm{ml}$, was diluted $1: 10\left(1 \times 10^{5} \mathrm{CFU} / \mathrm{ml}\right), 1: 20\left(5 \times 10^{4} \mathrm{CFU} / \mathrm{ml}\right)$ and 1:40 $\left(2.5 \times 10^{4} \mathrm{CFU} / \mathrm{ml}\right)$ with $1 \times \mathrm{SCM}$. Five hundred $\mu \mathrm{l}$ of each concentration of bacterial suspension was plated onto SWA plates and incubated for 18 hours at $30^{\circ} \mathrm{C}$. The colony forming units were calculated from these plates to confirm each bacterial suspension concentration.

The microdilution growth assay was also used as a quantitative assay to measure the level of antibacterial activity in samples. Quantitative assays were set up by adding $50 \mu$ of the test sample to $50 \mu$ of diluent (1x SCM) in the second well and continuing to serially dilute the sample up to 1:32 dilution using 2-fold serial dilution in SCM. The first well contained $50 \mu \mathrm{l}$ of undiluted sample. Each assay was set up in triplicate. The microtiter plates were mixed on a microplate shaker for $5 \mathrm{~min}$, and absorbance read at $\mathrm{OD}_{570 \mathrm{~nm}}$. The plate was further incubated at $30^{\circ} \mathrm{C}$ for 12 hours and absorbance read again at $O D_{570 n m}$. The level of activity was calculated from $O D$ reading and expressed as a titer and measured as percent inhibition using the formula:

Percent Inhibition $=\underline{\mathrm{OD}}_{570 \mathrm{~nm}}$ of $P$. citreus control- $\mathrm{OD}_{570 \mathrm{~nm}}$ of sample $\times 100$ $\mathrm{OD}_{570 \mathrm{~nm}}$ of Planococcus citreus control

Antibacterial titer was defined as the inverse of the highest dilution of the test sample that showed inhibition ( $>5 \%$ ) of growth of the target organism (Herbert et al. 1977). 


\section{Fractionation of Cell Lysates}

Screening of cell lysate supernatant showed two distinctly different activities, a lysozyme-like activity and non-lysozyme-like antibacterial activity. In order to separate the molecules responsible for these two activities, ion exchange and affinity chromatography were undertaken. Earlier studies showed that recovery of antibacterial activity from cation exchange chromatography was not optimal (low recovery of activity). Therefore, initial fractionation of cell lysates was accomplished by anion exchange chromatography employing a weak (DE-52 cellulose, Whatman), a medium strength (DE Sepharose, Pharmacia), and a strong (Q-sepharose, Pharmacia) ion exchanger. The use of different ion exchangers was carried out to determine which protocol would achieve optimal separation and yield significant recovery of antibacterial activity. Following chromatographic separation active fractions were pooled and further fractionated by affinity chromatography on a heparin affinity column. All chromatography was carried out at room temperature $\left(25^{\circ} \mathrm{C}\right)$ and columns were run using a peristaltic pump at a constant flow rate. Fractions were collected and $\mathrm{OD}_{280 / 260 \mathrm{~nm}}$ read manually on a spectrophotometer (Ultraspec 3000, Pharmacia). Fractions were assayed for antibacterial activity using the standard microdilution growth assay while lysozyme activity was screened using the lysoplate assay. Active fractions were pooled, concentrated by freeze-drying, and reconstituted in smaller volumes of $d \mathrm{dH}_{2} \mathrm{O}$. The concentrated pools were stored at $-20^{\circ} \mathrm{C}$ until needed for further processing. 


\section{Anion exchange chromatography using DE 52 Cellulose}

Preswollen diethyl aminoethyl cellulose (DE 52, Whatman), a microgranular cellulose matrix, was rehydrated in $0.02 \mathrm{M}$ Tris- $\mathrm{HCl}, 0.05 \mathrm{M} \mathrm{NaCl}, \mathrm{pH}$ 7.5. The $\mathrm{pH}$ of the suspension was adjusted to 7.5 with $10 \mathrm{~N} \mathrm{NaOH}$. The buffer was decanted and discarded, and the gel washed several times with equilibration buffer $(0.02 \mathrm{M}$ Tris- $\mathrm{HCl}$, $0.05 \mathrm{M} \mathrm{NaCl}, \mathrm{pH} 7.5$ ) until the $\mathrm{pH}$ and ionicity of the gel mix was the same as the equilibration buffer. A column measuring $1.0 \mathrm{~cm}$ diameter $\times 4.5 \mathrm{~cm}$ in length was poured (bed volume of $3.6 \mathrm{ml}$ ), and equilibrated with $20 \mathrm{ml}$ equilibration buffer. The flow rate was adjusted to $0.5 \mathrm{ml} / \mathrm{min}$ and $0.75 \mathrm{ml}$ fractions were collected. Sample material was mixed with equilibration buffer in a ratio of $3: 1$, before being applied to the column. The column was washed until all unbound protein had been collected and the $\mathrm{OD}_{280 \mathrm{~nm}}$ of the eluant was the same as the equilibration buffer. Proteins bound to the column were eluted with a linear $\mathrm{NaCl}$ gradient formed in a gradient mixer (Hoefer SG-100, Pharmacia) using an equal volume $(20 \mathrm{ml})$ of elution buffer $(0.02 \mathrm{M}$ Tris- $\mathrm{HCl}$, $0.5 \mathrm{M} \mathrm{NaCl}, \mathrm{pH} 7.5$ ) and equilibration buffer. After the gradient, an additional $10 \mathrm{ml}$ of high salt buffer (0.02 M Tris- $\mathrm{HCl}, 1 \mathrm{M} \mathrm{NaCl}, \mathrm{pH} 7.5)$ was applied to the column to elute all tightly bound protein. Fractions were assayed for antibacterial activity and lysozyme as described above. Those exhibiting antibacterial activity were pooled and concentrated by lyophilization and stored at $-20^{\circ} \mathrm{C}$ until needed. 
Anion exchange chromatography using Q Sepharose or DE Sepharose

Q Sepharose and DE Sepharose are beaded agarose matrices (Pharmacia, NJ). Material was washed several times with equilibration buffer $(0.02 \mathrm{M}$ Tris- $\mathrm{HCl}, 0.05 \mathrm{M}$ $\mathrm{NaCl}, \mathrm{pH} 7.5$ ) to remove the ethanol preservative and a column measuring $1.0 \mathrm{~cm}$ diameter $\times 4.5 \mathrm{~cm}$ in length (bed volume of $3.8 \mathrm{ml}$ ) was prepared according to the procedure described above for DE cellulose and run under similar conditions except the flow rate was adjusted to $0.5 \mathrm{ml} / \mathrm{min}$ and $1 \mathrm{ml}$ fractions were collected. Active fractions were pooled, dialyzed, concentrated by freeze-drying, and stored at $-20^{\circ} \mathrm{C}$ until needed.

Heparin-sepharose affinity chromatography

Heparin is a glycosaminoglycan which serves as an effective affinity binding and ion exchange ligand for a wide range of bio-molecules and has been shown to bind enzymes/proteins that act on nucleic acids. Heparin-Sepharose, a highly cross-linked agarose matrix (Pharmacia, $N J$ ), was washed several times with equilibration buffer (0.1 $\mathrm{M}$ Tris, $0.01 \mathrm{M}$ citric acid, $0.075 \mathrm{M} \mathrm{NaCl}, \mathrm{pH} 7.5$ ) to remove the ethanol and a column was poured measuring $0.7 \mathrm{~cm}$ diameter $\times 2.5 \mathrm{~cm}$ in length (bed volume of $1 \mathrm{ml}$ ). The column was washed with $10 \mathrm{ml}$ of equilibration buffer and when the ionicity of the column eluant was similar to that of the equilibration buffer the sample was applied to the column. The flow rate was adjusted to $0.75 \mathrm{ml} / \mathrm{min}$ and $0.5 \mathrm{ml}$ fractions were collected. Following the application of the sample, the column was washed with equilibration buffer (approximately $10 \mathrm{ml}$ ) until the $\mathrm{OD}_{280 \mathrm{~nm}}$ of fractions were the same as the equilibration 
buffer. Proteins bound to the column were then eluted with a linear $\mathrm{NaCl}$ gradient using equal volumes $(20 \mathrm{ml}$ ) of elution buffer ( $0.1 \mathrm{M}$ Tris, $0.01 \mathrm{M}$ citric acid, $2 \mathrm{M} \mathrm{NaCl}, \mathrm{pH} 7.5$ ) and equilibration buffer. After the gradient, an additional $15 \mathrm{ml}$ of high salt buffer $(0.1 \mathrm{M}$ Tris, $0.01 \mathrm{M}$ citric acid, $2 \mathrm{M} \mathrm{NaCl}, \mathrm{pH} 7.5$ ) was applied to the column to elute all tightly bound protein. Fractions were assayed for antibacterial activity by the standard microdilution growth assay. Those exhibiting antibacterial activity were pooled, dialyzed, concentrated by freeze-drying, and stored at $-20^{\circ} \mathrm{C}$ until needed.

\section{SDS-PAGE Analysis of Chromatography Fractions}

Sodium dodecyl sulfate polyacrylamide gel electrophoresis (SDS-PAGE) is a rapid and reproducible way of analyzing proteins under reducing and non-reducing conditions, on the basis of their molecular size and mobility through gel matrix (Laemmli 1970). It is also a more accurate and dependable method than gel filtration for determining the molecular size of proteins/peptides of interest. Column fractions were analyzed by SDS-PAGE under reducing and non-reducing conditions to determine protein composition. Gels were either purchased commercially (gradient 10-20\% TrisTricine Criterion gels) (Bio-Rad, CA), or poured in the laboratory (single percentage $7.5 \%$ and $10 \%$ ). Samples were mixed in a $4: 1$ ratio with $5 x$ sample buffer (with or without $5 \%$ mercaptoethanol), and $30 \mu$ l of each sample loaded into individual wells. Protein standards used as molecular weight markers consisted of a commercial mixture of proteins (Bio-Rad, CA) that included myosin (200 kDa), $\beta$-galactosidase 
(116.3 kDA), phosphorylase B (97.4 kDa), BSA (66.3 kDa), ovalbumin (45 kDa), carbonic anhydrase (31 kDa), soybean trypsin inhibitor (21.5 kDa), lysozyme (14.4 kDa) and aprotinin (6.5 kDa). Criterion gels (Bio-Rad, CA) were electrophoresed at room temperature at 200V (0.06 Amps) using chilled 1X Running buffer containing $0.1 \%$ SDS. Electrophoresis was stopped when the dye front migrated to the bottom of the gel. The gels were stained with Coomassie R-250 for 10 min with gentle agitation and destained for 24 hours in a solution containing $37.5 \%$ methanol, $10 \%$ acetic acid and 2.5\% glycerol. Gels were then dried in a Model 450 gel dryer (Bio-Rad, CA), following manufacturer's instructions.

\section{Western Blot}

To identify whether proteins contained in active samples were histones/histone fragments, samples were analyzed in Western blots using heterologous antisera raised against a variety of human histone proteins. Western blots were set up as follows: following SDS-PAGE of samples, gels were equilibrated in transfer buffer for 15-20 min. Nitrocellulose membrane (Bio-Rad, CA) was first equilibrated with $100 \%$ methanol for 5 min, then added to the container with electrophoresed gel to equilibrate in transfer buffer for an additional $15 \mathrm{~min}$. A "sandwich" of the gel and nitrocellulose membrane (in close contact and with no trapped air bubbles) between filter paper and sponge pads was carefully put together. Proteins from the gel were transferred to the membrane through electro-blotting by electrophoresing the sandwich for $1 \mathrm{hr}$ at 100 volts. 
Following transfer, the membrane was separated from the gel and immersed in blocking solution and incubated with gentle shaking for $90 \mathrm{~min}$ at room temperature followed by overnight incubation at $10^{\circ} \mathrm{C}$. The blocking step was to ensure that all "sticky" sites on the membrane were blocked with milk protein contained in the blocking solution. After overnight incubation the blocking solution was decanted and the membrane washed with diluent buffer with gentle agitation, for 5 - 10 min at RT. The wash buffer was discarded and the membrane washed once more with wash buffer. Primary antibody reagent $(10 \mathrm{ml})$ was added to the membrane and incubated at room temperature for $3 \mathrm{hr}$ after which the primary antibody was removed and unbound antibody washed away from the membrane by adding more wash diluent buffer and incubating at RT for additional $20 \mathrm{~min}$. This wash step was repeated once more. The wash buffer was discarded and the secondary antibody conjugate reagent $(10 \mathrm{ml})$ was added and incubated at room temperature for $1 \mathrm{hr}$. After incubation, the secondary antibody reagent was decanted, and the membrane washed in buffer to wash away all unbound conjugate from the blot. The wash step was achieved by gently agitating the membrane for another $10 \mathrm{~min}$ at RT. The membrane was washed twice more. To develop the blot for visualization of reactive protein bands the membrane was immersed in $10 \mathrm{ml}$ of HRP color development solution (Bio-Rad, CA) until color development was complete (approximately 2 - $5 \mathrm{~min}$ ). Color development was stopped by immersing the membrane in distilled water for $5 \mathrm{~min}$. Forceps were used to handle the membrane, placing it between two filter pads until dry and then wrapped in foil paper for storage at $-20^{\circ} \mathrm{C}$. 


\section{Correlation of Antibacterial Activity with Specific Protein Bands}

To correlate antimicrobial activity detected in samples with a specific protein, active fractions were subjected to polyacrylamide gel electrophoresis under acid conditions, and the gel containing separated proteins/peptides was overlaid on an agarose seeded with Planococcus citreus (the underlay). The overlay permits protein bands to diffuse into the agarose and inhibit the growth of the bacterial lawn.

Acid-urea (AU) electrophoresis was performed using 12.5\% acid-urea gels which were pre-run for $1 \mathrm{hr}$ with reversed polarity at $30 \mathrm{~mA} / 120 \mathrm{~V}$ using $5 \%$ acetic acid in both upper and lower buffer chambers. The running buffer was discarded and the gel assembly rinsed with $d \mathrm{dH}_{2} \mathrm{O}$ and reassembled with fresh buffer. Test samples were diluted in $5 \%$ acetic acid, mixed with $3 x$ sample buffer and immediately loaded into wells of two gels in identical order and run as before with fresh $5 \%$ acetic acid for 50 min at $80-100 \mathrm{~V}$ at reverse polarity. After the gels were removed from the apparatus, one gel was stained with Laemmli coomassie stain while the other was rinsed three times with rinse buffer (changing rinse buffer every $5 \mathrm{~min}$ ).

The washed gel was placed on an agarose underlay and the plates incubated at $30^{\circ} \mathrm{C}$ for $3 \mathrm{hr}$ to permit diffusion of the protein/peptide bands into the underlay containing the target organism. The underlay was prepared by adding $100 \mu \mathrm{l}$ of a standardized suspension of Planococcus citreus (approximately $10^{6}$ organisms $/ \mathrm{ml}$ ) to $10 \mathrm{ml}$ of molten $\left(44^{\circ} \mathrm{C}\right) 1 \%$ agarose, and allowing the mixture to solidify in a petri dish (100 x $15 \mathrm{~mm}$ square with $13 \mathrm{~mm}$ grid) at room temperature. Using the sterile tip of a 
$3 \mathrm{~mm}$ diameter template cutter, two wells were punched into the agar along the periphery of the plate. $5 \mu$ l each of positive control, HNP1 $(25 \mu \mathrm{g} / \mathrm{ml})$ and negative control (3.2\% saline solution) were then added to each respective well. Following incubation the gel was removed and stained (to determine efficiency of transfer) and the surface of each plate was overlaid with $10 \mathrm{ml}$ of molten overlay nutrient medium necessary for bacterial growth (artificial sea water complete broth in $1 \%$ agar). Once the overlay had solidified, the plates were inverted and incubated at $30^{\circ} \mathrm{C}$ for $24 \mathrm{hr}$. The plates were examined for clear zones of inhibition of bacterial growth. The bacterial lawn appeared as a uniform turbid background. The plate was stained with the modified coomassie stain and photographed using a digital camera (Sony).

\section{Amino Acid Sequence Analysis of Lysate Proteins/Peptides}

Amino acid sequence data for specific proteins/peptides identified in lysate fractions was obtained either by Edman degradation (yielding $\mathrm{N}$-terminal sequence) or by LC-MS/MS analysis of trypsin digests. Samples for analysis were lysate fractions in which antibacterial activity had been detected either by the agar diffusion assay or the standard microdilution growth assay with activity further correlated to specific protein band(s) by AU gel overlay assays.

Samples for N-terminal sequence analysis by Edman degradation were prepared as follows. Briefly, samples were subjected to SDS-PAGE, gels were equilibrated in transfer buffer containing $10 \%$ methanol for five minutes, and placed in a sandwich 
containing the PVDF membrane in direct contact with the gel, and insulated with filter paper and fiber pads to ensure proper transfer. The sandwich was electrophoresed at 100V for $1 \mathrm{hr}$ (Criterion Gel System, Bio-Rad) and the membrane was removed from the sandwich and stained for 1 min in $0.02 \%$ Coomassie R-250 solution containing $40 \%$ methanol. It was then placed in destain solution of $40 \%$ methanol for up to $1 \mathrm{~min}$ and washed in distilled water for 3-5 min with at least three changes of water. Forceps were used to handle the membrane, placing it between two filter pads until dry and then wrapped in foil paper before mailing to the protein core facility (ICBR, University of Florida) for $\mathrm{N}$-terminal sequence analysis. Protein bands that corresponded to those that (1) reacted in a Western blot with antisera to specific histones and/or (2) demonstrated antibacterial activity in acid urea overlay assays were chosen for sequencing.

Samples for trypsin digestion and LC-MS/MS analysis were prepared by subjecting them to SDS-PAGE analysis then gels were stained for 1 hour with Coomassie stain (New England Biolabs, MA), followed by destaining with water for $30 \mathrm{~min}$. The bands selected for analysis were excised with a scalpel blade and placed in an eppendorf tube and stored at $-20^{\circ} \mathrm{C}$ until shipped in dry ice to the protein core facility (ICBR, University of Florida) for tryptic digestion and LC-MS/MS analysis.

The trypsin digested samples were injected onto a capillary trap (LC Packings, PepMap) and desalted for 5 min with a flow rate $3 \mu \mathrm{l} / \mathrm{min}$ of $0.1 \% \mathrm{v} / \mathrm{v}$ acetic acid. The samples were loaded onto an LC Packing ${ }^{\circledR}$ C18 Pep Map nanoflow HPLC column. The elution gradient of the HPLC column started at $3 \%$ solvent $A, 97 \%$ solvent $B$ and 
finished at $60 \%$ solvent $A, 40 \%$ solvent $B$ for 30 min for protein identification. Solvent $A$ consisted of $0.1 \%$ v/v acetic acid, $3 \% \mathrm{v} / \mathrm{v} \mathrm{ACN}$, and $96.9 \% \mathrm{v} / \mathrm{v} \mathrm{H} 2 \mathrm{O}$. Solvent B consisted of $0.1 \% \mathrm{v} / \mathrm{v}$ acetic acid, $96.9 \% \mathrm{v} / \mathrm{v} \mathrm{ACN}$, and $3 \% \mathrm{v} / \mathrm{v}$ H2O.LC-MS/MS analysis was carried out on a LTQ Orbitrap XL mass spectrometer (Fisher Scientific, GA). The ion spray voltage was set to 2200 V. Full MS scans were acquired with a resolution of 60,000 in the orbitrap from $\mathrm{m} / \mathrm{z}$ 300-2000. The five most intense ions were fragmented by collision induced dissociation (CID). Dynamic exclusion was set to 60 seconds. Protein search algorithm

Data from all MS/MS samples were analyzed using Mascot (Matrix Science, London, UK; version 2.2.2). Mascot was set up to search both NCBI and NCBI_chondichthes databases assuming trypsin digestion. Mascot was searched with a fragment ion mass tolerance of $10 \mathrm{ppm}$ and a parent ion tolerance of $10 \mathrm{ppm}$. lodoacetamide derivative of Cys, deamidation of Asn and GIn, oxidation of Met, are specified in Mascot as variable modifications. Scaffold (version Scaffold-03-00-04, Proteome Software Inc., Portland, OR) was used to validate MS/MS based peptide and protein identifications. Peptide identifications are accepted if they could be established at greater than $95.0 \%$ probability as specified by the Peptide Prophet algorithm. Protein identifications are accepted if they can be established at greater than $99.0 \%$ probability and contain at least two identified unique peptides. Protein probabilities were assigned by the Protein Prophet algorithm. 


\section{RESULTS}

\section{Composition of Leukocyte Fraction of Shark Peripheral Blood}

\section{Structural morphology of cell types}

Since the aim of the study is to identify proteins or peptides associated with antibacterial activity of leukocytes, it was essential to confirm that lysates made from leukocytes were made up of all leukocyte types. Figure 1a through 1e show different cell types found in nurse shark peripheral blood leukocytes. Two major granulocytic cells are present. One is eosinophil-like, a granulocyte with deeply staining eosinophilic intracytoplasmic granules with a lobed nucleus (Figure 1a). These cells are similar in staining properties to mammalian eosinophils. The second type of granulocytic cell is the neutrophil-like granulocyte, characterized by an eccentric, usually bi-lobed, nucleus surrounded by cytoplasm containing granules (Figure 1b), distinctly different from those of the eosinophilic granulocyte. Four types of mononuclear cells are present. The monocyte-macrophage cells are mononuclear and lack distinct granules. The nucleus is large and usually no more than half of the cell volume (Figure 1c). The second mononuclear cell is the lymphocyte-like cell (Figure 1d), which is similar to a mammalian lymphocyte with a spheroidal nucleus occupying much of the cell volume, and surrounded by a narrow rim of cytoplasm. The third cell type is the thrombocyte, which usually appears discoidal with a single, large, centrally placed, oval nucleus (Figure 1e). However, depending on how the blood is processed, thrombocytes may assume several distinct shapes (e.g., spiked, spindle or fragmented). Another cell type occasionally 
found in peripheral blood is the undifferentiated blast cell (not shown). This cell type exhibits an undistinguished cytoplasm with a central nucleus.

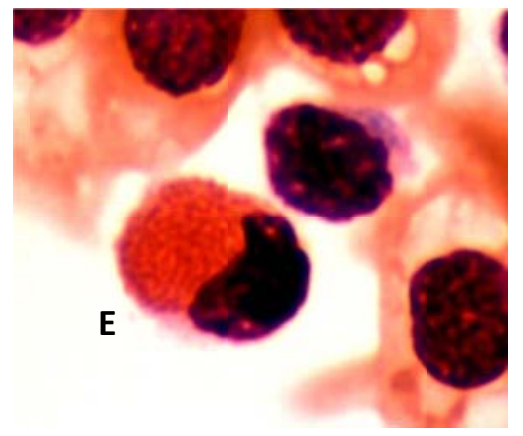

(a)

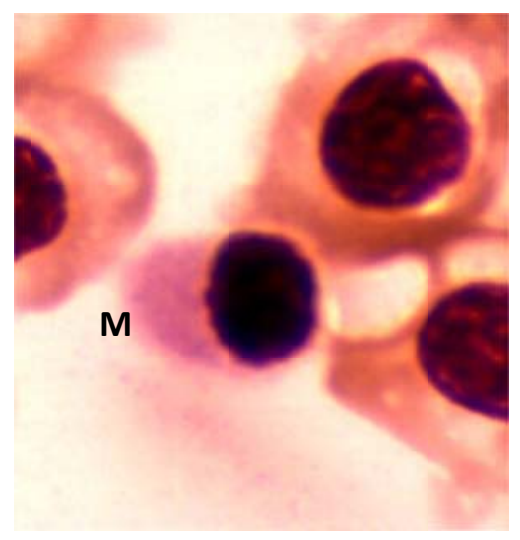

(c)

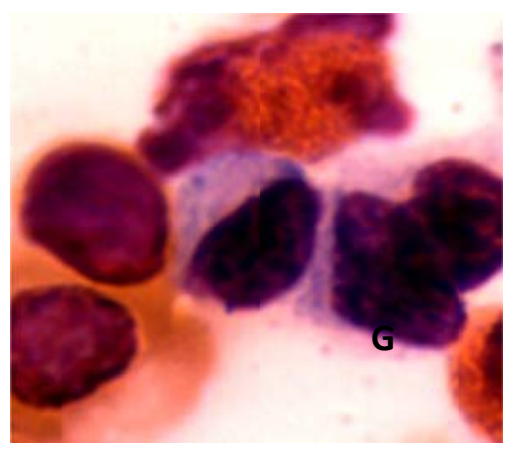

(b)

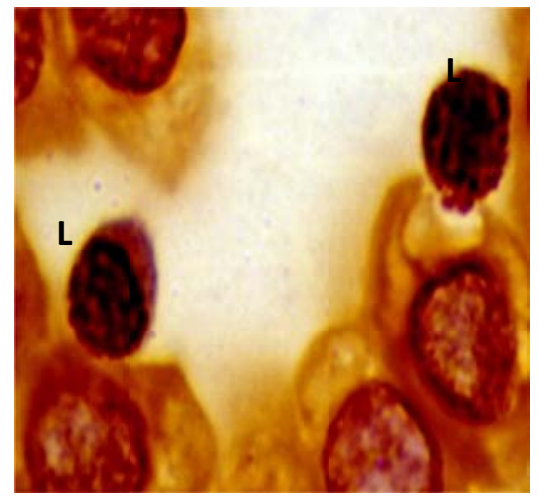

(d)

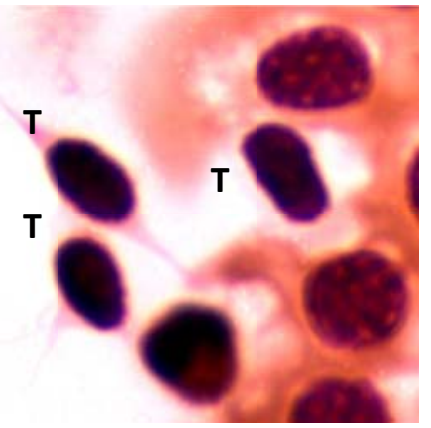

Figure 1 Cytospins of nurse shark peripheral blood cells. Cytospins made using heparinized nurse shark peripheral blood on poly-L-Lysine coated slides and stained with leukostat. (a) eosinophil-like , E. (b) neutrophilic granulocyte, G. (c) monocyte-macrophage, M. (d) lymphocyte-like, L. (e) thrombocytes, T. 


\section{Differential count of cell types}

Differential leukocyte counts (carried out in duplicate) of peripheral whole blood, from one individual, yielded relative numbers of the cell types. These are shown in Table 1, expressed as percentage, with 200 leukocytes counted per slide (average of three slides). A normal differential leukocyte count of human peripheral blood, expressed as percentage, is provided for comparison (Altman et al. 1961).

Table 1 Relative Numbers of Different Leukocytes in Nurse Shark (present study) and Human Peripheral Blood

\begin{tabular}{|c|c|c|c|}
\hline \multicolumn{2}{|c|}{ Nurse Shark Peripheral Blood } & \multicolumn{2}{|l|}{ Human Peripheral Blood } \\
\hline Cell Type & $\%$ & Cell Type & $\%$ \\
\hline Neutrophilic granulocyte & 32.5 & Neutrophilic granulocyte & 59 \\
\hline Eosinophil-like & 11.5 & Eosinophil & 2.7 \\
\hline Monocyte-macrophage & 2.5 & Monocyte-macrophage & 4 \\
\hline Lymphocyte-like & 40 & Lymphocyte & 34 \\
\hline Basophil & 0 & Basophil & 0.5 \\
\hline Thrombocyte & 13.5 & Thrombocyte & $\mathrm{n} / \mathrm{a}$ \\
\hline
\end{tabular}

\section{Detection and Quantitation of Antibacterial Activity of Leukocyte Lysates}

Lysates were prepared as stated in the materials and methods. Protein concentration of lysate preparations ranged from $2-8 \mathrm{mg} / \mathrm{ml}$, depending on the number of leukocytes harvested and the procedure used to disrupt cells. Initial screening of crude lysates for lysozyme and antibacterial activity was performed using the lysoplate 
and agar diffusion methods, respectively (Osserman et al. 1966; Lehrer et al. 1991;

Manchenko 1994). Antibacterial activity against Planococcus citreus was detected in all lysates tested, except for lysate sample \#3 at $25^{\circ} \mathrm{C}$ (Table 2).

Table 2 Quantitation of Antibacterial Activity of Different Preparations of Leukocyte Lysates

\begin{tabular}{|c|c|c|c|}
\hline & \multirow[t]{2}{*}{ Lysate sample } & \multicolumn{2}{|c|}{ AU } \\
\hline & & At $30^{\circ} \mathrm{C}$ & At $25^{\circ} \mathrm{C}$ \\
\hline \#1 & Leukocyte lysate sample & 35 & 25 \\
\hline \#2 & Leukocyte lysate sample & 50 & 40 \\
\hline \#3 & Leukocyte lysate sample & 5 & 0 \\
\hline \#4 & Leukocyte lysate sample & 40 & 15 \\
\hline \#5 & Leukocyte lysate sample & 45 & 30 \\
\hline \#6 & Leukocyte lysate sample & 80 & 60 \\
\hline
\end{tabular}

NOTE: Activity Units (AU) represents the average of duplicate readings at each temperature

The modified radial diffusion assay supplemented with sea water complete medium (SCM) was semi-quantitative and antibacterial activity was estimated by measurement of the diameter of the zones of inhibition as seen in Figure 2. The level of antibacterial activity varied from preparation to preparation as expected, because lysates were prepared from different blood samples, collected at different times. Antibacterial assays carried out at $30^{\circ} \mathrm{C}$ showed larger and more pronounced zones of inhibition than 
assay plates incubated at $25^{\circ} \mathrm{C}$ (Figure $2 \mathrm{a}$ and b), using similar samples. Antibacterial activity was expressed in arbitrary activity units $(A U)$ calculated from the diameter of the zone of inhibition (for details see Methods) (Table 2) according to the formula: Arbitrary activity units $=($ Diameter of zone of inhibition $(\mathrm{mm})-$ Diameter of well $(\mathrm{mm})) \times 10$
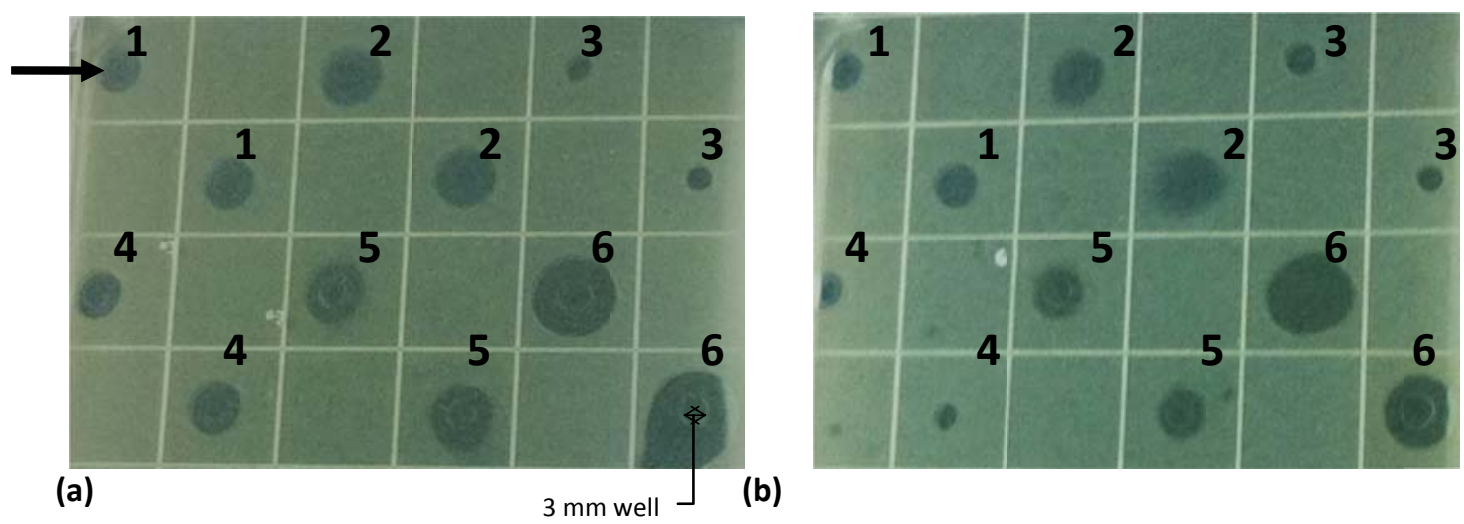

Figure 2 Representative radial diffusion assay plates. Antibacterial activity is seen as a clear area (arrow) around wells (wells are $3 \mathrm{~mm}$ in diameter). Duplicate samples $(10 \mu \mathrm{l})$ of six different lysate preparations (1-6 in figure) were individually added to wells. Duplicate plates were incubated (a) at $30^{\circ} \mathrm{C}$ and (b) at $25^{\circ} \mathrm{C}$. Diameter of the zones was measured after $24 \mathrm{~h}$ incubation and antibacterial activity expressed in activity units calculated according to the formula in materials and methods (Table 2).

When lysates were prepared from different bleeds, and antibacterial activity was measured at $25^{\circ} \mathrm{C}$ and $30^{\circ} \mathrm{C}$, it was seen that activity, as shown by zones of inhibition measured (Figure 2a, arrow), was consistently higher when plates were incubated at $30^{\circ} \mathrm{C}$ as opposed to $25^{\circ} \mathrm{C}$.

When assaying for lysozyme-like activity using the lysoplate assay, retention of activity was inconsistent and was affected by the method used to prepare the extracts, i.e., mechanical shearing, homogenization versus sonication. When the method of preparation was mechanical shearing or glass homogenization, the lysozyme-like activity 
was detected. However, when the method of preparation was sonication, the lysozyme-like activity could not be detected by the lysoplate assay.

Development of a microdilution growth assay

The radial diffusion assay was effective as an initial screening method, however, a more sensitive and accurate assay, such as a microdilution growth assay (not currently available for sharks) was necessary.

In order to develop this assay, optimal conditions $(\mathrm{pH}$, salinity, incubation temperature, etc.) for growth of the target organism, $P$. citreus, and for antibacterial activity (growth inhibition) was determined.

(1) Growth curve of $P$. citreus in SCM

Growth of Planococcus citreus in SCM was monitored by measuring OD at 570 and $630 \mathrm{~nm}$ in micro-well plates over a period of $24 \mathrm{~h}$ at $30^{\circ} \mathrm{C}$ (Figure 3). The culture reached mid-log phase in 10 hours. No significant difference was noted between OD readings taken at 570 or $630 \mathrm{~nm}$, and subsequent experiments measuring bacterial growth were read at $570 \mathrm{~nm}$. Ten $\mathrm{h}$ cultures (growing exponentially) were used as target cell inoculum for all future microdilution growth assays.

(2) Effect of $\mathrm{pH}$ and salinity on $P$. citreus growth Microdilution growth assays were set up in SCM medium adjusted to varying $\mathrm{pH}$ $(4.0,5.5,6.5,7.5$ and 8.5$)$ and salinity $(0.3 \mathrm{M}, 0.4 \mathrm{M}, 0.5 \mathrm{M}, 0.6 \mathrm{M} \mathrm{NaCl})$. Since previous radial diffusion assays had shown enhanced antibacterial activity at $30^{\circ} \mathrm{C}$, microdilution growth assays were incubated at $30^{\circ} \mathrm{C}$. The data shown in Table 3 are represented by $\mathrm{OD}_{570 \mathrm{~nm}}$. Growth at $\mathrm{pH} 4.0,5.5$ and 6.5 was minimal. Growth did 
occur at $\mathrm{pH} 7.5$ and 8.5. For the standard assay, a $\mathrm{pH}$ of 7.5 was chosen as it is closer to physiological pH for shark leukocytes. Planococcus citreus grew at identical rates in $\mathrm{SCM}$ adjusted to a final $\mathrm{NaCl}$ concentration of $0.3 \mathrm{M}, 0.4 \mathrm{M}, 0.5$ and $0.6 \mathrm{M} \mathrm{NaCl}$.

Since the concentration of $\mathrm{NaCl}$ in SCM is normally $0.5 \mathrm{M}$, all assays were performed using SCM without adjusting salt concentration.

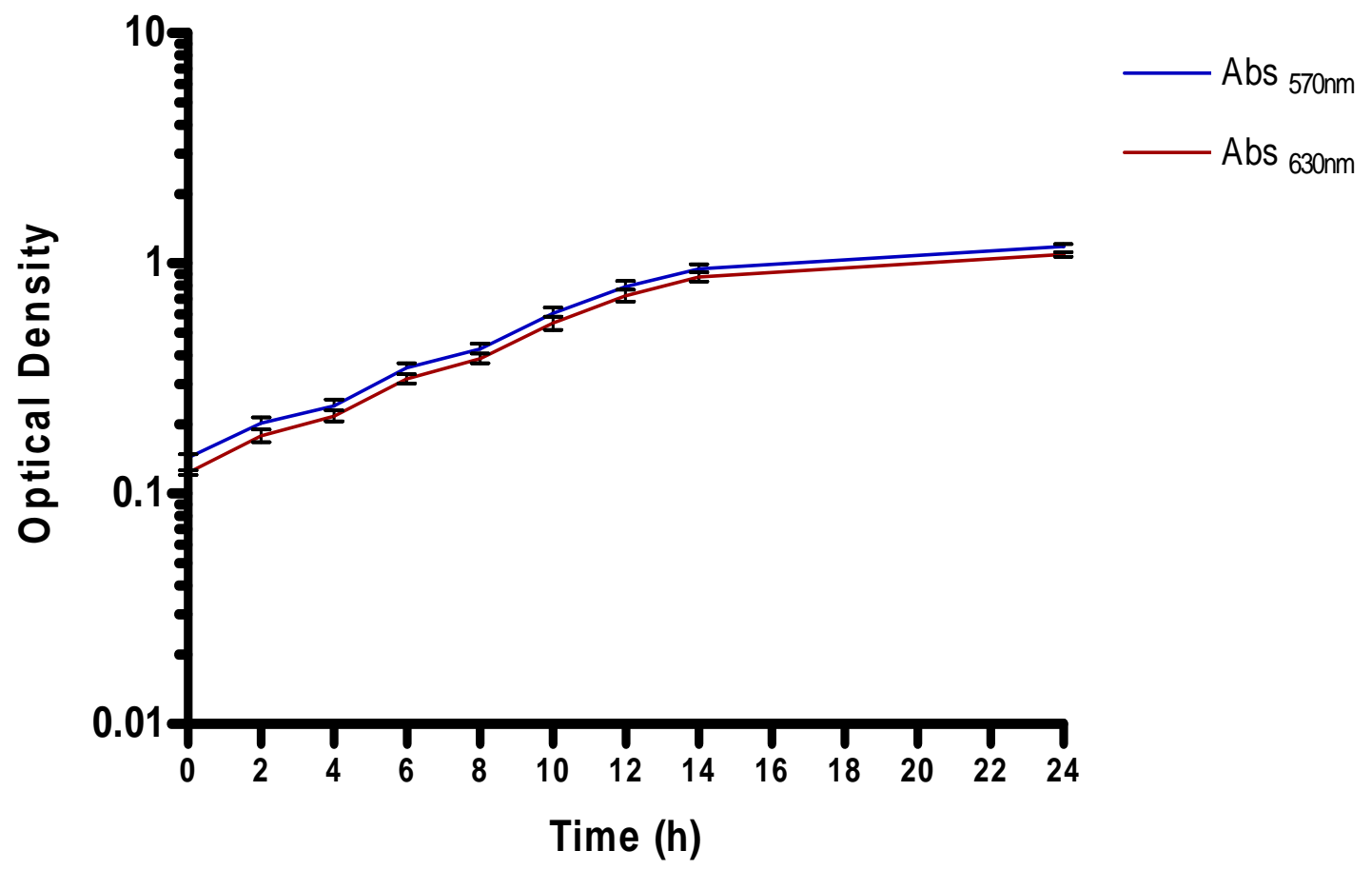

Figure 3 Growth of Planococcus citreus in Sea water Complete Medium. A $10 \mathrm{~h}$ culture (50 $\mathrm{\mu l}$ ) of $P$. citreus in sea water complete medium (SCM) was inoculated into $50 \mu$ fresh 2x SCM (salt concentration was unchanged (1x) in double strength media). The culture was incubated at $30^{\circ} \mathrm{C}$ and $O D$ read at $2 \mathrm{~h}$ intervals in a Dynex ELISA reader at wavelength 570 and $630 \mathrm{~nm}$. Each point represents an average OD reading of samples from triplicate cultures. Error bars fall within plot points and are not visible. 
Table 3 Effect of pH and Salinity on Growth of Planococcus citreus

\begin{tabular}{|l|l|l|}
\hline \multirow{2}{*}{$\begin{array}{l}\mathbf{p H} \text { of } \\
\text { media }\end{array}$} & \multicolumn{2}{|c|}{ OD } \\
\cline { 2 - 3 } & $\mathbf{O h}$ & $\mathbf{1 2} \mathbf{h}$ \\
\hline $\mathbf{4 . 0}$ & 0.004 & 0.013 \\
$\mathbf{5 . 5}$ & 0.004 & 0.021 \\
$\mathbf{6 . 5}$ & 0.003 & 0.055 \\
$\mathbf{7 . 5}$ & 0.007 & 0.326 \\
$\mathbf{8 . 5}$ & 0.004 & 0.280 \\
\hline
\end{tabular}

\begin{tabular}{|l|l|l|}
\hline \multirow{2}{*}{$\begin{array}{c}\text { NaCl concentration } \\
\text { of media }\end{array}$} & \multicolumn{2}{|c|}{ OD } \\
\cline { 2 - 3 } & $\mathbf{0 ~} \mathbf{h}$ & $\mathbf{1 2} \mathbf{~}$ \\
\hline $\mathbf{0 . 3 M}$ & 0.003 & 0.307 \\
$\mathbf{0 . 4 M}$ & 0.004 & 0.285 \\
\hline $\mathbf{0 . 5 M}$ & 0.009 & 0.321 \\
\hline $\mathbf{0 . 6 M}$ & 0.010 & 0.312 \\
\hline
\end{tabular}

(a)

(b)

NOTE: A $10 \mathrm{~h}$ culture (100 $\mu \mathrm{l})$ of $P$. citreus in SCM was inoculated into $75 \mu \mathrm{l}$ fresh $2 \times \mathrm{SCM}$, adjusted to (a) different $\mathrm{pH}$ and (b) different salinity. The culture was incubated at $30^{\circ} \mathrm{C}$ and $O \mathrm{OD}_{570 \mathrm{~nm}}$ read at $2 \mathrm{~h}$ intervals in a Dynex ELISA reader. Each point represents an average OD reading of samples from duplicate cultures.

(3) Determination of optimal temperature for $P$. citreus growth and antibacterial activity of lysate for microdilution growth assay

Optimal incubation temperature was determined by monitoring growth of $P$.

citreus with and without the lysate at $30^{\circ} \mathrm{C}$ and $25^{\circ} \mathrm{C}$ (Table 4). Thirty degree celsius was optimal for growth of the target organism and maximal for antibacterial activity of the lysate.

Table 4 Effect of Temperature on P. citreus Growth and Antibacterial Activity of Leukocyte Lysate

\begin{tabular}{|c|c|c|}
\hline \multirow{2}{*}{$\begin{array}{l}\text { Incubation } \\
\text { temperature }\end{array}$} & \multicolumn{2}{|c|}{ OD } \\
\hline & $\mathrm{Oh}$ & $12 \mathrm{~h}$ \\
\hline $25^{\circ} \mathrm{C}$ & 0.013 & 0.036 \\
\hline $30^{\circ} \mathrm{C}$ & 0.011 & 0.119 \\
\hline $25^{\circ} \mathrm{C}+$ lysate & 0.032 & 0.052 \\
\hline $30^{\circ} \mathrm{C}+$ lysate & 0.032 & 0.048 \\
\hline
\end{tabular}

NOTE: Planococcus citreus cultures were incubated with and without lysate and incubated at $25^{\circ} \mathrm{C}$ and $30^{\circ} \mathrm{C}$. Bacterial growth was measured by taking OD ${ }_{570 \mathrm{~nm}}$ readings at $2 \mathrm{~h}$ intervals in a Dynex ELISA. Each reading represents an average $O D$ reading from triplicate cultures. 
(4) Determination of optimal target cell density for microdilution growth assay

The optimal concentration of Planococcus citreus for the assay was determined by performing the assay using two different concentrations of bacteria; $1 \times 10^{5}$

$\mathrm{CFU} / \mathrm{ml}$ and $2.5 \times 10^{4} \mathrm{CFU} / \mathrm{ml}$. The effect of crude lysate, concentrated four-fold, on Planococcus citreus growth was followed over a $24 \mathrm{hr}$ period at $30^{\circ} \mathrm{C}$. At 10 hours no significant effect (antibacterial) on growth of $P$. citreus was noted at a cell density of $1 \times 10^{5} \mathrm{CFU} / \mathrm{ml}$ (Figure 4). Lack of activity may be caused by excessive cell density, masking any inhibitory effect. Antibacterial activity was measurable as inhibition of growth after 4 hours, at a cell density of $2.5 \times 10^{4} \mathrm{CFU} / \mathrm{ml}$. This was the density of target cells used for all future assays.

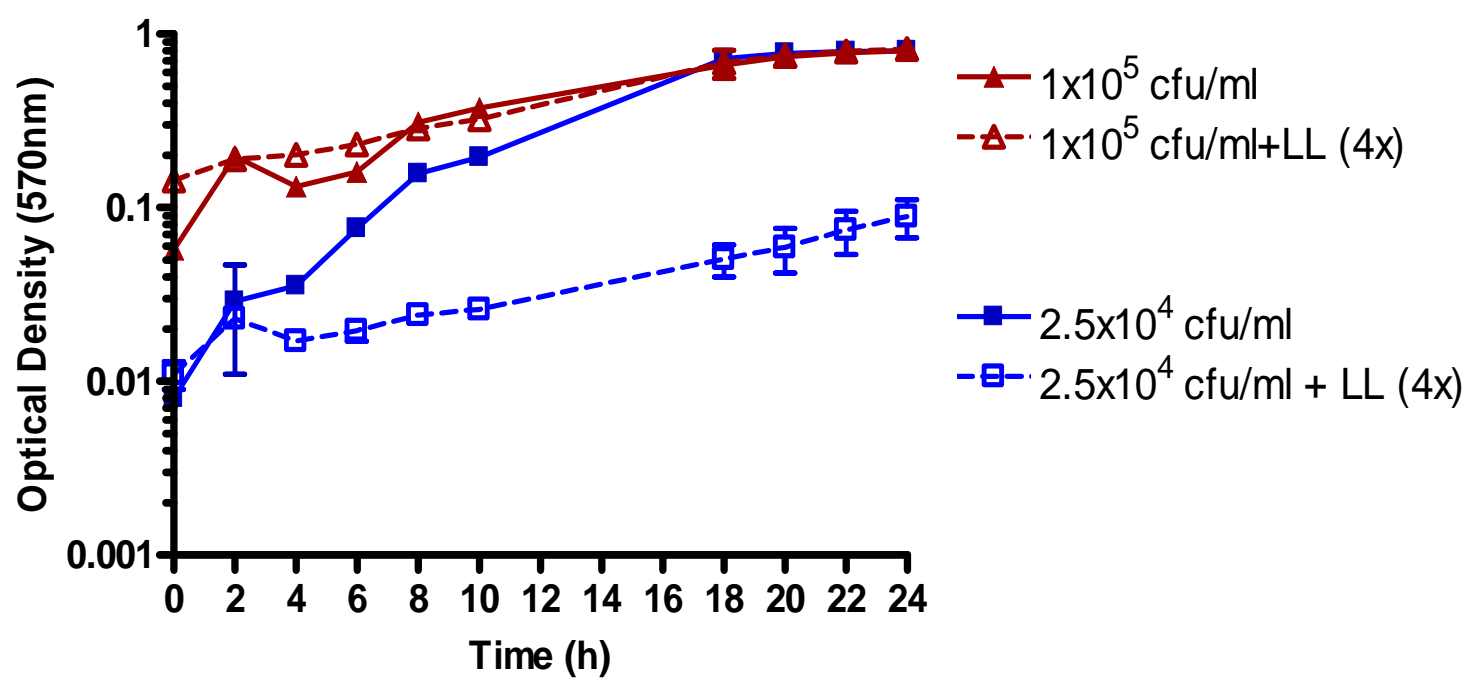

Figure 4 Antibacterial effect of leukocyte lysates on growth of Planococcus citreus at different target cell densities. A four-fold concentration of the crude extract was added to different densities of $P$. citreus ( $1 \times 10^{5} \mathrm{CFU} / \mathrm{ml}$ and $2.5 \times 10^{4} \mathrm{CFU} / \mathrm{ml}$ ) and bacterial growth at $30^{\circ} \mathrm{C}$ was compared to corresponding control culture consisting of $P$. citreus in the absence of lysate. Each reading represents an average $\mathrm{OD}_{570 \mathrm{~nm}}$ of samples from triplicate cultures (measured at $2 \mathrm{~h}$ intervals for $24 \mathrm{~h}$ ). 
(5) Sensitivity of microdilution growth assay

The minimum threshold level of antibacterial activity detectable (in crude lysate) by micro-titration was determined by measuring the antibacterial effect of different concentrations of lysate on growth of $P$. citreus. A crude lysate (1x), a two-fold diluted $(0.5 x)$ sample and a four-fold concentrated sample of the same lysate $(4 x)$ were compared for growth inhibition (Figure 5). There was no appreciable difference in bacterial growth when the culture with lysate, diluted two-fold $(0.5 x)$, was compared to the control culture. However, inhibition of bacterial growth was shown by the crude lysate (1x) after 10 hours, and by the $4 x$ concentrated lysate by 4 hours. Results indicate that the antibacterial activity of crude lysates can be measured by the assay after 10 hours of incubation. The end point for the standard assay was set for 12 hours (Figure 5b).

(6) Establishment of standardized microdilution growth assay

On the basis of the results above, the microdilution growth assay was standardized as follows. Each assay consisted of $50 \mu$ l of test sample, $75 \mu \mathrm{l}$ of $2 \mathrm{x}$ SCM and $100 \mu$ standardized $P$. citreus inoculum $\left(2.5 \times 10^{4} \mathrm{CFU} / \mathrm{ml}\right.$, final concentration). The SCM contained $0.5 \mathrm{M} \mathrm{NaCl}$ and $\mathrm{pH}$ was adjusted to 7.5. Assays were set up in triplicate and incubated at $30^{\circ} \mathrm{C}$ for up to 12 hours. Wells were read at OD $570 \mathrm{~nm}$. 


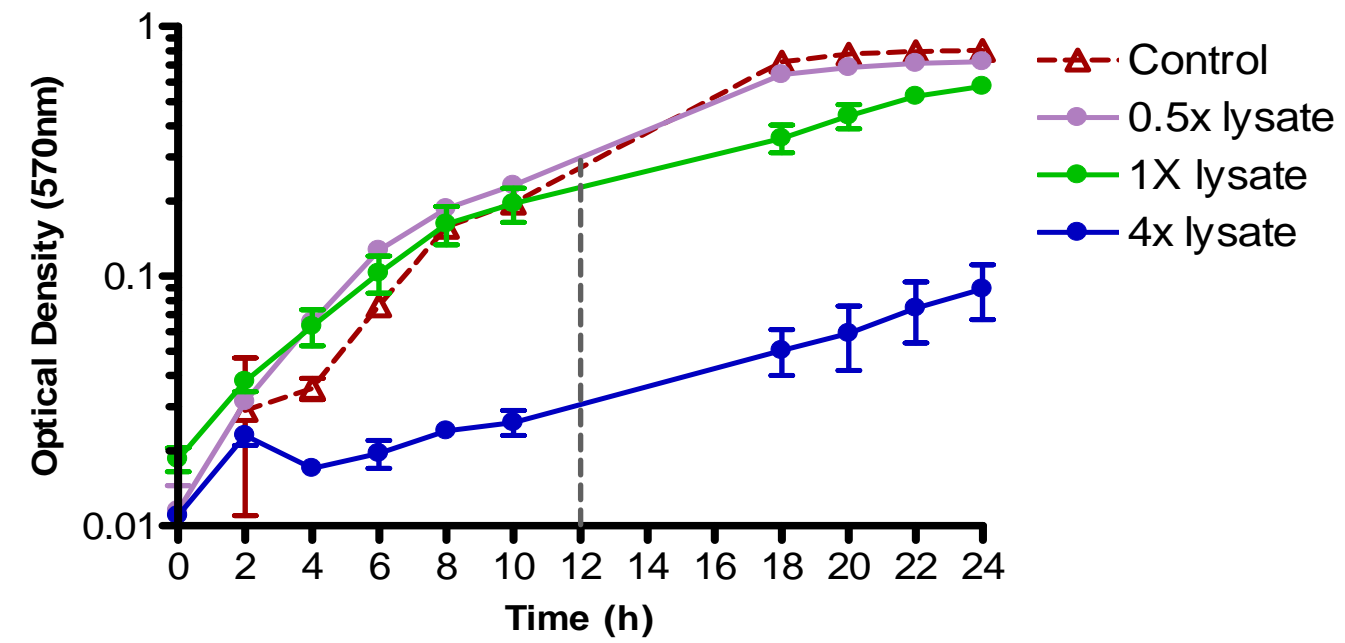

(a)

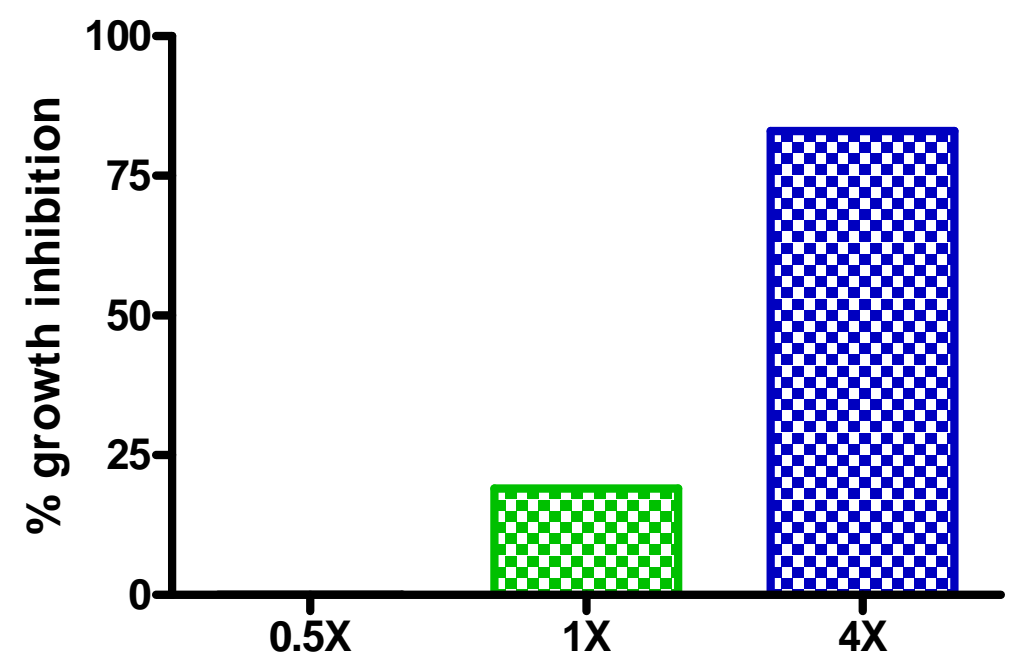

(b)

Figure 5 Antibacterial activity of diluted and concentrated samples of crude leukocyte lysate. (a) A twofold diluted sample, a crude lysate, and a four-fold concentrated sample of the same LL was added to $P$. citreus at a cell density of $2.5 \times 10^{4} \mathrm{CFU} / \mathrm{ml}$ and bacterial growth at $30^{\circ} \mathrm{C}$ was compared to corresponding control cultures consisting of $P$. citreus in the absence of lysate. Each point represents an average OD of samples from triplicate cultures. (b) Percent growth inhibition of a two-fold diluted sample, a crude lysate, and a four-fold concentrated sample of the same LL calculated at $12 \mathrm{~h}$. 


\section{Application of standard assay to titrate antibacterial activity in lysates}

To quantify the level of antibacterial activity present in samples, microdilution growth assays were set up using three different lysate preparations (lysate preps were from different blood samples, drawn at different times from different animals). Two-fold serial dilutions were made of each lysate in SCM and assayed for antibacterial activity, which was measured and expressed as percent growth inhibition calculated according to the formula:

$\%$ Inhibition $=\underline{\text { Final } \mathrm{OD}_{570 n m}} \underline{P \text {. citreus control }- \text { Final } \mathrm{OD}_{570 n m} \text { of test sample }} \times 100$ Final $\mathrm{OD}_{570 \mathrm{~nm}} P$. citreus control

where 'test sample' is $P$. citreus with test leukocyte lysate (LL).

Figure 6 shows that with increasing dilution of test lysate a corresponding decrease in antibacterial activity (measured as percent inhibition of $P$. citreus growth) is noted. The assay has sufficient sensitivity to detect antibacterial activity in crude lysate samples containing varying levels of antibacterial activity. Lysate sample, LL-1S was the least active lysate, while LL-3S showed the most antibacterial activity. The antibacterial activity titer of a lysate was taken as the inverse of the highest dilution that inhibited growth of $P$. citreus. Thus the antibacterial activity titer of LL-1S, 2S and 3S is 4, 8 and greater than 16, respectively. However, the growth inhibition detected below $20 \%$ may not be meaningful after an eight-fold dilution. 


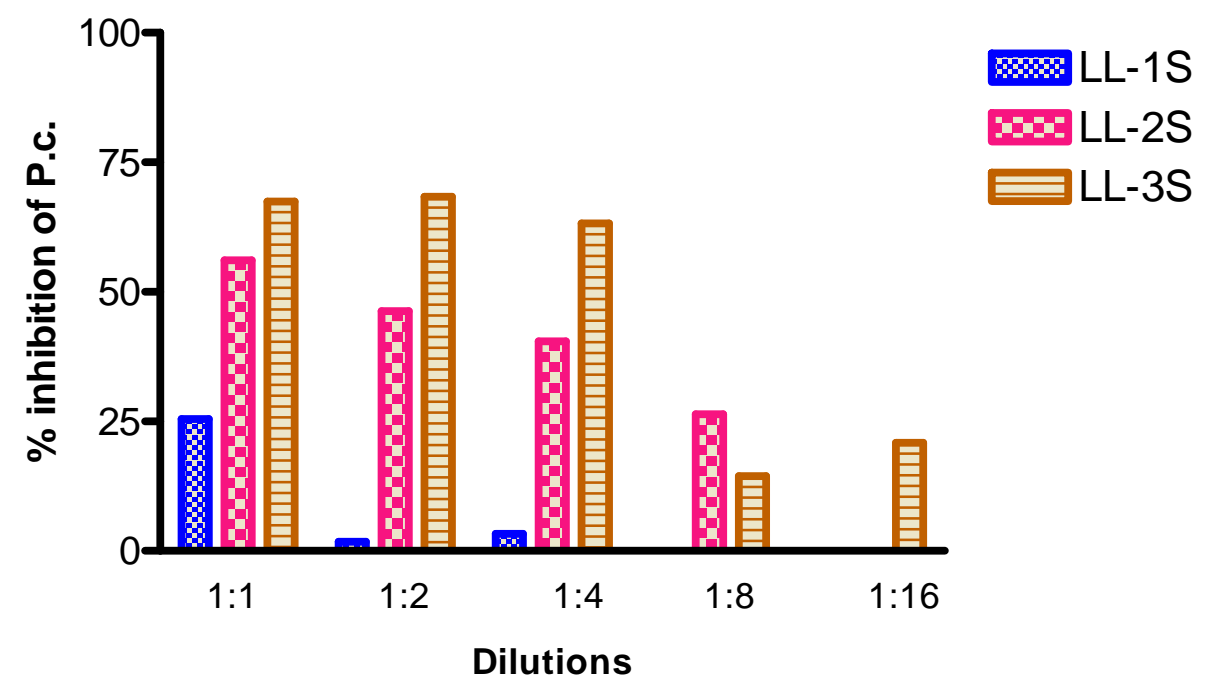

Figure 6 Variation in the antibacterial activity of different lysate preparations from different bleeds. Serial twofold dilutions of lysates, LL-1S, LL-2S and LL-3S were made in $2 x \mathrm{SCM}$. The assay was incubated at $30^{\circ} \mathrm{C}$ and assay end point $\mathrm{OD}_{570 \mathrm{~nm}}$ readings taken at $12 \mathrm{~h}$ in a Dynex ELISA reader. Each bar represents percent inhibition calculated from mean OD of duplicate cultures and compared to the control ( $P$. citreus in the absence of lysate).

\section{Fractionation of Cell Lysates and Protein Analysis of Active Fractions}

The initial screening of lysates for antibacterial activity was by the agar diffusion assay method. Lysates prepared by mechanical shearing, homogenization or sonication were fractionated by ion-exchange chromatography and several different permutations of chromatographic separation were employed. Column fractions were assayed for antibacterial and lysozyme activity. Fractions exhibiting antibacterial activity were further analyzed by SDS-PAGE analysis to determine protein composition and select protein bands were selected for amino acid sequence analysis.

Protocol I: DE Cellulose-Heparin

Protocol I consisted of a two step fractionation on DE cellulose, followed by affinity chromatography (Figure 7-9). Profiles of ion-exchange chromatography are illustrated in 
Figures 7 and 8 . Briefly, a lysate prepared by mechanical shearing using a glass

homogenizer was concentrated four-fold by ultra-filtration and applied to the first DE-52 cellulose column. Fractions were assayed for lysozyme and antibacterial activity. Most of the lysozyme activity was recovered in the pre-gradient fractions along with some antibacterial activity (Figure 7). Some lysozyme activity was also recovered in early post gradient fractions. Most of the antibacterial activity, however, was present in the postgradient fractions (Figure 7). The active fractions were pooled into 4 distinct pools consisting of the following fractions: Pool I (6-12), Pool II (70-77), Pool III (78-87), Pool IV (103-115) and Pool V (116-125). Pool I was concentrated by ultra-filtration and applied to a second DE cellulose column run under similar conditions to separate lysozyme from antibacterial activity. A similar elution profile to that of the first column was obtained (Figure 8) with lysozyme present in pre- and early post-gradient fractions, and with antibacterial activity separated and found in the later post-gradient fractions.

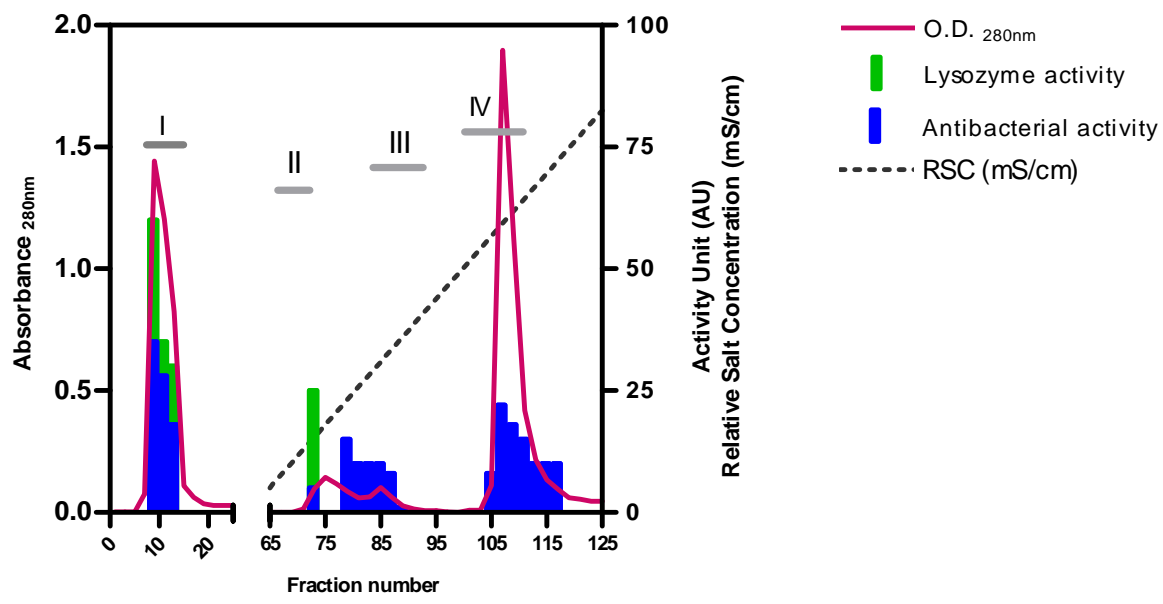

Figure 7 Protocol I: Fractionation of leukocyte lysate on DE Cellulose. Crude lysate $(2.5 \mathrm{ml})$ mixed with an equal volume of equilibration buffer was applied to DE-52 column $(1.0 \times 4.5 \mathrm{~cm})$ equilibrated with $0.02 \mathrm{M}$ Tris- $\mathrm{HCl}, \mathrm{pH} 7.5$. Fractions $(0.8 \mathrm{ml})$ were collected at a flow rate of $0.7 \mathrm{ml} / \mathrm{min}$ at $25^{\circ} \mathrm{C}$. Bound proteins were eluted from the column with a linear $\mathrm{NaCl}$ gradient, up to $0.9 \mathrm{M} \mathrm{NaCl}$. Antibacterial (blue bars) and lysozyme activity (green bars) were measured by agar diffusion for every other fraction and recorded as activity units (for details see Methods). 


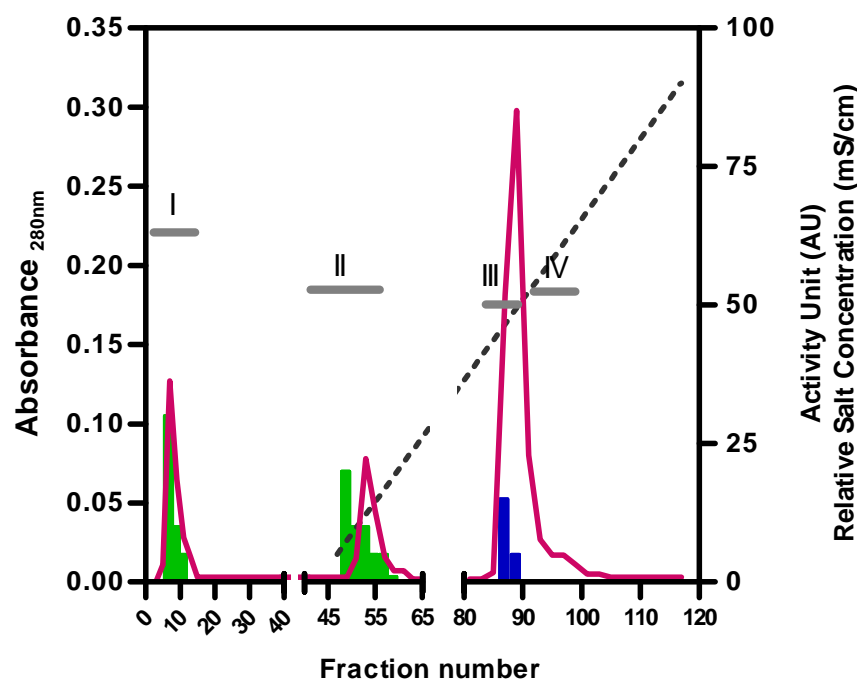

$$
\begin{aligned}
& \text { O.D. } 280 \mathrm{~nm} \\
& \text { Lysozyme activity } \\
& \text { Antibacterial activity } \\
& \text { RSC (mS/cm) }
\end{aligned}
$$

Figure 8 Protocol I: Fractionation of Pool I from the first DE Cellulose column. Crude lysate (2 ml) mixed with an equal volume of equilibration buffer was applied to DE-52 column $(1.0 \times 4.5 \mathrm{~cm})$ equilibrated with $0.02 \mathrm{M} \mathrm{Tris-HCl,} \mathrm{pH}$ 7.5. Fractions $(0.8 \mathrm{ml})$ were collected at a flow rate of $0.7 \mathrm{ml} / \mathrm{min}$ at $25^{\circ} \mathrm{C}$. Bound proteins were eluted from the column with a linear $\mathrm{NaCl}$ gradient, up to $0.9 \mathrm{M} \mathrm{NaCl}$. Antibacterial (blue bars) and lysozyme activity (green bars) was measured by agar diffusion for every other fraction and recorded as activity units (for details see Methods).

Active fractions of the second column were pooled into four pools: Pool I (6-12), Pool II (50-55), Pool III (84-89) and Pool IV (90-93). Pool IV and Pool III, containing most of the antibacterial activity from the first and second chromatographic separations, respectively, were combined and dialyzed against the equilibration buffer ( 100mM Tris$\mathrm{HCl}, 10 \mathrm{mM}$ citric acid, $225 \mathrm{mM} \mathrm{NaCl}, \mathrm{pH} 7.4)$ used for heparin affinity chromatography. Ten $\mathrm{ml}$ of the combined pool was applied to a heparin column (Figure 9a). Bound proteins were eluted by batch elution using buffers varying in salt concentration from $0.225 \mathrm{M}$ to $1.5 \mathrm{M} \mathrm{NaCl}$. Fractions were screened for antibacterial activity and active fractions were pooled (Fractions 79-89), concentrated five-fold and further analyzed by SDS-PAGE analysis (Figure 9b). Proteins were subsequently transferred to a PVDF membrane for sequence analysis. An SDS-PAGE gel stained with coomassie blue 
revealed two distinct protein bands between 6 and $14 \mathrm{kDa}$ (Figure 9b). Protein bands were subjected to Edman Degradation for $\mathrm{N}$-terminal protein sequencing (performed by University of Florida Protein Core). The upper band ( 14 kDa) generated an N-terminal sequence of 14 residues with homology to teleost histone, H2B (see Table 5 below). The lower band ( $\sim \mathrm{kDa})$ generated an $\mathrm{N}$-terminal sequence of 14 residues with homology to teleost histone, H2A (see Table 5 below). Pool I, which contained only lysozyme activity, from the second chromatographic separation was similarly loaded onto a heparin affinity column, but no bound protein was eluted (profile not shown).

Protocol IIA: DE Sepharose-glass homogenized lysate

An alternative fractionation protocol consisted of a single fractionation step on DE Sepharose. A leukocyte lysate was prepared by mechanical shearing and concentrated ten-fold by using a combination of vacuum centrifugation and ultra-filtration (membrane cut-off MWCO, 3.5kDa). The sample $(800 \mu \mathrm{l}$ ) was dialyzed against the column equilibration buffer (0.02M Tris- $\mathrm{HCl}, \mathrm{pH} 7.5)$ and applied to a DE Sepharose column. Bound proteins were eluted with a linear gradient, up to $0.9 \mathrm{M} \mathrm{NaCl}$ (Figure 10a). Pre- and post-gradient fractions showing peak antibacterial activity were pooled. Pre-gradient and early post-gradient fractions, Pool I (9-19) and Pool III (61-75) contained antibacterial, along with lysozyme activity which was absent from the later post-gradient fractions, Pool IV (95-107) and Pool V (108-121) that contained only antibacterial activity. Control assays testing elution buffers corresponding to the salt concentration at the end of the gradient showed inhibition of growth. Therefore, Pool V 
was not processed further since growth inhibition was attributed to the presence of

high salt and not protein.

(a)

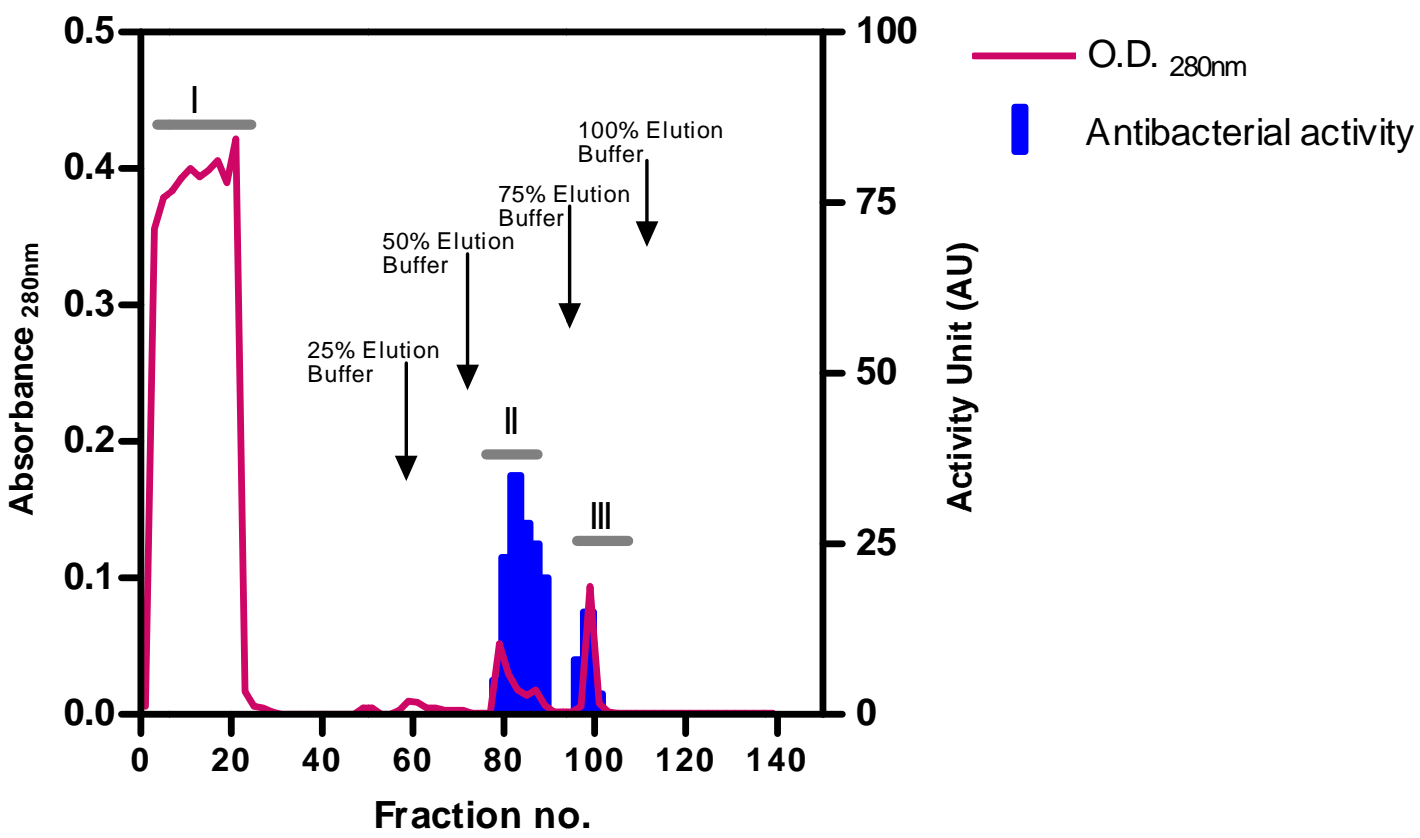

Figure 9 Protocol I: Fractionation of the combined pools from two DE Cellulose columns (see text) on Heparin Affinity column and SDS-PAGE analysis. (a) Combined pooled sample $(10 \mathrm{ml})$ was applied to Heparin Affinity column $(0.7 \times 2.5 \mathrm{~cm})$ equilibrated with $100 \mathrm{mM}$ Tris- $\mathrm{HCl}, 10 \mathrm{mM}$ citric acid, $225 \mathrm{mM} \mathrm{NaCl}, \mathrm{pH} 7.4$. Fractions $(0.5 \mathrm{ml})$ were collected at a flow rate of $0.75 \mathrm{ml} / \mathrm{min}$ at $25^{\circ} \mathrm{C}$. Bound proteins were eluted step-wise using equilibration buffer diluted $25 \%, 50 \%, 75 \%$ and $100 \%$ with elution buffer (100mM Tris- $\mathrm{HCl}, 10 \mathrm{mM}$ citric acid, $1.5 \mathrm{M} \mathrm{NaCl}, \mathrm{pH} 7.4)$. Antibacterial activity (blue bars) was measured by agar diffusion for every other fraction and recorded as activity units (for details see Methods). Post-gradient fractions (fr 79-89) were pooled (Pool II) and analyzed by SDS-PAGE (b) Lanes 2 through 6 contained $\beta$ mercapto-ethanol reduced samples of Pool II. Molecular weight standard (MWS) (Bio-Rad Broad Range) was run in lane \# 1. 
Pool IV (fractions 95-107) was concentrated ten-fold by ultra-filtration (MWCO 3.5kDa). Pool IV was further analyzed for protein composition using SDS-PAGE analysis (Figure 10b). Proteins from the gel were subsequently transferred to a PVDF membrane for sequence analysis. The lowest band ( $6 \mathrm{kDa}$ ) was subjected to Edman Degradation for protein sequencing (University of Florida Protein Core). The protein band generated an $\mathrm{N}$-terminal amino acid sequence of 12 residues with homology to teleost and mammalian histone, H2A (see Table 5 below). The upper bands were also sequenced but yielded amino acid sequences with no significant homology.

Table 5 N-terminal Amino Acid Sequence of Proteins Isolated from Shark Leukocyte Lysate Analyzed by Edman Degradation

\begin{tabular}{llll}
\hline Sample & Band & Sequence & ID \\
\hline $\begin{array}{l}\text { Pool II- Heparin Affinity } \\
\text { (Protocol I) }\end{array}$ & Upper & KGAKKRSRSRKEXY & Histone H2B \\
$\begin{array}{l}\text { Pool II -Heparin Affinity } \\
\text { (Protocol I) }\end{array}$ & Lower & SIAISRSYRAGLQF & Histone H2A \\
$\begin{array}{l}\text { Pool IV-DE Sepharose (Protocol } \\
\text { IIA) }\end{array}$ & Lower & SRSERAGLQFQK & Histone H2A \\
\hline
\end{tabular}




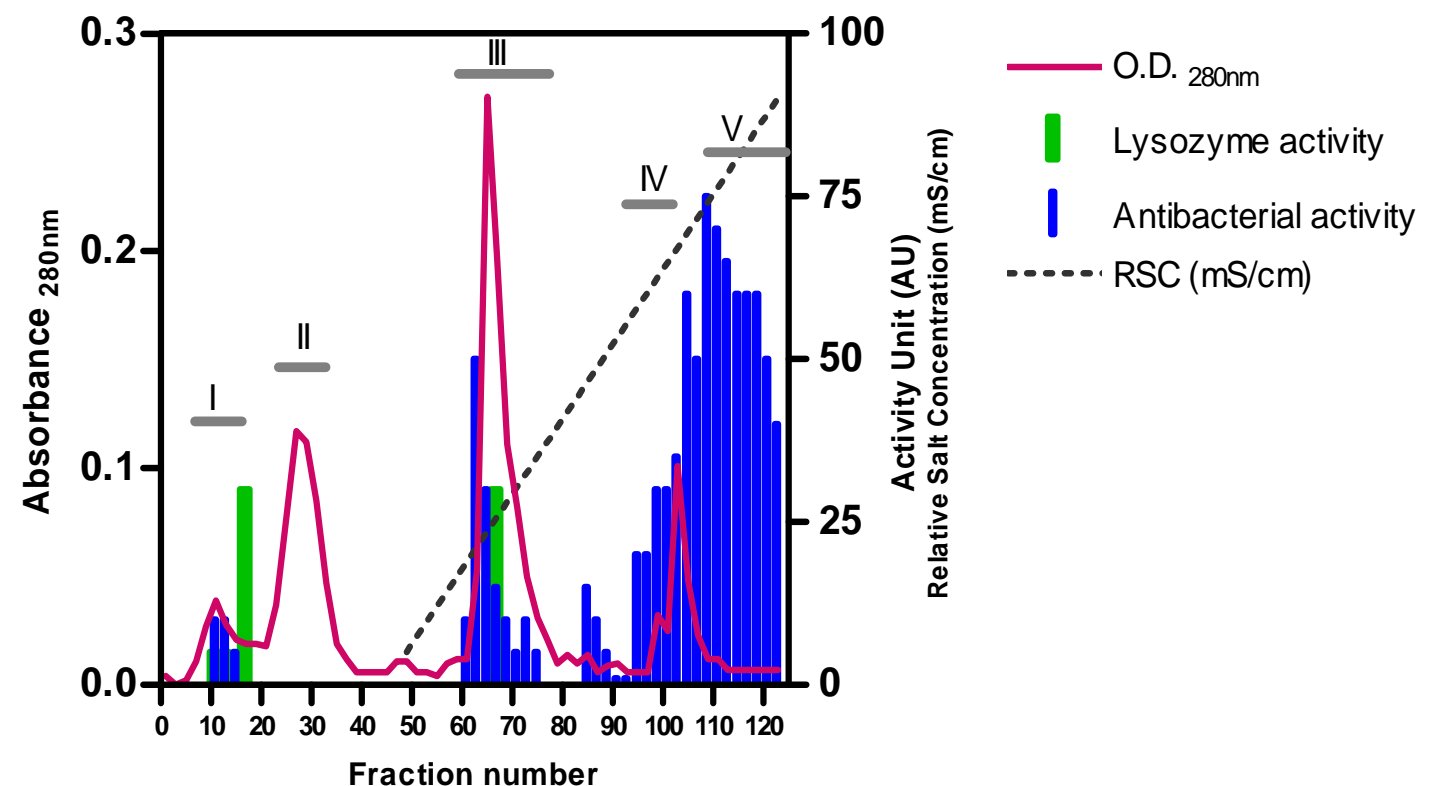

(a)

(b)

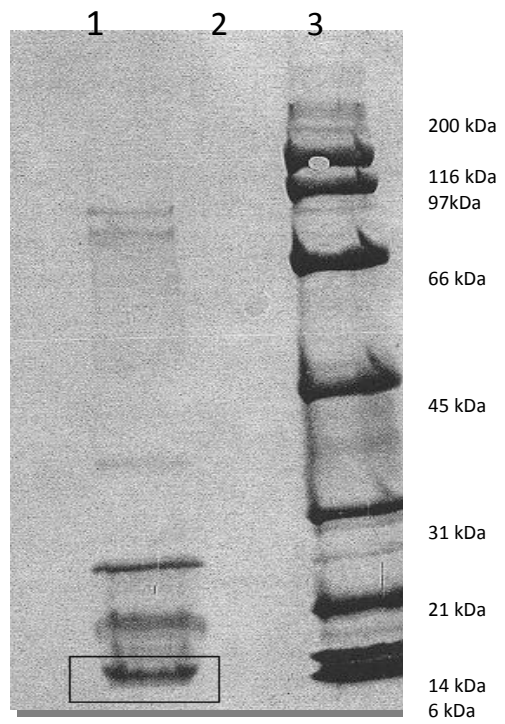

Figure 10 Protocol IIA: Fractionation of leukocyte lysate on DE Sepharose and SDS-PAGE analysis. (a) Crude lysate $(0.8 \mathrm{ml})$ mixed with an equal volume of equilibration buffer was applied to DE Sepharose column $(1.0 \times 4.5 \mathrm{~cm})$ equilibrated with $0.02 \mathrm{M}$ Tris- $\mathrm{HCl}, \mathrm{pH} 7.5$. Fractions $(0.5 \mathrm{ml})$ were collected at a flow rate of $0.5 \mathrm{ml} / \mathrm{min}$ at $25^{\circ} \mathrm{C}$. Bound proteins were eluted with a linear $\mathrm{NaCl}$ gradient, up to $0.9 \mathrm{M} \mathrm{NaCl}$. Antibacterial (blue bars) and lysozyme activity (green bars) was measured by agar diffusion for every other fraction and recorded as activity units (for details see Methods). Post-gradient fractions (95-107, pool IV) were pooled, concentrated ten-fold and analyzed by SDSPAGE. (b) Lane 1 contained Pool IV. Lane 2 contained sample buffer only. Molecular weight standard (MWS) (Bio-Rad Broad Range) was run in lane \# 3. 


\section{Fractionation of Cell Lysates and Correlation of Antibacterial Activity with Specific}

\section{Protein Bands}

Since histone fragments and other types of protein fragments and peptides have been shown in other species to have antibacterial activity, experiments were performed to determine whether antibacterial activity could be correlated to specific protein band(s) and to show whether the shark histone fragments identified were antibacterial. Thus, subsequent fractionation was carried out employing similar chromatographic conditions (see above) with minor modifications to buffers. Also fractions were screened for antibacterial activity using the standard microdilution growth assays in place of the agar diffusion assay. In addition, lysates were prepared by sonication rather than mechanical shearing and/or homogenization, since a higher level of activity was recovered in the sonicated lysate. Several DE Sepharose columns were run either singly or in series to fractionate the leukocyte lysates. To correlate antimicrobial activity with a specific protein/peptide, active fractions and/or pools were subjected to the acid-urea gel overlay protocol.

Protocol IIB: DE Sepharose-sonicate lysate I

A leukocyte lysate prepared by sonication of leukocytes and concentrated five-fold

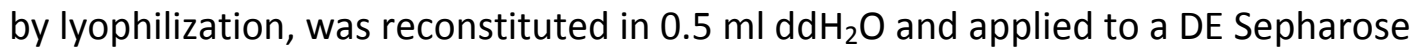
column. Figure 11 shows the chromatographic profile yielding two major protein peaks, a pre-gradient and post-gradient peak. Every other fraction was assayed for antibacterial activity using the microdilution growth assay and antibacterial activity was 
present in both pre-gradient and post-gradient fractions. The peak activity fractions were further analyzed for protein composition using SDS-PAGE.

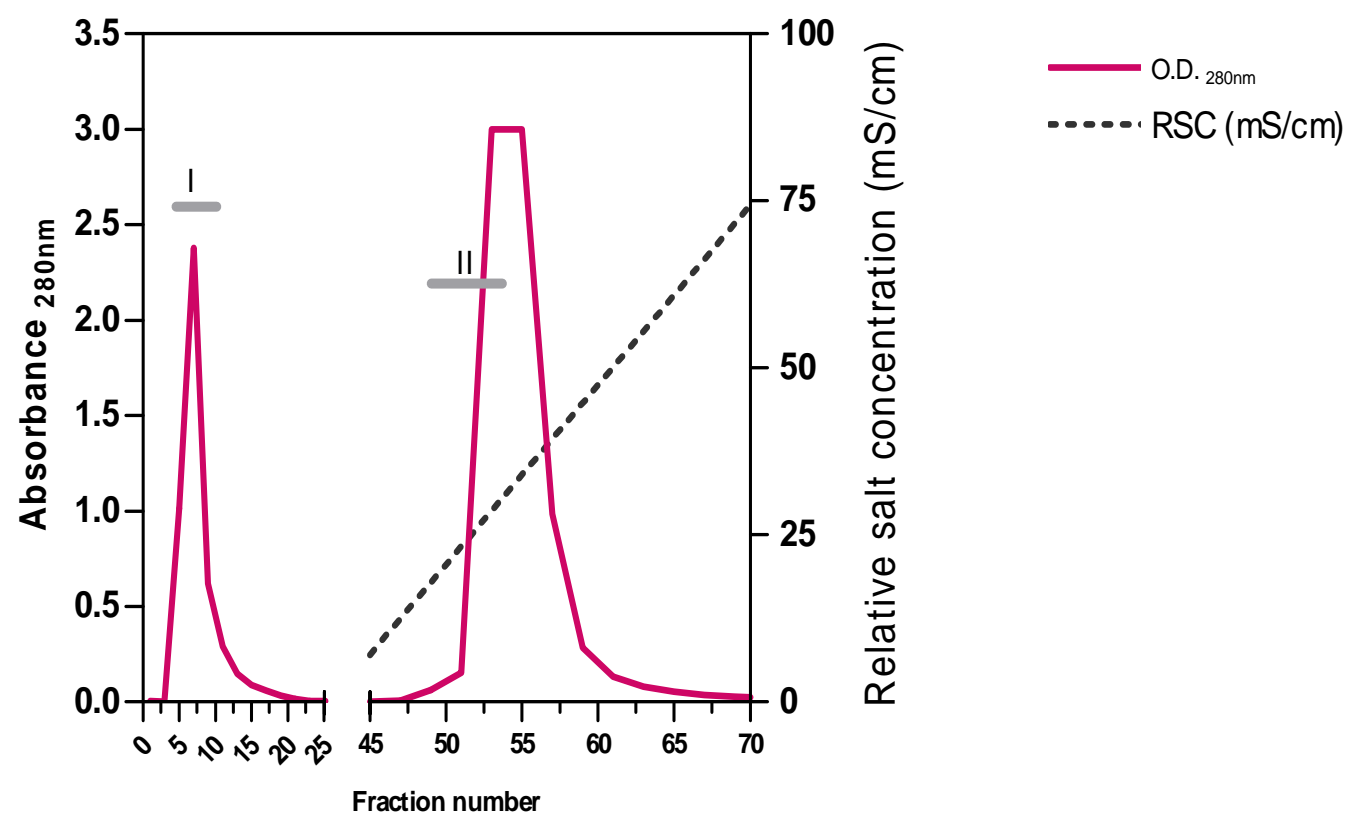

Figure 11 Protocol IIB: Fractionation of lysate on DE Sepharose column. A five-fold concentrated crude lysate $(0.5$ $\mathrm{ml}$ ) mixed with equilibration buffer $(0.3 \mathrm{ml})$ was applied to DE Sepharose column $(1.0 \times 4.5 \mathrm{~cm})$ equilibrated with $0.02 \mathrm{M}$ Tris- $\mathrm{HCl}, 0.05 \mathrm{M} \mathrm{NaCl}, \mathrm{pH} 7.5$. Fractions $(1 \mathrm{ml})$ were collected at a flow rate of $1 \mathrm{ml} / \mathrm{min}$ at $25^{\circ} \mathrm{C}$. Bound proteins were eluted from the column with a linear $\mathrm{NaCl}$ gradient, up to $0.9 \mathrm{M} \mathrm{NaCl}$.

Fractions 4-9 were pooled (Pool I), concentrated ten-fold by lyophilization, and subjected to acid-urea gel electrophoresis and analyzed for antibacterial activity by applying to a lawn of target organisms (acid-urea overlay). Distinct zones of inhibition were seen in the seeded lawn (Figure 12a) corresponding to the position of protein bands in the AU transfer gel. The acid-urea transfer gel stained with coomassie blue (Figure 12b), shows residual protein remaining after transfer of the 'active' protein to the agar overlay plate seeded with $P$. citreus. The position of residual protein bands correlates with the zone of inhibition noted on acid-urea overlay agar plate. 
1

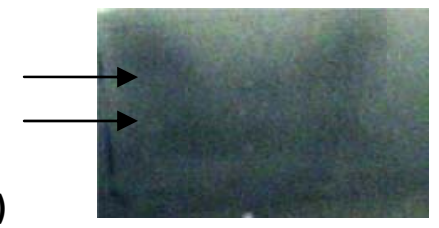

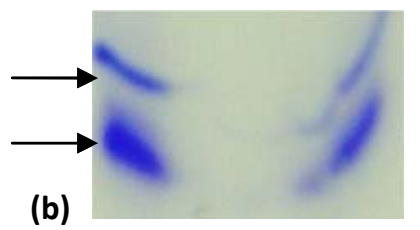

Figure 12 Acid-Urea PAGE analysis of concentrated Pool I (Protocol IIB). (a) Concentrated Pool I, from Protocol IIB in lane 1, was loaded onto a pre-run gel and electrophoresed. Gel was washed in $10 \mathrm{mM}$ phosphate buffer $\mathrm{pH} 7.5$ and overlaid on agar seeded with Planococcus citreus and incubated $3 \mathrm{~h}$ at $30^{\circ} \mathrm{C}$. Gel was removed and SCM poured on top and allowed to solidify. Plates were incubated overnight at $30^{\circ} \mathrm{C}$. (b) Acid-Urea transfer gel. Transfer gel was removed from seeded agar and stained with coomassie brilliant blue R-250 for $1 \mathrm{~h}$ and destained overnight to confirm that protein had transferred to the agar. Residual protein remained in the gel, however most protein was transferred. The position of the partial protein bands correlated to the position where inhibition zones were noted in the agar.

Pool I was further analyzed for protein composition using SDS-PAGE analysis. Protein bands were subsequently excised from the gel for sequence analysis (Figure 13a). The intense band ( $20 \mathrm{kDa}$ ) was subjected to trypsin digest, followed by LC-MS/MS analysis (performed by University of Florida Protein Core). The protein band generated an internal amino acid sequence of three unique fragments, 9, 13 and 16 residues long with homology to human polyubiquitin (Table 6). An attempt was made to further separate the intense band by using a gel with a smaller pore size, 12\% (Figure 13b) vs. $8 \%$ (Figure 12a). The resulting gel showed two distinct lower bands, similar to the bands seen in the acid urea gel, Figure 13b, these lower bands were excised (Figure 13, arrows), and sent for trypsin digest and LC-MS/MS analysis. Band 1 yielded a unique 6 residue fragment with sequence homology to ubiquitin from the catshark (see Table 6). Band 2 yielded a 5 residue fragment with sequence similarity to nurse shark nucleoside diphosphokinase, but had less than $80 \%$ probability and only one unique peptide. 
Protocol IIC-1: DE Sepharose-sonicate lysate II

Another leukocyte lysate prepared by sonication and concentrated three-fold by

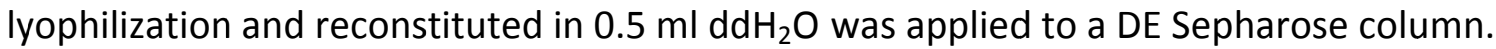
The chromatographic profile (Figure 14) shows three protein peaks, a pre-gradient and two post-gradient peaks.

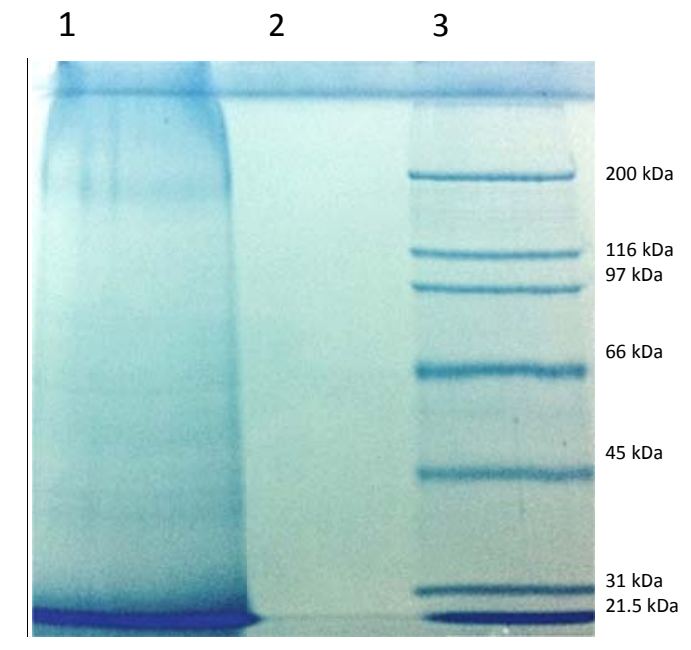

(a)

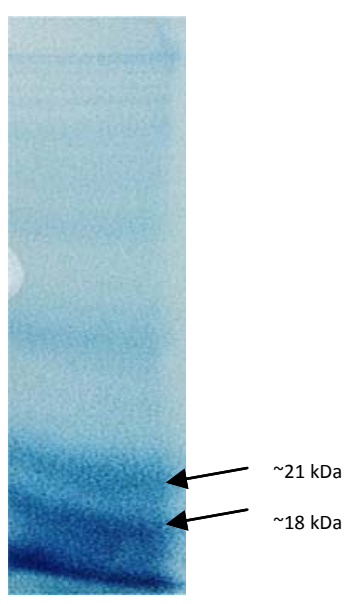

(b)

Figure 13 SDS-PAGE Analysis of Pool I from DE Sepharose column (Protocol IIB). Fractions were analyzed using SDS-PAGE. (a) Pool I (DE Sepharose-Protocol III) was run on an $8 \%$ gel in lane 1 , and the molecular weight standard (MWS) (Bio-Rad Broad Range) was run in lane \# 3. Lane 2 was left blank. (b) Pool I (DE Sepharose-Protocol III) was run on a $12 \%$ gel with the molecular weight labeled beside each gel.

Fractions were assayed for antibacterial activity using the microdilution growth assay and antibacterial activity was present in both pre-gradient and post-gradient peak fractions. The peak fractions were further analyzed for protein composition using SDSPAGE analysis (Figure 15).

Active fractions were pooled, Pool I (fractions 5-11), Pool II ( fractions 19-39), Pool III (57-67) and Pool IV (89-105), concentrated by lyophilization, and following acid-urea gel 
electrophoresis, were analyzed for antibacterial activity by applying to a lawn of $P$.

citreus (acid-urea overlay). Distinct zones of inhibition were seen in the seeded lawn for pools I, II and IV, although growth of $P$. citreus was sparse. Zones of growth inhibition are shown in Figure 16. A tandem gel run simultaneously as the gel used to overlay the seeded agar was stained with coomassie blue (Figure 16a) to show position of protein bands occurring on the gel. LC-MS/MS analysis could not be performed on these samples because of contamination of the pools resulting from loss of refrigeration upon storage.
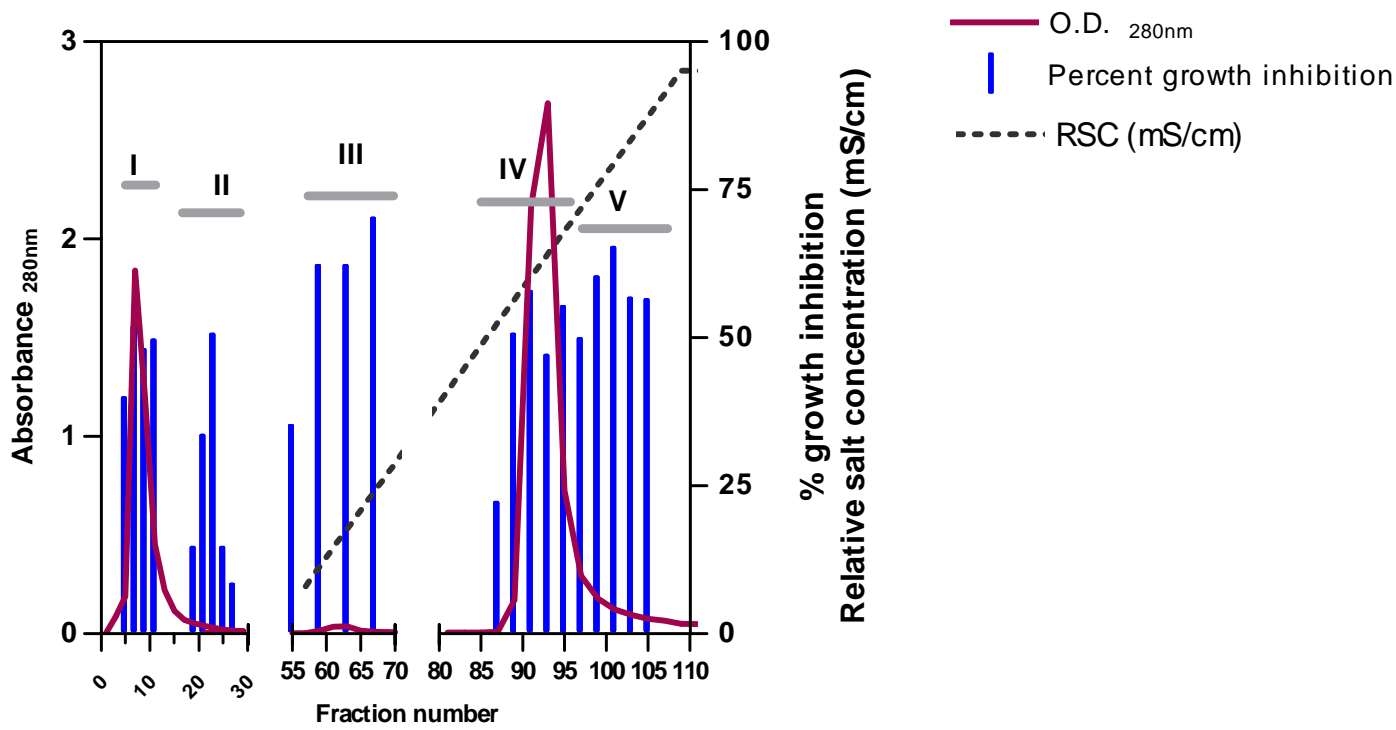

Figure 14 Protocol IIC-1: Fractionation of lysate on DE Sepharose column. Concentrated crude lysate (0.4 ml) mixed with equilibration buffer $(0.1 \mathrm{ml})$ was applied to $D E$ Sepharose column $(1.0 \times 4.5 \mathrm{~cm})$ equilibrated with $0.02 \mathrm{M}$ Tris- $\mathrm{HCl}, 0.05 \mathrm{M} \mathrm{NaCl}, \mathrm{pH} 7.5$. Fractions $(1 \mathrm{ml})$ were collected at a flow rate of $1 \mathrm{ml} / \mathrm{min}$ at $25^{\circ} \mathrm{C}$. Bound proteins were eluted from the column with a linear $\mathrm{NaCl}$ gradient, up to $0.9 \mathrm{M} \mathrm{NaCl}$. Antibacterial activity (blue bars) was measured by microdilution growth assays for all fractions tested and recorded as percent growth inhibition (for details see Methods). 


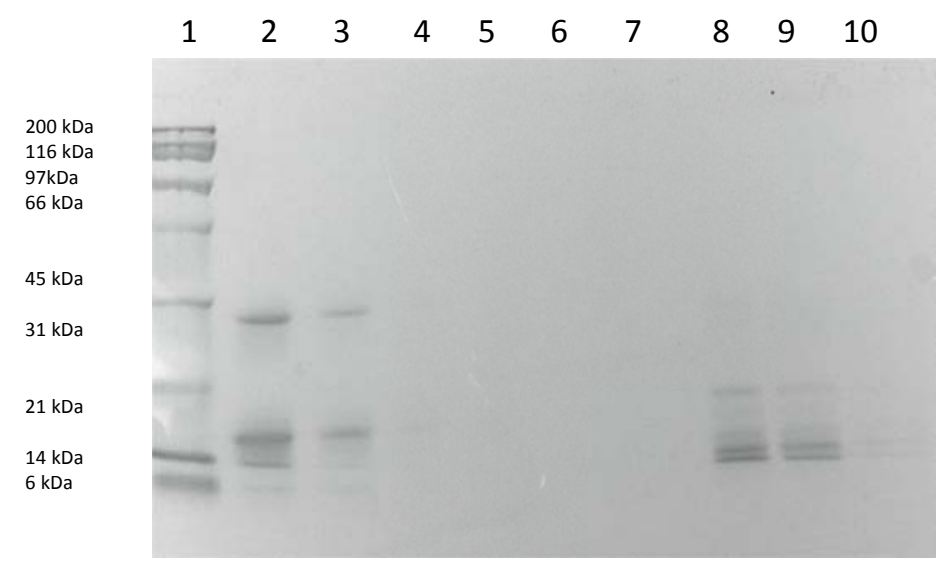

Figure 15 SDS-PAGE analysis of fractions from DE Sepharose column (Protocol IIC-1). Peak fractions were analyzed by SDS-PAGE. Molecular weight standard (MWS) (Bio-Rad Broad Range) was run in lane \# 1. Lanes 2 to 10 contained fractions $7,9,11,13,63,65,91,93,95$ respectively.

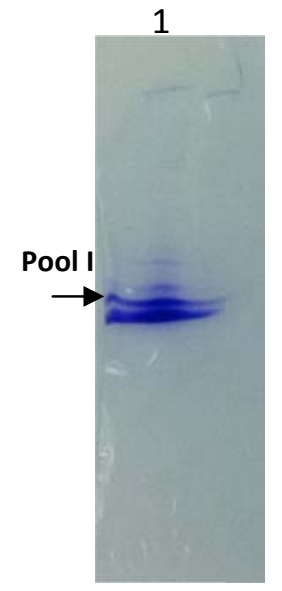

(a)

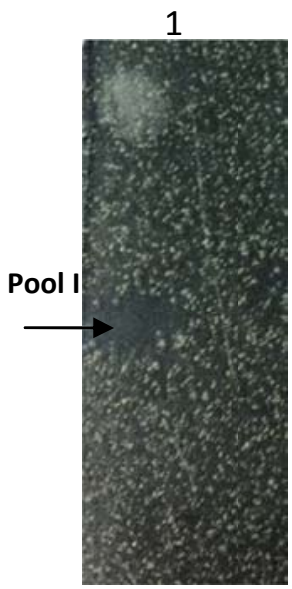

(b)

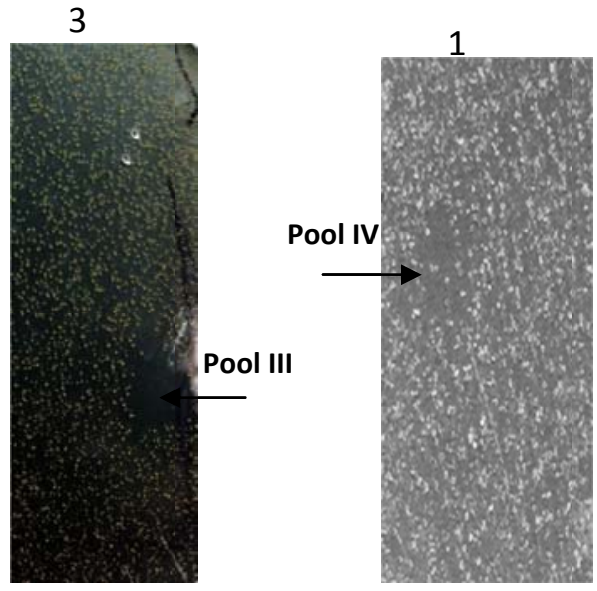

(c)

(d)

Figure 16 Acid-Urea PAGE analysis of concentrated pools of DE Sepharose (Protocol IIC-1). (a) Coomassie blue stained tandem run gel showing protein composition of the sample. All samples were electrophoresed on pre-run gels, washed in $10 \mathrm{mM}$ phosphate buffer $\mathrm{pH} 7.5$ and overlaid on the agar seeded with Planococcus citreus and incubated $3 \mathrm{~h}$ at $30^{\circ} \mathrm{C}$. Gel was removed and SCM poured on top and allowed to solidify. Plates were incubated overnight at $30^{\circ} \mathrm{C}$. Pools I (b), Pool III (c) and Pool IV (d), showed zones of inhibition. Zone of inhibition of Pool I corresponded to protein band seen on coomassie blue stained tandem gel. Pool II and IV (not shown) showed no zones of inhibition.

The zone of inhibition seen with Pool I on the acid urea gel (Figure 16b) correlated to protein bands seen on coomassie blue stained tandem gel. Pool II and IV (not shown) showed no zones of inhibition. Pool IV (89-105) from DE Sepharose (Protocol IV) was 
concentrated fifty-fold by lyophilization and reconstituted in $\mathrm{ddH}_{2} \mathrm{O}$. This sample was applied to a second DE Sepharose column run under similar conditions. Antibacterial activity was recovered post-gradient, with an increasing $\mathrm{NaCl}$ gradient (Figure 17). Although there is antibacterial activity, it is at a low level (below 20\%), so it is difficult to distinguish the actual level of activity with these fractions that elute with high salt concentration. Peak activity fractions were pooled, lyophilized and reconstituted in $\mathrm{ddH}_{2} \mathrm{O}$ and analyzed by SDS-PAGE and acid-urea gel electrophoresis. The lawn of target organism showed no zones of growth inhibition within the area subjected to acid-urea gel overlay, although a zone of inhibition was noted around the control antimicrobial peptide, HNP1 (a $\beta$-defensin).

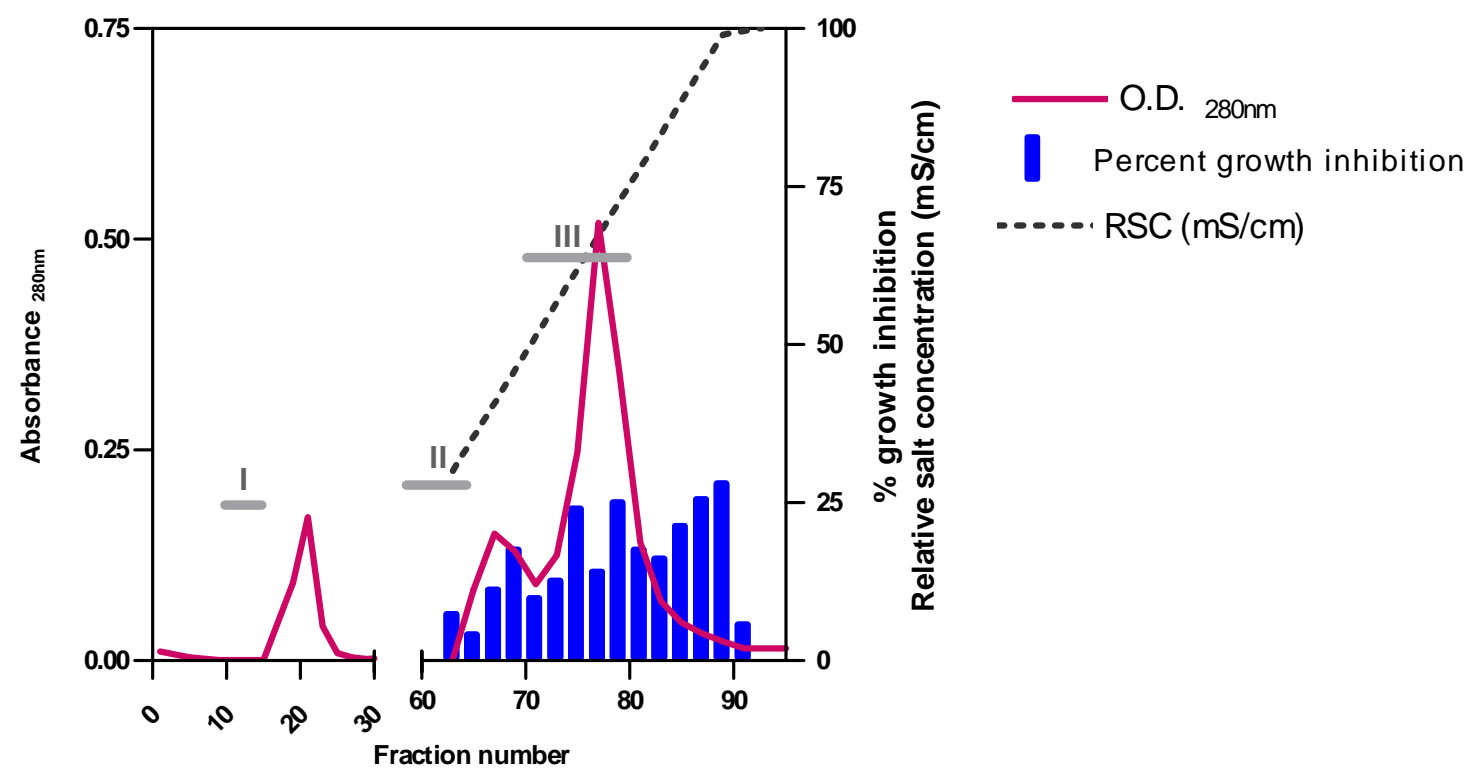

Figure 17 Protocol IIC-1: Fractionation of Pool IV from first DE Sepharose column. Pool IV (0.5 ml) mixed with an equal volume of equilibration buffer was applied to a second DE Sepharose column $(2.5 \times 4.5 \mathrm{~cm})$ equilibrated with $0.02 \mathrm{M}$ Tris- $\mathrm{HCl}, 0.05 \mathrm{M} \mathrm{NaCl}, \mathrm{pH} 7.5$. Fractions $(1 \mathrm{ml})$ were collected at a flow rate of $1 \mathrm{ml} / \mathrm{min}$ at $25^{\circ} \mathrm{C}$. Bound proteins were eluted from the column with a linear $\mathrm{NaCl}$ gradient, up to $0.9 \mathrm{M} \mathrm{NaCl}$. Antibacterial activity (blue bars) was measured by microdilution growth assay for all fractions tested and recorded as percent growth inhibition (for details see Methods). 


\section{Protocol IIC-2: DE Sepharose-sonicated lysate III}

To improve separation and recovery of antibacterial activity the protocol for ion exchange chromatography was modified by the application of a step-wise elution gradient. A leukocyte lysate concentrated five-fold by lyophilization and reconstituted in $1 \mathrm{ml} \mathrm{ddH_{2 }} \mathrm{O}$ was applied to a DE Sepharose column and eluted with a two step linear $\mathrm{NaCl}$ gradient (Gradient 1-0.05M NaCl to $0.5 \mathrm{M} \mathrm{NaCl}$; Gradient 2- $0.5 \mathrm{M} \mathrm{NaCl}$ to $1.0 \mathrm{M}$ $\mathrm{NaCl}$ ). The chromatographic profile (Figure 18) shows four protein peaks, a pre-gradient and three post-gradient peaks. Fractions were assayed for antibacterial activity using the agar diffusion assay and antibacterial activity was present in the pre-gradient and post-gradient peak fractions. The fractions showing high antibacterial activity were further analyzed for protein composition by SDS-PAGE (Figure 19).

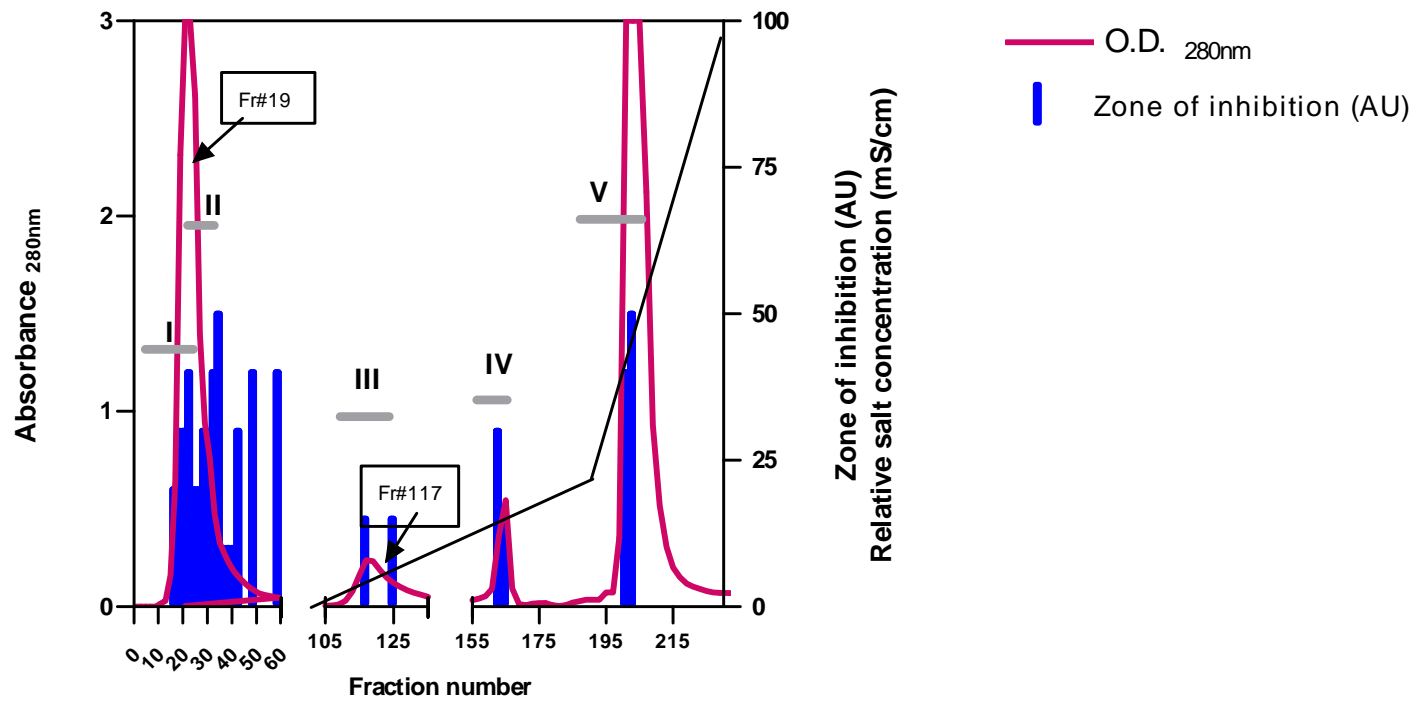

Figure 18 Protocol IIC-2: Fractionation of lysate on DE Sepharose column. Concentrated crude lysate $(0.7 \mathrm{ml})$ mixed with equilibration buffer $(0.3 \mathrm{ml})$ was applied to DE Sepharose column $(2.5 \times 4.5 \mathrm{~cm})$ equilibrated with $0.02 \mathrm{M}$ Tris- $\mathrm{HCl}, 0.05 \mathrm{M} \mathrm{NaCl}, \mathrm{pH} 7.5$. Fractions $(1 \mathrm{ml})$ were collected at a flow rate of $1 \mathrm{ml} / \mathrm{min}$ at $25^{\circ} \mathrm{C}$. Bound proteins were eluted from the column with a step-wise $\mathrm{NaCl}$ gradient (Gradient 1-0.5M NaCl; Gradient 2-1.0M NaCl). Antibacterial activity (blue bars) was measured by agar diffusion assay for all fractions tested and recorded as activity units (for details see Methods). 
$\begin{array}{llllll}1 & 2 & 3 & 4 & 5 & 6\end{array}$

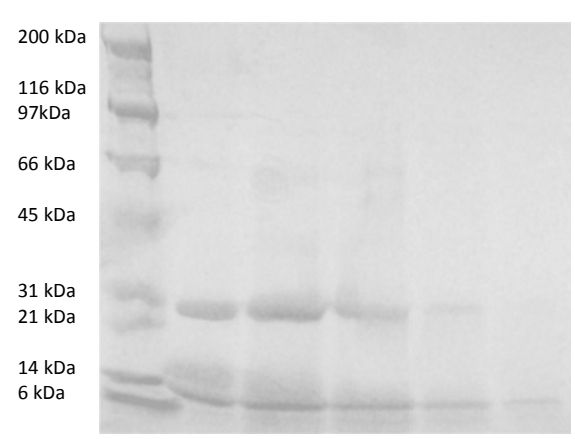

(a)

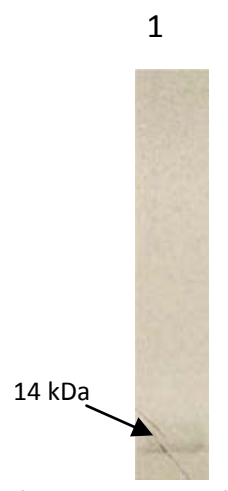

(b) $\begin{array}{llllllll}1 & 2 & 3 & 4 & 5 & 6 & 7 & 8\end{array}$

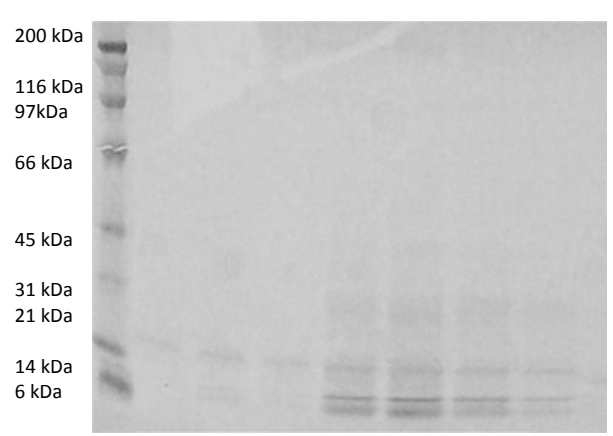

(c)

Figure 19 SDS-PAGE analysis of fractions from DE Sepharose column (Protocol IIC-2). Peak fractions were analyzed by SDS-PAGE. For each gel molecular weight standard (MWS) (Bio-Rad Broad Range) was run in lane \# 1. (a) Lanes 2 to 6 contained fractions 17,19, 21 ,23,25 (of Pool I), respectively. (b) Lane 1 contained fraction 117 (of Pool III). (c) Lanes 2 to 8 contained fractions 163,165 (of Pool IV),199, 201, 203, 205, 207 (of Pool V), respectively.

Fractions 19 and 117 were also subjected to $\mathrm{AU}$ gel electrophoresis, and then applied to a lawn of target organisms for antibacterial activity. For both fractions, distinct zones of inhibition were seen in the seeded lawn (Figure20).

Peak fractions were pooled, Pool I (16-24), lyophilized, reconstituted in $\mathrm{dd}_{2} \mathrm{O}$ and subjected to acid-urea electrophoresis and analyzed for antibacterial activity by overlay on seeded agar (Figure 21a). A tandem gel run under the same conditions as the gel used to overlay the seeded agar was stained with coomassie blue (Figure $21 \mathrm{~b}$ ). The protein bands correlated with the position of growth inhibition zones noted in the agar overlay (Figure 21a and b).

Pool III (115-121), which included active fraction 117, was chosen to be subjected to LC-MS/MS analysis. The excised band was sent to the University of Florida Protein Core and yielded two unique fragments with a total of 28 residues with sequence homology to Chain A of Hen egg white lysozyme, HEWL (see Table 6). 
Fraction 19

(a)

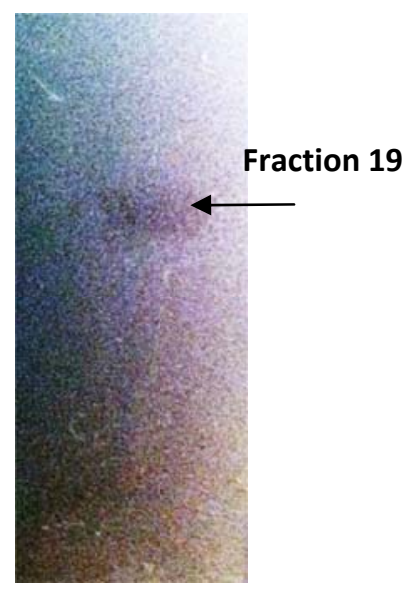

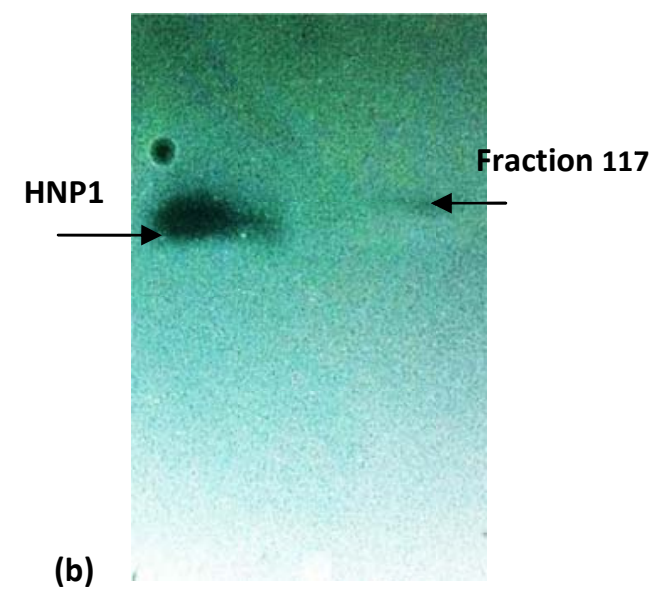

(b)

Figure 20 Acid-Urea Gel analysis of fractions from DE Sepharose (Protocol IIC-2). Overlay showing zone of inhibition with fractions from lysate from DE Sepharose. (a) Fraction 19 (lane 1), (b) HNP1 (25 $\mathrm{kg} / \mathrm{ml}$ ) lane 1, Fraction 117 (lane 2), were loaded onto pre-run gel and once electrophoresed, were washed in $10 \mathrm{mM}$ phosphate buffer $\mathrm{pH}$ 7.5 and overlaid on the agar seeded with Planococcus citreus and incubated $3 \mathrm{~h}$ at $30^{\circ} \mathrm{C}$. Gel was removed and SCM poured on top and allowed to solidify. Plates were incubated overnight at $30^{\circ} \mathrm{C}$.

(a)

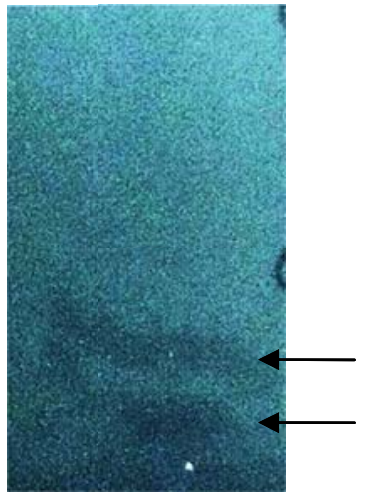

(b)

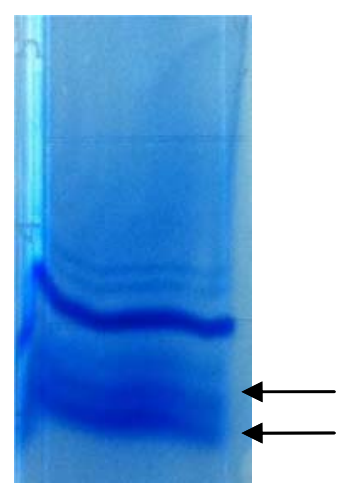

Figure 21 Acid-Urea Gel analysis of Pool I (Protocol IIC-2). Overlay showing zone of inhibition with concentrated pools from DE Sepharose Pool I. (a) Pool I (lane 1), was loaded onto pre-run gel and once electrophoresed, gels were washed in $10 \mathrm{mM}$ phosphate buffer pH 7.5 and overlaid on the agar seeded with Planococcus citreus and incubated 3 $\mathrm{h}$ at $30^{\circ} \mathrm{C}$. Gel was removed and $\mathrm{SCM}$ poured on top and allowed to solidify. Plates were incubated overnight at $30^{\circ} \mathrm{C}$. (b) Acid -urea tandem gel showing band corresponding to zone of inhibition. Tandem gel was run simultaneously as gel used for overlay and directly stained in coomassie brilliant blue R-250 for $1 \mathrm{~h}$ and destained overnight. 
Table 6 Internal Amino Acid Sequence Analysis of Proteins Isolated from Shark Leukocyte Lysates Analyzed by LC-MS/MS

\begin{tabular}{llll}
\hline Sample & Band & Sequence & ID \\
\hline Pool I-DE Sepharose (Protocol IIB) & Band 1 & TITLQVEPSDTIENVK & Polyubiquitin \\
& & IQDKEGIPPDQQR & \\
Pool I-DE Sepharose (Protocol IIB) & Band 1 & LIFAGK & Ubiquitin \\
& & & Chain A, HEWL \\
Pool III-DE Sepharose (Protocol IIC-2) & Band 1 & FESNFNTQATNR & \\
& & NTDGSTDYGILQINSR & \\
\hline
\end{tabular}

\section{Western Blot Analysis}

Western blot analysis of pools was performed to determine whether histones and lysozyme could be detected using heterologous antisera such as rabbit polyclonal antibodies to human histones $\mathrm{H} 2$ and $\mathrm{H} 4$ and antibodies to hen egg white lysozyme (HEWL) as the primary antibodies. Goat anti-rabbit IgG was the secondary antibody used. No reactivity with any shark protein was noted with anti-histone antibodies indicating (a) lack of reactivity with the heterologous antibody or absence of histone fragment from lysates prepared by sonication. However, when primary antibody to HEWL was used against the same pool, reactivity was seen with a protein band in shark lysate that corresponds to the HEWL reactive control band (intensely stained in Figure 22), strongly suggesting the presence of lysozyme in shark leukocyte lysates. 


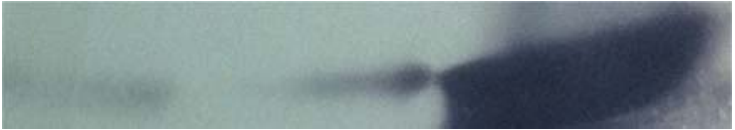

Figure 22 Western blot analysis. Western blot of fractionated lysate sample (Pool I, Protocol IIB) using rabbit antiHEWL antibodies as the primary antibody. Sample was electrophoresed under non-reducing conditions. The blot was developed using goat anti-rabbit HEWL antibody. Lanes 1 and 2 are duplicate samples. 


\section{DISCUSSION}

An integral function of innate immunity in all vertebrates is to protect the host against microbial invasion. Protection is achieved, in part, by the antimicrobial action of a variety of proteins (including enzymes) and peptides associated with body fluids (e.g., tears, saliva, mucus) and specialized cells in peripheral blood and tissues (e.g., cells lining the gut wall). While much is known of the antimicrobial proteins/peptides of mammals, amphibians and bony fish, relatively little information is available on antimicrobials of sharks particularly those associated with peripheral blood leukocytes. The specific aim of this study was to characterize antimicrobial proteins/peptides associated with shark blood leukocytes.

The composition of nurse shark peripheral blood differs significantly from that of teleosts (bony fish) and other vertebrates, particularly, humans. It is important to note that shark plasma contains $0.25 \mathrm{M} \mathrm{NaCl}$ and $0.35 \mathrm{M}$ urea. The high concentration of urea in blood allows these animals to stay in osmotic balance. The high concentration of salt and urea in circulating blood has to be taken into account when developing protocols for processing serum/plasma and/or blood cells. Consequently, methods routinely used in human or mouse research have to be modified by extensive trial and error work on the bench. Staining of peripheral blood smears to obtain differential counts, poses a challenge since most staining reactions depend on acidic and basic reactions of cells. Furthermore, shark erythrocytes are nucleated (unlike that of humans), thus when blood cells undergo lysis (induced or otherwise) considerable quantities of nucleic acid 
released from erythrocytes is present in cell lysates. The presence of nucleic acid can be a hindrance when attempting to isolate proteins/peptides from leukocyte lysates.

Several cell types found in shark peripheral blood are morphologically similar to mammalian cells, although corresponding functional definition for all types remains undetermined. Two types of granulocytic leukocytes are seen, one with deeply staining prominent eosinophilic granules similar in morphology to the mammalian eosinophil, the other with finer neutrophilic granules along with a bi- or tri-lobed nucleus. Ultrastructural studies have shown the shark eosinophil to contain crystalline material within the granules while the shark neutrophil granules are fibrous in nature (Stokes et al. 1971; Hyder et al. 1983; Smith et al. 1989). The proportion of eosinophilic leukocytes in shark blood is considerably higher $(11.5 \%)$ than that seen in human peripheral blood (2.7\%). This, in part can be an indication of a cellular immune response to parasites which are harbored by sharks (Borucinska et al. 1993). Functional studies have shown the shark neutrophil and monocyte-macrophage to be phagocytic, similar to their mammalian counterparts (Hyder et al. 1983; Smith et al. 1989). These two cell types have also been shown to chemotactically (i.e., directional migration) respond to appropriate stimuli (Obenauf et al. 1985; Smith et al. 1989). Some studies have shown in certain shark species, the shark thrombocyte to also be phagocytic (Yokoyama 1960; Fange 1968; Stokes et al. 1971; Ferguson 1976). The spindle shaped thrombocyte is a cell type not found in mammalian blood, and thrombocytes may have an important role in coagulation corresponding to the role of mammalian platelets (Gardner et al. 1969; Stokes et al. 1971; Wardle 1971). In addition to the mononuclear lymphocytes seen in 
peripheral blood, immature, undifferentiated blast-like cells are also occasionally seen. The presence of blast-like cells in peripheral blood is not surprising since sharks with their cartilaginous skeleton do not have bone marrow, the site in mammals where leukocyte maturation and differentiation occurs. In sharks, the site of hematopoiesis (i.e., formation of erythrocytes and leukocytes) is the epigonal organ (a part of its reproductive system), a lymphoid organ, and the spleen (Fange 1977; Fange et al. 1981; Zapata 1981). Since cell lysates prepared from shark peripheral blood leukocytes show significant antibacterial activity, it is reasonable to assume that the factors responsible for this activity are most likely associated with the shark neutrophil and/or eosinophil as well as the monocyte-macrophage, an active phagocytic cell.

A variety of antimicrobial factors, include enzymes such as lysozyme (Petit et al. 1963; Jolles 1967), cathepsin G (Senior et al. 1982; Spitznagel 1990), phospholipase A2 (Dennis 1997), transferrin (Putnam 1975), and antibacterial proteins/peptides (e.g. defensins, magainins, cecropins and cathelicidins) (Boman 1991). As stated above these factors can be found in body fluids (e.g., saliva), mucus produced by the skin (e.g., frogs) and contained within intracellular cytoplasmic granules.

In mammalian granulocytic cells, antibacterial proteins/peptides and enzymes (e.g., lysozyme) are normally found sequestered within intra-cellular granules. My study has shown that cell lysates prepared from nurse shark peripheral blood leukocytes are antibacterial and inhibit the growth of Planococcus citreus, a salt tolerant bacterium. Since shark leukocyte lysates also contained lysozyme activity, it is likely that lysozyme is sequestered within intra-cytoplasmic inclusions (lysosomes) of one or more cell type, 
most probably the phagocytic leukocytes. Lysozyme activity was detected in several lysate preparations and was distinct from the non-lysozyme antibacterial activity, the isolation and characterization of which was the focus of this study. Initial screening of lysates for lysozyme was accomplished using lysoplates (Osserman et al. 1966; Manchenko 1994) and enzyme activity was estimated from the size of the zones of lysis (clearing) of Micrococcus lysodeikticus. Chromatographic fractionation of crude lysates revealed lysozyme activity to be present in early and late fractions recovered from columns suggesting there might by two lysozyme molecules differing perhaps in one or more amino acid residues. Slight differences in primary structure can result in difference in over-all protein charge which would account for the difference in binding strength to the column. A protein corresponding to lysozyme was detected by Western blotting in active fractions. The presence of shark lysozyme in lysate was confirmed by amino acid sequence analysis of a $14 \mathrm{kDa}$ protein separated by SDS-PAGE. The presence of multiple isoforms of lysozyme from the same organism or even the same biological sample has been shown to be the case in the skin mucosa of rainbow trout (Fernandes et al. 2004), the mantle of the pacific oyster (Itoh et al. 2010), and several other invertebrate species (Cancado et al. 2008; Ursic-Bedoya et al. 2008).

A microdilution growth assay was developed in order to achieve greater sensitivity and a method for quantifying the level of antibacterial activity which was expressed as percent inhibition of normal uninhibited bacterial growth. The assay, once standardized, was able to detect levels of antibacterial activity as low as $5 \%$ inhibition in titrated crude lysates. This assay proved to be reliable and reproducible and worked 
over a fairly broad range of $\mathrm{pH}$ and salinity. The density of the target organism did, however, affect the detection sensitivity of the assay. With high bacterial densities the antibacterial activity of lysates was masked since growth inhibition could not be detected spectrophotometrically. A target cell density of $2.5 \times 10^{4} \mathrm{cfu} / \mathrm{ml}$ was determined to be optimal. Planococcus citreus, the target organism routinely used, grows over a relatively wide temperature range, $27^{\circ}$ to $37^{\circ} \mathrm{C}$, with an optimal temperature of $30^{\circ} \mathrm{C}$. The microdilution growth assay is now available and optimized for future studies.

The protein concentration of crude lysates, prepared by sonication, ranged from 2 to $8 \mathrm{mg} / \mathrm{ml}$ depending on the quantity of leukocytes $\left(8 \times 10^{8}-1 \times 10^{9}\right.$ cells $)$ harvested from whole blood. The level of antibacterial activity of crude lysates correlated to the protein concentration of the preparation. Although all lysates prepared showed antibacterial activity, when titrated the level was low for some samples (activity was undetectable following a 2-fold dilution) while in others activity was 16 -fold or higher. Individual variation from animal to animal could account for the variation in activity level. Variation could be as a result of the time or temperature that the blood was collected, or the age or gender of the shark, or even the size of the shark. As blood collection was subject to all these conditions, it is difficult to ascribe a pattern or even control for these variations, given that several different sharks were used in the course of this study.

Initially, crude lysates were used as starting material for chromatographic separation of antibacterial activity. However, the recovery of activity in the active fractions was low. To improve recovery and increase yield crude lysates were subjected to solid phase 
extraction as an initial first step in the isolation protocol. While activity was concentrated by this procedure it was present in a fraction that also contained the bulk of cellular protein and thus did not offer a significant advantage over lyophilization, a less harsh method to obtain concentrated starting material. Ion exchange chromatography of crude lysates concentrated by lyophilization resulted in recovery of significant yield (measured in activity units). Anion exchange chromatography of lysates was effective in separating lysozyme from non-lysozyme antibacterial activity. Initial fractionation of leukocyte lysates yielded several peptides in column fractions which were visualized by SDS-PAGE analysis and identified by N-terminal amino acid sequence analysis to have sequence homology to histone fragments. A variety of histone fragments have been shown to be antibacterial in other vertebrate species (Hiemstra et al. 1993; Robinette et al. 1998; Agerberth et al. 2000; Kawasaki et al. 2003; Patat et al. 2004; Silphaduang et al. 2006).

Several investigators have used more sophisticated methods of chromatography, such as HPLC and reverse phase HPLC, to isolate and purify antimicrobial proteins/peptides (AMPs) from biological samples; however, I found that employing a combination of one or more low pressure chromatography steps is sufficient to isolate the antibacterial activity from the crude cell lysates, and to further separate the active protein(s) from lysozyme, also present in lysates. Although the active protein/peptide(s) were not purified to homogeneity using this simple protocol, it was sufficient to separate the bulk of non-antibacterial material contained in lysates, and to yield a relatively "clean" preparation that contained two to four proteins (seen as distinct 
bands) that could be easily distinguished on coomassie blue stained gels after SDS-PAGE analysis. Furthermore, the antibacterial activity of each protein could be visualized by zones of inhibition on bacterial lawns following transfer of proteins separated by acid urea gel analysis. Consequently, the position of growth inhibition zones on the bacterial lawn could be correlated to individual protein bands present on tandem run gels.

No immunoreactivity was obtained using antibodies to human histones. Therefore, the presence of histones could not be confirmed since no reactivity was noted on the blots. The lack of reaction could be due to (1) the antibodies not recognizing epitopes in nurse shark histone fragments or (2) the concentration of primary and secondary antibodies was not sufficient to get a reaction.

The presence of histone fragments isolated from peripheral blood leukocytes of the nurse shark exhibiting antimicrobial activity has never been shown. These histone fragments, identified by $\mathrm{N}$-terminal sequencing as histones $\mathrm{H} 2 \mathrm{~A}, \mathrm{H} 2 \mathrm{~B}$ and $\mathrm{H} 4$ (identified in a previous study (Hinds et al. 2001)) have been shown in the literature to be antimicrobial in nature (as mentioned above) and isolated from a wide range of organisms, especially aquatic organisms such as teleosts (Park et al. 1998; Birkemo et al. 2003; Fernandes et al. 2004; De Zoysa et al. 2009), bivalves (Li et al. 2007) and shrimp (Patat et al. 2004). Table 7 lists the histone fragments that have been identified by Nterminal amino acid sequence analysis in shark leukocyte lysates and their homology to other known antibacterial peptides identified in other species. 


\section{Table 7 Alignment of Amino Acid Sequence of Shark Histone Fragments}

\begin{tabular}{|c|c|c|c|}
\hline $\begin{array}{l}\text { Histone } \\
\text { Fragment }\end{array}$ & Source & Sequence & Reference \\
\hline H2A & $\begin{array}{l}\text { Nurse Shark H2A-1 } \\
\text { Nurse Shark H2A-2 } \\
\text { Toad stomach tissue } \\
\text { (Buforin) } \\
\text { Catfish (Parasin I) } \\
\text { Pacific white shrimp } \\
\text { hemocyte } \\
\text { Rainbow trout skin } \\
\text { secretions }\end{array}$ & $\begin{array}{l}\text { SRSERAGLQFQK } \\
\text { SIAISRSYRAGLQF } \\
\text { AGRGKQGGKVRAKAKTRSSRAGLQFPVG// } \\
\text { KGRGKQGGKVRAKAKTRSS } \\
\text { SGRGKGGKVKGKSSRSSRAGLQFPVGRI// } \\
\text { AERVGAGAPVYL }\end{array}$ & $\begin{array}{l}\text { Present study } \\
\text { Present study } \\
\text { (Fernandes et al. } \\
\text { 2002) } \\
\text { (Park et al. 1996) } \\
\text { (Park et al. 1998) } \\
\text { (Patat et al. 2004) }\end{array}$ \\
\hline H2B & $\begin{array}{l}\text { Nurse Shark H2B-1 } \\
\text { American oyster } \\
\text { Nurse Shark H2B-2 } \\
\text { Human } \\
\text { Channel catfish } \\
\text { Atlantic cod mucus } \\
\text { Pacific white shrimp } \\
\text { hemocyte }\end{array}$ & $\begin{array}{l}\text { ESYSIYIYK } \\
\text { ESYAIYIYK } \\
\text { KGAK KRSRKEXY } \\
\text { KAQKKDSKKR KRSRKESYSVYVYK// } \\
\text { PDPAKTAPKKGSKKAVTKXA } \\
\text { PEVAKPAAKKGSKKAVSKVA// } \\
\text { AKHAVSEGTKAVT } \\
\end{array}$ & $\begin{array}{l}\text { Present study } \\
\text { (Robinette et al. 1998) } \\
\text { Present study } \\
\text { (Frohm et al. 1996) } \\
\text { (Bergsson et al. 2005) } \\
\text { (Patat et al. 2004) } \\
\text { (Seo et al. 2010) }\end{array}$ \\
\hline H4 & $\begin{array}{l}\text { Nurse Shark H4-1 } \\
\text { Fruit fly* } \\
\text { Pacific white shrimp } \\
\text { hemocyte } \\
\text { Nurse Shark H4- } 2 \\
\text { Fruit fly* }\end{array}$ & $\begin{array}{l}\text { DNIQLITKPAIRQLARR } \\
\text { KVLRDNIQGITKPAIRRLARRGGVK// } \\
\text { RDNIQGITKPAIRRL } \\
\text { RQGRTLYGFX } \\
\text { LKRQGRTLYGFGG }\end{array}$ & $\begin{array}{l}\text { Present study } \\
\text { (Patat et al. 2004) }\end{array}$ \\
\hline
\end{tabular}

Note: Sequences are provided when available with references and sources with asterisk $\left({ }^{*}\right)$ are from deduced amino acid sequences not yet proven to be antibacterial, and obtained through BLAST searches.

Histones have long been known to have antibacterial activity (Hirsch 1958), however, it was not known how they would interact with bacteria in the event of an infection. It was almost 40 years later that Frohm et al (1996) suggested that histones were responsible for wound healing when they isolated histone fragments from human wound and blister fluid. Since then it has become clear that histones or histone fragments are not only present in the nucleus of various organisms, but also in the extra-nuclear region where they can be exposed to intracellular pathogens. The 
discovery of neutrophil extracellular traps (NETs) (Brinkmann et al. 2004) has added to this theory of extra-nuclear histones, even expanding to the possibility that histones work in conjunction with these nets together to trap and kill invading pathogens (Brinkmann et al. 2004; Papayannopoulos et al. 2009). Histones because of their DNA and RNA binding capabilities may work differently in killing bacteria than other traditional antimicrobial peptides. Buforin II, a histone H2A fragment, has been shown to penetrate through the cell membrane and to accumulate inside bacterial cell, leading to the theory that it may inhibit cellular function by binding to nucleic acid (Park et al. 2000). It is therefore not outside the realm of possibilities that the nurse shark H2A fragment which has high homology to buforin, could work in a similar manner. Histone fragments were not identified in shark lysates prepared by sonication indicating that the method of choice for preparing lysates does appear to determine the composition of cellular proteins that will be recovered including those that are antibacterial.

Amino acid sequence analysis also generated some unexpected findings. Two very similar hemoglobin fragments, as well as the protein ubiquitin, were isolated from active chromatographic pools. These two protein fragments are known for having other functions. Hemoglobin is a protein that transports oxygen (Altman et al. 1961) in erythrocytes. Ubiquitin is a protein found everywhere in the cell, thus its name. Ubiquitin's main function is to covalently bind to proteins to act as a tag, and to shuttle the tagged protein to the proteasome for degradation, thereby playing a role in $\mathrm{MHC}$ Class I antigen presentation, as well as in vertebrate immune response via cytotoxic $\mathrm{T}$ cells (Kindt et al. 2007). Hemoglobin from various species, in its intact form, as well as 
fragmented, (Parish et al. 2001; Nakajima et al. 2003) has been shown to be

antibacterial. Ubiquitin, on its own has not been shown to be antibacterial. However, it has been associated, i.e. covalently bound, to histones (e.g. histone H1), which itself was antibacterial (Wang et al. 2002). In addition, ubiquicidin, a protein with high homology to a precursor of ubiquitin, has also been shown to be antibacterial (Hiemstra et al. 1999).

This study has revealed that shark leukocyte lysates contain several antibacterial proteins/peptides, several of which show homology to antibacterial proteins described for species of different phyla, indicating conservation of form and function through evolution. This premise is particularly true for a protein such as lysozyme. Sequence analysis also identified proteins with no known homology and which could very well be unique to the shark. The elucidation of the mechanism of antibacterial activity of lysate proteins/peptides was beyond the scope of this study, and remains a future goal. It is clear from the data presented that several antibacterial proteins/peptides associated with non-oxidative antibacterial activity of mammalian leukocytes are also found in the nurse shark, a primitive vertebrate. With this theory in mind, it could be said that shark antibacterial proteins/peptides, play a significant role in the shark's resilience to infection and disease and its longevity. 


\section{BIBLIOGRAPHY}

Agerberth, B., Charo, J., Werr, J., Olsson, B., Idali, F., Lindbom, L., Kiessling, R., Jornvall, H., Wigzell, H. and Gudmundsson, G. H. (2000). "The human antimicrobial and chemotactic peptides LL-37 and alpha-defensins are expressed by specific lymphocyte and monocyte populations." Blood 96(9): 3086-93.

Altman, P. L. and Katz, D. D. (1961). Blood and other body fluids. Washington,, Federation of American Societies for Experimental Biology.

Alvarez, R. J. and Koburger, J. A. (1981). "Effect of Planococcus citreus [spoilage bacteria] on selected quality indices of Penaeus shrimp." Journal of Food Protection (USA) 44(5): 359-363, 368.

Andersson, M., Gunne, H., Agerberth, B., Boman, A., Bergman, T., Sillard, R., Jornvall, H., Mutt, V., Olsson, B., Wigzell, H. and et al. (1995). "NK-lysin, a novel effector peptide of cytotoxic $T$ and NK cells. Structure and CDNA cloning of the porcine form, induction by interleukin 2, antibacterial and antitumour activity." EMBO J 14(8): 1615-25.

Augusto LA, D. P., Synguelakis M, Nicaise M, Marechal P and Chaby R. (2003). "Histones: A novel class of lipopolysaccharide-binding molecules." Biochemistry 42: 3929-3938.

Ayabe, T., Ashida, T., Kohgo, Y. and Kono, T. (2004). "The role of Paneth cells and their antimicrobial peptides in innate host defense." Trends Microbiol 12(8): 394-8.

Ayabe, T., Satchell, D. P., Wilson, C. L., Parks, W. C., Selsted, M. E. and Ouellette, A. J. (2000). "Secretion of microbicidal alpha-defensins by intestinal Paneth cells in response to bacteria." Nat Immunol 1(2): 113-8.

Aybar, L., Shin, D. H. and Smith, S. L. (2009). "Molecular characterization of the alpha subunit of complement component C8 (GcC8alpha) in the nurse shark (Ginglymostoma cirratum)." Fish Shellfish Immunol 27(3): 397-406.

Bals, R. (2000). "Epithelial antimicrobial peptides in host defense against infection." Respir Res 1(3): 141-50. 
Bals, R. and Wilson, J. M. (2003). "Cathelicidins--a family of multifunctional antimicrobial peptides." Cell Mol Life Sci 60(4): 711-20.

Barra, D., Simmaco, M. and Boman, H. G. (1998). "Gene-encoded peptide antibiotics and innate immunity. Do 'animalcules' have defence budgets?" FEBS Lett 430(1-2): 130-4.

Bechinger, B., Aisenbrey, C. and Bertani, P. (2004). "The alignment, structure and dynamics of membrane-associated polypeptides by solid-state NMR spectroscopy." Biochim Biophys Acta 1666(1-2): 190-204.

Befus, A. D., Mowat, C., Gilchrist, M., Hu, J., Solomon, S. and Bateman, A. (1999). "Neutrophil defensins induce histamine secretion from mast cells: mechanisms of action." J Immunol 163(2): 947-53.

Bellamy, W., Wakabayashi, H., Takase, M., Kawase, K., Shimamura, S. and Tomita, M. (1993). "Killing of Candida albicans by lactoferricin B, a potent antimicrobial peptide derived from the N-terminal region of bovine lactoferrin." Med Microbiol Immunol 182(2): 97105.

Ben-Efraim, I. and Shai, Y. (1997). "The structure and organization of synthetic putative membranous segments of ROMK1 channel in phospholipid membranes." Biophys J 72(1): 85-96.

Bergsson, G., Agerberth, B., Jornvall, H. and Gudmundsson, G. H. (2005). "Isolation and identification of antimicrobial components from the epidermal mucus of Atlantic cod (Gadus morhua)." FEBS J 272(19): 4960-9.

Bevins, C. L., Martin-Porter, E. and Ganz, T. (1999). "Defensins and innate host defence of the gastrointestinal tract." Gut 45(6): 911-5.

Birkemo, G. A., Luders, T., Andersen, O., Nes, I. F. and Nissen-Meyer, J. (2003). "Hipposin, a histone-derived antimicrobial peptide in Atlantic halibut (Hippoglossus hippoglossus L.)." Biochim Biophys Acta 1646(1-2): 207-15.

Bolton, S. J. and Perry, V. H. (1997). "Histone H1; a neuronal protein that binds bacterial lipopolysaccharide." J Neurocytol 26(12): 823-31. 
Boman, H. G. (1991). "Antibacterial peptides: key components needed in immunity." Cell 65(2): 205-7.

Boman, H. G. (1995). "Peptide antibiotics and their role in innate immunity." Annu Rev Immunol 13: 61-92.

Boman, H. G. (1998). "Gene-encoded peptide antibiotics and the concept of innate immunity: an update review." Scand J Immunol 48(1): 15-25.

Boman, H. G. (2000). "Innate immunity and the normal microflora." Immunol Rev 173: 5-16.

Boman, H. G. (2003). "Antibacterial peptides: basic facts and emerging concepts." J Intern Med 254(3): 197-215.

Boman, H. G., Faye, I., von Hofsten, P., Kockum, K., Lee, J. Y., Xanthopoulos, K. G., Bennich, H., Engstrom, A., Merrifield, R. B. and Andreu, D. (1985). "On the primary structures of lysozyme, cecropins and attacins from Hyalophora cecropia." Dev Comp Immunol 9(3): 551-8.

Borucinska, J. and Caira, J. N. (1993). "A comparison of mode of attachment and histopathogenicity of four tapeworm species representing two orders infecting the spiral intestine of the nurse shark, Ginglymostoma cirratum." J Parasitol 79(2): 238-46.

Bowdish, D. M., Davidson, D. J., Lau, Y. E., Lee, K., Scott, M. G. and Hancock, R. E. (2005). "Impact of LL-37 on anti-infective immunity." J Leukoc Biol 77(4): 451-9.

Brahmachary, M., Krishnan, S. P., Koh, J. L., Khan, A. M., Seah, S. H., Tan, T. W., Brusic, V. and Bajic, V. B. (2004). "ANTIMIC: a database of antimicrobial sequences." Nucleic Acids Res 32(Database issue): D586-9.

Brinkmann, V., Reichard, U., Goosmann, C., Fauler, B., Uhlemann, Y., Weiss, D. S., Weinrauch, Y. and Zychlinsky, A. (2004). "Neutrophil extracellular traps kill bacteria." Science 303(5663): 1532-5. 
Brix, K., Summa, W., Lottspeich, F. and Herzog, V. (1998). "Extracellularly occurring histone H1 mediates the binding of thyroglobulin to the cell surface of mouse macrophages." $\mathrm{J}$ Clin Invest 102(2): 283-93.

Brogden, K. A. (2005). "Antimicrobial peptides: pore formers or metabolic inhibitors in bacteria?" Nat Rev Microbiol 3(3): 238-50.

Brogden, K. A., Heidari, M., Sacco, R. E., Palmquist, D., Guthmiller, J. M., Johnson, G. K., Jia, H. P., Tack, B. F. and McCray, P. B. (2003). "Defensin-induced adaptive immunity in mice and its potential in preventing periodontal disease." Oral Microbiol Immunol 18(2): 95-9.

Brown, P. (2001). "Cinderella goes to the ball." Nature 410(6832): 1018-20.

Bucki, R., Leszczynska, K., Namiot, A. and Sokolowski, W. (2010). "Cathelicidin LL-37: a multitask antimicrobial peptide." Arch Immunol Ther Exp (Warsz) 58(1): 15-25.

Bullen, J. J. and Armstrong, J. A. (1979). "The role of lactoferrin in the bactericidal function of polymorphonuclear leucocytes." Immunology 36(4): 781-91.

Burnet, F. M. (1957). "A modification of Jerne's theory of antibody production using the concept of clonal selection." Australian Journal of Science 20: 67-69.

Campopiano, D. J., Clarke, D. J., Polfer, N. C., Barran, P. E., Langley, R. J., Govan, J. R., Maxwell, A. and Dorin, J. R. (2004). "Structure-activity relationships in defensin dimers: a novel link between beta-defensin tertiary structure and antimicrobial activity." J Biol Chem 279(47): 48671-9.

Cancado, F. C., Chimoy Effio, P., Terra, W. R. and Marana, S. R. (2008). "Cloning, purification and comparative characterization of two digestive lysozymes from Musca domestica larvae." Braz J Med Biol Res 41(11): 969-77.

Castagnaro, A., Marana, C., Carbonero, P. and Garcia-Olmedo, F. (1992). "Extreme divergence of a novel wheat thionin generated by a mutational burst specifically affecting the mature protein domain of the precursor." J Mol Biol 224(4): 1003-9. 
Casteels, P., Ampe, C., Jacobs, F., Vaeck, M. and Tempst, P. (1989). "Apidaecins: antibacterial peptides from honeybees." EMBO J 8(8): 2387-91.

Chaly, Y. V., Paleolog, E. M., Kolesnikova, T. S., Tikhonov, II, Petratchenko, E. V. and Voitenok, N. N. (2000). "Neutrophil alpha-defensin human neutrophil peptide modulates cytokine production in human monocytes and adhesion molecule expression in endothelial cells." Eur Cytokine Netw 11(2): 257-66.

Chan, D. I., Prenner, E. J. and Vogel, H. J. (2006). "Tryptophan- and arginine-rich antimicrobial peptides: structures and mechanisms of action." Biochim Biophys Acta 1758(9): 1184202.

Chang, C. H. and Luse, D. S. (1997). "The H3/H4 tetramer blocks transcript elongation by RNA polymerase II in vitro." J Biol Chem 272(37): 23427-34.

Cho, J. H., Park, I. Y., Kim, H. S., Lee, W. T., Kim, M. S. and Kim, S. C. (2002). "Cathepsin D produces antimicrobial peptide parasin I from histone H2A in the skin mucosa of fish." FASEB J 16(3): 429-31.

Cho, S. H., Lee, B. D., An, H. and Eun, J. B. (2005). "Kenojeinin I, antimicrobial peptide isolated from the skin of the fermented skate, Raja kenojei." Peptides 26(4): 581-7.

Christensen, B., Fink, J., Merrifield, R. B. and Mauzerall, D. (1988). "Channel-forming properties of cecropins and related model compounds incorporated into planar lipid membranes." Proc Natl Acad Sci U S A 85(14): 5072-6.

Clark, E. (1963). The maintenance of sharks in captivity, with a report in their instrumental conditioning. Sharks and survival P. W. Gilbert. Boston, D.C. Heath: 115-149.

Clem, L. W. and Leslie, G. A. (1982). "Phylogeny of immunoglobulin structure and function XV. Idiotypic analysis of shark antibodies." Dev Comp Immunol 6(3): 463-72.

Cole, A. M., Weis, P. and Diamond, G. (1997). "Isolation and characterization of pleurocidin, an antimicrobial peptide in the skin secretions of winter flounder." J Biol Chem 272(18): 12008-13. 
Dale, B. A., Tao, R., Kimball, J. R. and Jurevic, R. J. (2006). "Oral antimicrobial peptides and biological control of caries." BMC Oral Health 6 Suppl 1: S13.

Davies, D. H., Lawson, R., Burch, S. J. and Hanson, J. E. (1987). "Evolutionary relationships of a "primitive" shark (Heterodontus) assessed by micro-complement fixation of serum transferrin." J Mol Evol 25(1): 74-80.

De Zoysa, M., Nikapitiya, C., Whang, I., Lee, J. S. and Lee, J. (2009). "Abhisin: a potential antimicrobial peptide derived from histone H2A of disk abalone (Haliotis discus discus)." Fish Shellfish Immunol 27(5): 639-46.

Dennis, E. A. (1997). "The growing phospholipase A2 superfamily of signal transduction enzymes." Trends Biochem Sci 22(1): 1-2.

Destoumieux, D., Bulet, P., Loew, D., Van Dorsselaer, A., Rodriguez, J. and Bachere, E. (1997). "Penaeidins, a new family of antimicrobial peptides isolated from the shrimp Penaeus vannamei (Decapoda)." J Biol Chem 272(45): 28398-406.

Diamond, G., Beckloff, N., Weinberg, A. and Kisich, K. O. (2009). "The roles of antimicrobial peptides in innate host defense." Curr Pharm Des 15(21): 2377-92.

Diamond, G., Zasloff, M., Eck, H., Brasseur, M., Maloy, W. L. and Bevins, C. L. (1991). "Tracheal antimicrobial peptide, a cysteine-rich peptide from mammalian tracheal mucosa: peptide isolation and cloning of a cDNA." Proc Natl Acad Sci U S A 88(9): 3952-6.

Dodds, A. W., Smith, S. L., Levine, R. P. and Willis, A. C. (1998). "Isolation and initial characterisation of complement components $\mathrm{C} 3$ and $\mathrm{C} 4$ of the nurse shark and the channel catfish." Dev Comp Immunol 22(2): 207-16.

Dooley, H. and Flajnik, M. F. (2005). "Shark immunity bites back: affinity maturation and memory response in the nurse shark, Ginglymostoma cirratum." Eur J Immunol 35(3): 936-45.

Ellison, R. T., 3rd and Giehl, T. J. (1991). "Killing of gram-negative bacteria by lactoferrin and lysozyme." J Clin Invest 88(4): 1080-91. 
Elsbach, P. and Weiss, J. (1993). "The bactericidal/permeability-increasing protein (BPI), a potent element in host-defense against gram-negative bacteria and lipopolysaccharide." Immunobiology 187(3-5): 417-29.

Ewen, M. E. (2000). "Where the cell cycle and histones meet." Genes Dev 14(18): 2265-70.

Fang, F. (1997). "NO contest: nitric oxide plays complex roles in infection." ASM News 63: 66873.

Fange, R. (1968). "White blood cells and lymphomyeloid tissues in fish." Bull Off Int Epizoot 69(9): 1357-63.

Fange, R. (1977). "Size Relations of Lymphomyeloid Organs in Some Cartilaginous Fish." Acta Zoologica 58(3): 125-128.

Fange, R. and Mattison, A. (1981). "The lymphomyeloid (hemopoietic) system of the atlantic nurse shark, ginglymostoma cirratum." The biological bulletin 160: 240-249.

Fange, R., Lundblad, G and Lind, J. (1976). "Lysozyme and chitinase in blood and lymphomyeloid tissues of marine fish." Marine Biology 36: 277-282.

Feizi, T. (2000). "Carbohydrate-mediated recognition systems in innate immunity." Immunol Rev 173: 79-88.

Fennell, J. F., Shipman, W. H. and Cole, L. J. (1968). "Antibacterial action of melittin, a polypeptide from bee venom." Proc Soc Exp Biol Med 127(3): 707-10.

Ferguson, H. W. (1976). "The ultrastructure of plaice leukocytes." J Fish Biol 8: 139-142.

Fernandes, J. M., Kemp, G. D., Molle, M. G. and Smith, V. J. (2002). "Anti-microbial properties of histone H2A from skin secretions of rainbow trout, Oncorhynchus mykiss." Biochem J 368(Pt 2): 611-20. 
Fernandes, J. M., Kemp, G. D. and Smith, V. J. (2004). "Two novel muramidases from skin mucosa of rainbow trout (Oncorhynchus mykiss)." Comp Biochem Physiol B Biochem Mol Biol 138(1): 53-64.

Fernandes, J. M., Molle, G., Kemp, G. D. and Smith, V. J. (2004). "Isolation and characterisation of oncorhyncin II, a histone H1-derived antimicrobial peptide from skin secretions of rainbow trout, Oncorhynchus mykiss." Dev Comp Immunol 28(2): 127-38.

Fernandez de Caleya, R., Gonzalez-Pascual, B., Garcia-Olmedo, F. and Carbonero, P. (1972). "Susceptibility of phytopathogenic bacteria to wheat purothionins in vitro." Appl Microbiol 23(5): 998-1000.

Fjell, C. D., Hancock, R. E. and Cherkasov, A. (2007). "AMPer: a database and an automated discovery tool for antimicrobial peptides." Bioinformatics 23(9): 1148-55.

Flajnik, M. F. (1994). "Primitive vertebrate immunity: what is the evolutionary derivative of molecules that define the adaptive immune system?" Ciba Found Symp 186: 224-32; discussion 233-6.

Flajnik, M. F. and Dooley, H. (2009). "The generation and selection of single-domain, $v$ region libraries from nurse sharks." Methods Mol Biol 562: 71-82.

Fleischmann, J., Selsted, M. E. and Lehrer, R. I. (1985). "Opsonic activity of MCP-1 and MCP-2, cationic peptides from rabbit alveolar macrophages." Diagn Microbiol Infect Dis 3(3): 233-42.

Frank, R. W., Gennaro, R., Schneider, K., Przybylski, M. and Romeo, D. (1990). "Amino acid sequences of two proline-rich bactenecins. Antimicrobial peptides of bovine neutrophils." J Biol Chem 265(31): 18871-4.

Frohm, M., Gunne, H., Bergman, A. C., Agerberth, B., Bergman, T., Boman, A., Liden, S., Jornvall, H. and Boman, H. G. (1996). "Biochemical and antibacterial analysis of human wound and blister fluid." Eur J Biochem 237(1): 86-92.

Funderburg, N., Lederman, M. M., Feng, Z., Drage, M. G., Jadlowsky, J., Harding, C. V., Weinberg, A. and Sieg, S. F. (2007). "Human -defensin-3 activates professional antigen-presenting cells via Toll-like receptors 1 and 2." Proc Natl Acad Sci U S A 104(47): 18631-5. 
Ganz, T. (2006). "Hepcidin and its role in regulating systemic iron metabolism." Hematology Am Soc Hematol Educ Program: 29-35, 507.

Ganz, T. and Lehrer, R. I. (1998). "Antimicrobial peptides of vertebrates." Curr Opin Immunol 10(1): 41-4.

Ganz, T. and Weiss, J. (1997). "Antimicrobial peptides of phagocytes and epithelia." Semin Hematol 34(4): 343-54.

Garcia-Olmedo, F., Molina, A., Alamillo, J. M. and Rodriguez-Palenzuela, P. (1998). "Plant defense peptides." Biopolymers 47(6): 479-91.

Gardner, G. R. and Yevich, P. P. (1969). "Studies on the blood morphology of three estuarine cyprinodontiform fishes." J Fish Res Bd Can 2: 433-447.

Garzino-Demo, A. (2007). "Chemokines and defensins as HIV suppressive factors: an evolving story." Curr Pharm Des 13(2): 163-72.

Gennaro, R., Zanetti, M., Benincasa, M., Podda, E. and Miani, M. (2002). "Pro-rich antimicrobial peptides from animals: structure, biological functions and mechanism of action." Curr Pharm Des 8(9): 763-78.

Girardin, S. E., Sansonetti, P. J. and Philpott, D. J. (2002). "Intracellular vs extracellular recognition of pathogens--common concepts in mammals and flies." Trends Microbiol 10(4): 193-9.

Gordon, L. I., Douglas, S. D., Kay, N. E., Yamada, O., Osserman, E. F. and Jacob, H. S. (1979). "Modulation of neutrophil function by lysozyme. Potential negative feedback system of inflammation." J Clin Invest 64(1): 226-32.

Graham, M., Shin, D. H. and Smith, S. L. (2009). "Molecular and expression analysis of complement component $\mathrm{C} 5$ in the nurse shark (Ginglymostoma cirratum) and its predicted functional role." Fish Shellfish Immunol 27(1): 40-9. 
Greenberg, A. S., Avila, D., Hughes, M., Hughes, A., McKinney, E. C. and Flajnik, M. F. (1995). "A new antigen receptor gene family that undergoes rearrangement and extensive somatic diversification in sharks." Nature 374(6518): 168-73.

Haines, A. N., Flajnik, M. F., Rumfelt, L. L. and Wourms, J. P. (2005). "Immunoglobulins in the eggs of the nurse shark, Ginglymostoma cirratum." Dev Comp Immunol 29(5): 417-30.

Hancock, I. C. (1997). "Bacterial cell surface carbohydrates: structure and assembly." Biochem Soc Trans 25(1): 183-7.

Hancock, L. E. and Gilmore, M. S. (1997). "Identification of a highly conserved lipopolysaccharide (LPS) modification operon in Enterococcus faecalis." Adv Exp Med Biol 418: 1049-50.

Hancock, R. E. and Lehrer, R. (1998). "Cationic peptides: a new source of antibiotics." Trends Biotechnol 16(2): 82-8.

Harrison, S. J., McManus, A. M., Marcus, J. P., Goulter, K. C., Green, J. L., Nielsen, K. J., Craik, D. J., Maclean, D. J. and Manners, J. M. (1999). "Purification and characterization of a plant antimicrobial peptide expressed in Escherichia coli." Protein Expr Purif 15(2): 171-7.

Harwig, S. S., Swiderek, K. M., Kokryakov, V. N., Tan, L., Lee, T. D., Panyutich, E. A., Aleshina, G. M., Shamova, O. V. and Lehrer, R. I. (1994). "Gallinacins: cysteine-rich antimicrobial peptides of chicken leukocytes." FEBS Lett 342(3): 281-5.

Hedayati, A. (1992). Studies of lysozyme-like activity in nurse shark serum. Medical Laboratory Science. Miami, Florida International University. M.S.

Herbert, W. J. and Wilkinson, P. C. (1977). A dictionary of immunology. Oxford, Philadelphia, Blackwell Scientific Publications.

Hiemstra, P. S., Eisenhauer, P. B., Harwig, S. S., van den Barselaar, M. T., van Furth, R. and Lehrer, R. I. (1993). "Antimicrobial proteins of murine macrophages." Infect Immun 61(7): 3038-46. 
Hiemstra, P. S., van den Barselaar, M. T., Roest, M., Nibbering, P. H. and van Furth, R. (1999). "Ubiquicidin, a novel murine microbicidal protein present in the cytosolic fraction of macrophages." J Leukoc Biol 66(3): 423-8.

Hill, C. P., Yee, J., Selsted, M. E. and Eisenberg, D. (1991). "Crystal structure of defensin HNP-3, an amphiphilic dimer: mechanisms of membrane permeabilization." Science 251(5000): 1481-5.

Hinds, N., Smith, S. L. and Smith, V. J. (2001). "Antibacterial activity of shark leukocyte lysates." FASEB J 15(Part 1): A692.

Hirsch, J. G. (1958). "Bactericidal action of histone." J Exp Med 108(6): 925-44.

Howell, S. J., Wilk, D., Yadav, S. P. and Bevins, C. L. (2003). "Antimicrobial polypeptides of the human colonic epithelium." Peptides 24(11): 1763-70.

Huang, H. J., Ross, C. R. and Blecha, F. (1997). "Chemoattractant properties of PR-39, a neutrophil antibacterial peptide." J Leukoc Biol 61(5): 624-9.

Hyder, S. L., Cayer, M. L. and Pettey, C. L. (1983). "Cell types in peripheral blood of the nurse shark: an approach to structure and function." Tissue Cell 15(3): 437-55.

Ichinose, M., Asai, M., Imai, K. and Sawada, M. (1996). "Enhancement of phagocytosis by corticostatin I (CSI) in cultured mouse peritoneal macrophages." Immunopharmacology 35(2): 103-9.

Imoto, T., Johnson, L.N., North, A.C.T., Phillips, D.C. and Rupley, J.A. (1972). Vertebrate lysozyme. The enzymes. B. P.D. NY, Academic Press. 1: 665-836.

Ingram, G. A. (1980). "Substances involved in natural resistance of fish to infection-A review." J Fish Biol 16: 23-60.

Isenberg, I. (1979). "Histones." Annu Rev Biochem 48: 159-91. 
Itoh, N., Okada, Y., Takahashi, K. G. and Osada, M. (2010). "Presence and characterization of multiple mantle lysozymes in the Pacific oyster, Crassostrea gigas." Fish Shellfish Immunol 29(1): 126-35.

Jacobsen, F., Baraniskin, A., Mertens, J., Mittler, D., Mohammadi-Tabrisi, A., Schubert, S., Soltau, M., Lehnhardt, M., Behnke, B., Gatermann, S., Steinau, H. U. and Steinstraesser, L. (2005). "Activity of histone H1.2 in infected burn wounds." J Antimicrob Chemother 55(5): 735-41.

Jolles, J. and Jolles, P. (1966). "Isolation and purification of the biologically active des-lysylvalyl phenylalanine-lysozyme." Biochem Biophys Res Commun 22(1): 22-5.

Jolles, J. and Jolles, P. (1975). "The losozyme from Asterias rubens." Eur J Biochem 54(1): 19-23.

Jolles, P. (1967). "Relationship between chemical structure and biological activity of hen eggwhite lysozyme and lysozymes of different species." Proc R Soc Lond B Biol Sci 167(9): 350-64.

Jolles, P. (1969). "Lysozymes: a chapter of molecular biology." Angewandte chemie-international edition 8(4): 227-294.

Jolles, P. (1996). "From the discovery of lysozyme to the characterization of several lysozyme families." EXS 75: 3-5.

Jolles, P. and Jolles, J. (1984). "What's new in lysozyme research? Always a model system, today as yesterday." Mol Cell Biochem 63(2): 165-89.

Kawasaki, H., Isaacson, T., Iwamuro, S. and Conlon, J. M. (2003). "A protein with antimicrobial activity in the skin of Schlegel's green tree frog Rhacophorus schlegelii (Rhacophoridae) identified as histone H2B." Biochem Biophys Res Commun 312(4): 1082-6.

Kawasaki, H. and Iwamuro, S. (2008). "Potential roles of histones in host defense as antimicrobial agents." Infect Disord Drug Targets 8(3): 195-205. 
Kelly, P., Bajaj-Elliott, M., Katubulushi, M., Zulu, I., Poulsom, R., Feldman, R. A., Bevins, C. L. and Dhaliwal, W. (2006). "Reduced gene expression of intestinal alpha-defensins predicts diarrhea in a cohort of African adults." J Infect Dis 193(10): 1464-70.

Kim, H. S., Cho, J. H., Park, H. W., Yoon, H., Kim, M. S. and Kim, S. C. (2002). "Endotoxinneutralizing antimicrobial proteins of the human placenta." J Immunol 168(5): 2356-64.

Kim, H. S., Yoon, H., Minn, I., Park, C. B., Lee, W. T., Zasloff, M. and Kim, S. C. (2000). "Pepsinmediated processing of the cytoplasmic histone $\mathrm{H} 2 \mathrm{~A}$ to strong antimicrobial peptide buforin I." J Immunol 165(6): 3268-74.

Kim, J. Y., Park, S. C., Hwang, I., Cheong, H., Nah, J. W., Hahm, K. S. and Park, Y. (2009). "Protease inhibitors from plants with antimicrobial activity." Int J Mol Sci 10(6): 2860-72.

Kindt, T. J., Goldsby, R. A., Osborne, B. A. and Kuby, J. (2007). Kuby immunology. New York, W.H. Freeman.

Klein, J. a. H. V., Ed. ( 1997). Immunology. Defense reactions mediated by phagocytes. NY, John Wiley and Sons Ltd.

Kudo, T., Kigoshi, H., Hagiwara, T., Takino, T., Yamazaki, M. and Yui, S. (2009). "Cathepsin G, a neutrophil protease, induces compact cell-cell adhesion in MCF-7 human breast cancer cells." Mediators Inflamm 2009: 850940.

Ladokhin, A. S., Selsted, M. E. and White, S. H. (1997). "Sizing membrane pores in lipid vesicles by leakage of co-encapsulated markers: pore formation by melittin." Biophys J 72(4): $1762-6$.

Laemmli, U. K. (1970). "Cleavage of structural proteins during the assembly of the head of bacteriophage T4." Nature 227(5259): 680-5.

Lee, D. Y., Huang, C. M., Nakatsuji, T., Thiboutot, D., Kang, S. A., Monestier, M. and Gallo, R. L. (2009). "Histone $\mathrm{H} 4$ is a major component of the antimicrobial action of human sebocytes." J Invest Dermatol 129(10): 2489-96. 
Lee, I. H., Cho, Y. and Lehrer, R. I. (1997). "Styelins, broad-spectrum antimicrobial peptides from the solitary tunicate, Styela clava." Comp Biochem Physiol B Biochem Mol Biol 118(3): 515-21.

Lee, M. T., Chen, F. Y. and Huang, H. W. (2004). "Energetics of pore formation induced by membrane active peptides." Biochemistry 43(12): 3590-9.

Lehrer, R. I., Barton, A., Daher, K. A., Harwig, S. S., Ganz, T. and Selsted, M. E. (1989). "Interaction of human defensins with Escherichia coli. Mechanism of bactericidal activity." J Clin Invest 84(2): 553-61.

Lehrer, R. I. and Ganz, T. (1992). "Defensins: endogenous antibiotic peptides from human leukocytes." Ciba Found Symp 171: 276-90; discussion 290-3.

Lehrer, R. I., Rosenman, M., Harwig, S. S., Jackson, R. and Eisenhauer, P. (1991). "Ultrasensitive assays for endogenous antimicrobial polypeptides." J Immunol Methods 137(2): 167-73.

Li, C., Song, L., Zhao, J., Zhu, L., Zou, H., Zhang, H., Wang, H. and Cai, Z. (2007). "Preliminary study on a potential antibacterial peptide derived from histone $\mathrm{H} 2 \mathrm{~A}$ in hemocytes of scallop Chlamys farreri." Fish Shellfish Immunol 22(6): 663-72.

Li, G. H., Mine, Y., Hincke, M. T. and Nys, Y. (2007). "Isolation and characterization of antimicrobial proteins and peptide from chicken liver." J Pept Sci 13(6): 368-78.

Li, J., Post, M., Volk, R., Gao, Y., Li, M., Metais, C., Sato, K., Tsai, J., Aird, W., Rosenberg, R. D., Hampton, T. G., Sellke, F., Carmeliet, P. and Simons, M. (2000). "PR39, a peptide regulator of angiogenesis." Nat Med 6(1): 49-55.

Lillard, J. W., Jr., Boyaka, P. N., Chertov, O., Oppenheim, J. J. and McGhee, J. R. (1999). "Mechanisms for induction of acquired host immunity by neutrophil peptide defensins." Proc Natl Acad Sci U S A 96(2): 651-6.

Makemson, J. C., Fulayfil, N. R. and Van Ert, L. (1998). "Differentiation of marine luminous bacteria using commercial identification plates." J Biolumin Chemilumin 13(3): 147-56. 
Mallow, E. B., Harris, A., Salzman, N., Russell, J. P., DeBerardinis, R. J., Ruchelli, E. and Bevins, C. L. (1996). "Human enteric defensins. Gene structure and developmental expression." J Biol Chem 271(8): 4038-45.

Manchenko, G. P. (1994). Methods of detection of specific enzymes. Handbook of Detection of Enzymes on Electrophoretic Gels. G. P. Manchenko. Raton, CRC Press: 223.

Masson, P. L., Heremans, J. F., Prignot, J. J. and Wauters, G. (1966). "Immunohistochemical localization and bacteriostatic properties of an iron-binding protein from bronchial mucus." Thorax 21(6): 538-44.

Merly, L., Simjee, S. and Smith, S. L. (2007). "Induction of inflammatory cytokines by cartilage extracts." Int Immunopharmacol 7(3): 383-91.

Moore, A. J., Beazley, W. D., Bibby, M. C. and Devine, D. A. (1996). "Antimicrobial activity of cecropins." J. Antimicrob. Chemother. 37(6): 1077-1089.

Moore, K. S., Wehrli, S., Roder, H., Rogers, M., Forrest, J. N., Jr., McCrimmon, D. and Zasloff, M. (1993). "Squalamine: an aminosterol antibiotic from the shark." Proc Natl Acad Sci U S A 90(4): 1354-8.

Munoz, M., Vandenbulcke, F., Saulnier, D. and Bachere, E. (2002). "Expression and distribution of penaeidin antimicrobial peptides are regulated by haemocyte reactions in microbial challenged shrimp." Eur J Biochem 269(11): 2678-89.

Nagaoka, I., Hirota, S., Niyonsaba, F., Hirata, M., Adachi, Y., Tamura, H. and Heumann, D. (2001). "Cathelicidin family of antibacterial peptides CAP18 and CAP11 inhibit the expression of TNF-alpha by blocking the binding of LPS to CD14(+) cells." J Immunol 167(6): 3329-38.

Nagaoka, I., Hirota, S., Niyonsaba, F., Hirata, M., Adachi, Y., Tamura, H., Tanaka, S. and Heumann, D. (2002). "Augmentation of the lipopolysaccharide-neutralizing activities of human cathelicidin CAP18/LL-37-derived antimicrobial peptides by replacement with hydrophobic and cationic amino acid residues." Clin Diagn Lab Immunol 9(5): 972-82.

Nakajima, Y., Ogihara, K., Taylor, D. and Yamakawa, M. (2003). "Antibacterial hemoglobin fragments from the midgut of the soft tick, Ornithodoros moubata (Acari: Argasidae)." J Med Entomol 40(1): 78-81. 
Niyonsaba, F., Someya, A., Hirata, M., Ogawa, H. and Nagaoka, I. (2001). "Evaluation of the effects of peptide antibiotics human beta-defensins-1/-2 and LL-37 on histamine release and prostaglandin D(2) production from mast cells." Eur J Immunol 31(4): 1066-75.

Noga, E. J., Fan, Z. and Silphaduang, U. (2001). "Histone-like proteins from fish are lethal to the parasitic dinoflagellate Amyloodinium ocellatum." Parasitology 123(Pt 1): 57-65.

Noga, E. J. and Silphaduang, U. (2003). "Piscidins: a novel family of peptide antibiotics from fish." Drug News Perspect 16(2): 87-92.

Nomura, I., Goleva, E., Howell, M. D., Hamid, Q. A., Ong, P. Y., Hall, C. F., Darst, M. A., Gao, B., Boguniewicz, M., Travers, J. B. and Leung, D. Y. (2003). "Cytokine milieu of atopic dermatitis, as compared to psoriasis, skin prevents induction of innate immune response genes." J Immunol 171(6): 3262-9.

Obenauf, S. D. and Smith, S. H. (1985). "Chemotaxis of nurse shark leukocytes." Dev Comp Immunol 9(2): 221-30.

Odeberg, H. and Olsson, I. (1975). "Antibacterial activity of cationic proteins from human granulocytes." J Clin Invest 56(5): 1118-24.

Ogundele, M. O. (1998). "A novel anti-inflammatory activity of lysozyme: modulation of serum complement activation." Mediators Inflamm 7(5): 363-5.

Ohta, Y., McKinney, E. C., Criscitiello, M. F. and Flajnik, M. F. (2002). "Proteasome, transporter associated with antigen processing, and class I genes in the nurse shark Ginglymostoma cirratum: evidence for a stable class I region and MHC haplotype lineages." J Immunol 168(2): 771-81.

Ong, P. Y., Ohtake, T., Brandt, C., Strickland, I., Boguniewicz, M., Ganz, T., Gallo, R. L. and Leung, D. Y. (2002). "Endogenous antimicrobial peptides and skin infections in atopic dermatitis." N Engl J Med 347(15): 1151-60.

Oren, Z. and Shai, Y. (1998). "Mode of action of linear amphipathic alpha-helical antimicrobial peptides." Biopolymers 47(6): 451-63. 
Osserman, E. F. (1976). "Postulated relationships between lysozyme and immunoglobulins as mediators of macrophage and plasma cell functions." Adv Pathobiol 4: 98-105.

Osserman, E. F., Klockars, M., Halper, J. and Fischel, R. E. (1973). "Effects of lysozyme on normal and transformed mammalian cells." Nature 243(5406): 331-5.

Osserman, E. F. and Lawlor, D. P. (1966). "Serum and urinary lysozyme (muramidase) in monocytic and monomyelocytic leukemia." J Exp Med 124(5): 921-52.

Ouellette, A. J. and Selsted, M. E. (1996). "Paneth cell defensins: endogenous peptide components of intestinal host defense." FASEB J 10(11): 1280-9.

Palffy, R., Gardlik, R., Behuliak, M., Kadasi, L., Turna, J. and Celec, P. (2009). "On the physiology and pathophysiology of antimicrobial peptides." Mol Med 15(1-2): 51-9.

Papayannopoulos, V. and Zychlinsky, A. (2009). "NETs: a new strategy for using old weapons." Trends Immunol 30(11): 513-21.

Parham, P. (1995). "Evolutionary Immunology: A boost to immunity from nurse sharks." Current Biology 5(7): 696-699.

Parish, C. A., Jiang, H., Tokiwa, Y., Berova, N., Nakanishi, K., McCabe, D., Zuckerman, W., Xia, M. M. and Gabay, J. E. (2001). "Broad-spectrum antimicrobial activity of hemoglobin." Bioorg Med Chem 9(2): 377-82.

Park, C. B., Kim, M. S. and Kim, S. C. (1996). "A novel antimicrobial peptide from Bufo bufo gargarizans." Biochem Biophys Res Commun 218(1): 408-13.

Park, C. B., Yi, K. S., Matsuzaki, K., Kim, M. S. and Kim, S. C. (2000). "Structure-activity analysis of buforin II, a histone $\mathrm{H} 2 \mathrm{~A}$-derived antimicrobial peptide: the proline hinge is responsible for the cell-penetrating ability of buforin II." Proc Natl Acad Sci U S A 97(15): 8245-50.

Park, I. Y., Park, C. B., Kim, M. S. and Kim, S. C. (1998). "Parasin I, an antimicrobial peptide derived from histone H2A in the catfish, Parasilurus asotus." FEBS Lett 437(3): 258-62. 
Parseghian, M. H. and Luhrs, K. A. (2006). "Beyond the walls of the nucleus: the role of histones in cellular signaling and innate immunity." Biochem Cell Biol 84(4): 589-604.

Patat, S. A., Carnegie, R. B., Kingsbury, C., Gross, P. S., Chapman, R. and Schey, K. L. (2004). "Antimicrobial activity of histones from hemocytes of the Pacific white shrimp." Eur J Biochem 271(23-24): 4825-33.

Patrzykat, A., Zhang, L., Mendoza, V., Iwama, G. K. and Hancock, R. E. (2001). "Synergy of histone-derived peptides of coho salmon with lysozyme and flounder pleurocidin." Antimicrob Agents Chemother 45(5): 1337-42.

Petit, J. F. and Jolles, P. (1963). "Purification and Analysis of Human Saliva Lysozyme." Nature 200: 168-9.

Pettey, C. L. and McKinney, E. C. (1983). "Temperature and cellular regulation of spontaneous cytotoxicity in the shark." Eur J Immunol 13(2): 133-8.

Pruzanski, W. and Saito, S. G. (1969). "The diagnostic value of lysozyme (muramidase) estimation in biological fluids." Am J Med Sci 258(6): 405-15.

Putnam, F. W. (1975). Transferrin. The plasma proteins. F. W. Putnam. London, Academic Press. 1: 265-316.

Reddy, K. V., Shahani, S. K. and Meherji, P. K. (1996). "Spermicidal activity of Magainins: in vitro and in vivo studies." Contraception 53(4): 205-10.

Reif, W. E. (1978). "Wound healing in sharks. Form and arrangement of repair scales." Zoomorphologie 90: 101-111.

Relf, J. M., Chisholm, J. R., Kemp, G. D. and Smith, V. J. (1999). "Purification and characterization of a cysteine-rich 11.5-kDa antibacterial protein from the granular haemocytes of the shore crab, Carcinus maenas." Eur J Biochem 264(2): 350-7.

Richards, R. C., O'Neil, D. B., Thibault, P. and Ewart, K. V. (2001). "Histone H1: an antimicrobial protein of Atlantic salmon (Salmo salar)." Biochem Biophys Res Commun 284(3): 549-55. 
Rinehart, K. L., Holt, T. G., Fregeau, N. L., Keifer, P. A., Wilson, G. R., Perun, T. J., Jr., Sakai, R., Thompson, A. G., Stroh, J. G., Shield, L. S. and et al. (1990). "Bioactive compounds from aquatic and terrestrial sources." J Nat Prod 53(4): 771-92.

Rivas-Santiago, B., Sada, E., Tsutsumi, V., Aguilar-Leon, D., Contreras, J. L. and Hernandez-Pando, R. (2006). "beta-Defensin gene expression during the course of experimental tuberculosis infection." J Infect Dis 194(5): 697-701.

Rivas-Santiago, B., Serrano, C. J. and Enciso-Moreno, J. A. (2009). "Susceptibility to infectious diseases based on antimicrobial peptide production." Infect Immun 77(11): 4690-5.

Robinette, D., Wada, S., Arroll, T., Levy, M. G., Miller, W. L. and Noga, E. J. (1998). "Antimicrobial activity in the skin of the channel catfish /ctalurus punctatus: characterization of broadspectrum histone-like antimicrobial proteins." Cell Mol Life Sci 54(5): 467-75.

Rose, F. R., Bailey, K., Keyte, J. W., Chan, W. C., Greenwood, D. and Mahida, Y. R. (1998). "Potential role of epithelial cell-derived histone $\mathrm{H} 1$ proteins in innate antimicrobial defense in the human gastrointestinal tract." Infect Immun 66(7): 3255-63.

Rudikoff, S., Voss, E. W. and Sigel, M. M. (1970). "Biological and chemical properties of natural antibodies in the nurse shark." J Immunol 105(6): 1344-52.

Rumfelt, L. L., McKinney, E. C., Taylor, E. and Flajnik, M. F. (2002). "The development of primary and secondary lymphoid tissues in the nurse shark Ginglymostoma cirratum: B-cell zones precede dendritic cell immigration and T-cell zone formation during ontogeny of the spleen." Scand J Immunol 56(2): 130-48.

Sang, Y. and Blecha, F. (2008). "Antimicrobial peptides and bacteriocins: alternatives to traditional antibiotics." Anim Health Res Rev 9(2): 227-35.

Schittek, B., Hipfel, R., Sauer, B., Bauer, J., Kalbacher, H., Stevanovic, S., Schirle, M., Schroeder, K., Blin, N., Meier, F., Rassner, G. and Garbe, C. (2001). "Dermcidin: a novel human antibiotic peptide secreted by sweat glands." Nat Immunol 2(12): 1133-7.

Schnapp, D., Kemp, G. D. and Smith, V. J. (1996). "Purification and characterization of a prolinerich antibacterial peptide, with sequence similarity to bactenecin-7, from the haemocytes of the shore crab, Carcinus maenas." Eur J Biochem 240(3): 532-9. 
Schwartz, L. M. and Osborne, B. A. (1993). "Programmed cell death, apoptosis and killer genes." Immunol Today 14(12): 582-90.

Scott, M. G., Davidson, D. J., Gold, M. R., Bowdish, D. and Hancock, R. E. (2002). "The human antimicrobial peptide LL-37 is a multifunctional modulator of innate immune responses." J Immunol 169(7): 3883-91.

Selsted, M. E. (2004). "Theta-defensins: cyclic antimicrobial peptides produced by binary ligation of truncated alpha-defensins." Curr Protein Pept Sci 5(5): 365-71.

Selsted, M. E., Harwig, S. S., Ganz, T., Schilling, J. W. and Lehrer, R. I. (1985). "Primary structures of three human neutrophil defensins." J Clin Invest 76(4): 1436-9.

Senior, R. M., Campbell, E. J., Landis, J. A., Cox, F. R., Kuhn, C. and Koren, H. S. (1982). "Elastase of U-937 monocytelike cells. Comparisons with elastases derived from human monocytes and neutrophils and murine macrophagelike cells." J Clin Invest 69(2): 38493.

Seo, J. K., Stephenson, J., Crawford, J. M., Stone, K. L. and Noga, E. J. (2010). "American oyster, Crassostrea virginica, expresses a potent antibacterial histone H2B protein." Mar Biotechnol (NY) 12(5): 543-51.

Shin, D. H., Webb, B., Nakao, M. and Smith, S. L. (2007). "Molecular cloning, structural analysis and expression of complement component $\mathrm{Bf} / \mathrm{C} 2$ genes in the nurse shark, Ginglymostoma cirratum." Dev Comp Immunol 31(11): 1168-82.

Shin, D. H., Webb, B. M., Nakao, M. and Smith, S. L. (2009). "Characterization of shark complement factor I gene(s): genomic analysis of a novel shark-specific sequence." $\underline{\text { Mol }}$ Immunol 46(11-12): 2299-308.

Silphaduang, U., Hincke, M. T., Nys, Y. and Mine, Y. (2006). "Antimicrobial proteins in chicken reproductive system." Biochem Biophys Res Commun 340(2): 648-55.

Smith, M. M. (1991). "Histone structure and function." Curr Opin Cell Biol 3(3): 429-37. 
Smith, S. H. and Jensen, J. A. (1986). "The second component (C2n) of the nurse shark complement system: purification, physico-chemical characterization and functional comparison with guinea pig C4." Dev Comp Immunol 10(2): 191-206.

Smith, S. H., Obenauf, S. D. and Smith, D. S. (1989). "Fine structure of shark leucocytes during chemotactic migration." Tissue Cell 21(1): 47-58.

Spitznagel, J. K. (1984). "Nonoxidative antimicrobial reactions of leukocytes." Contemp Top Immunobiol 14: 283-343.

Spitznagel, J. K. (1990). "Antibiotic proteins of human neutrophils." J Clin Invest 86(5): 1381-6.

Steiner, H., Hultmark, D., Engstrom, A., Bennich, H. and Boman, H. G. (1981). "Sequence and specificity of two antibacterial proteins involved in insect immunity." Nature 292(5820): 246-8.

Steinstraesser, L., Kraneburg, U. M., Hirsch, T., Kesting, M., Steinau, H. U., Jacobsen, F. and AlBenna, S. (2009). "Host defense peptides as effector molecules of the innate immune response: a sledgehammer for drug resistance?" Int J Mol Sci 10(9): 3951-70.

Stephens, C., Kazan, K., Goulter, K. C., Maclean, D. J. and Manners, J. M. (2005). "The mode of action of the plant antimicrobial peptide MiAMP1 differs from that of its structural homologue, the yeast killer toxin WmKT." FEMS Microbiol Lett 243(1): 205-10.

Stokes, E. E. and Firkin, B. G. (1971). "Studies of the peripheral blood of the Port Jackson shark (Heterodontus portusjacksoni) with particular reference to the thrombocyte." $\mathrm{Br} \mathrm{J}$ Haematol 20(4): 427-35.

Sugiarto, H. and Yu, P. L. (2004). "Avian antimicrobial peptides: the defense role of betadefensins." Biochem Biophys Res Commun 323(3): 721-7.

Tang, Y. Q., Yuan, J., Miller, C. J. and Selsted, M. E. (1999). "Isolation, characterization, cDNA cloning, and antimicrobial properties of two distinct subfamilies of alpha-defensins from rhesus macaque leukocytes." Infect Immun 67(11): 6139-44. 
Tani, K., Murphy, W. J., Chertov, O., Salcedo, R., Koh, C. Y., Utsunomiya, I., Funakoshi, S., Asai, O., Herrmann, S. H., Wang, J. M., Kwak, L. W. and Oppenheim, J. J. (2000). "Defensins act as potent adjuvants that promote cellular and humoral immune responses in mice to a lymphoma idiotype and carrier antigens." Int Immunol 12(5): 691-700.

Tassanakajon, A., Amparyup, P., Somboonwiwat, K. and Supungul, P. (2010). "Cationic Antimicrobial Peptides in Penaeid Shrimp." Mar Biotechnol (NY).

Tomita, M., Takase, M., Bellamy, W. and Shimamura, S. (1994). "A review: the active peptide of lactoferrin." Acta Paediatr Jpn 36(5): 585-91.

Tsai, H. and Bobek, L. A. (1998). "Human salivary histatins: promising anti-fungal therapeutic agents." Crit Rev Oral Biol Med 9(4): 480-97.

Tsao, H. S., Spinella, S. A., Lee, A. T. and Elmore, D. E. (2009). "Design of novel histone-derived antimicrobial peptides." Peptides 30(12): 2168-73.

Tsugita, A. and Inouye, M. (1968). "Complete primary structure of phage lysozyme from Escherichia coli T4." J Mol Biol 37(1): 201-12.

Ursic-Bedoya, R. J., Nazzari, H., Cooper, D., Triana, O., Wolff, M. and Lowenberger, C. (2008). "Identification and characterization of two novel lysozymes from Rhodnius prolixus, a vector of Chagas disease." J Insect Physiol 54(3): 593-603.

Vizioli, J. and Salzet, M. (2002). "Antimicrobial peptides from animals: focus on invertebrates." Trends Pharmacol Sci 23(11): 494-6.

Wang, G., Li, X. and Wang, Z. (2009). "APD2: the updated antimicrobial peptide database and its application in peptide design." Nucleic Acids Res 37(Database issue): D933-7.

Wang, Y., Griffiths, W. J., Jornvall, H., Agerberth, B. and Johansson, J. (2002). "Antibacterial peptides in stimulated human granulocytes: characterization of ubiquitinated histone H1A." Eur J Biochem 269(2): 512-8.

Wardle, C. S. (1971). "New observations on the lymph system of the plaice Pleuronectes platessa and other teleosts." J Mar Biol Ass U.K. 51: 977-990. 
Watabe, Y., Kuramochi, H., Furuya, Y., Inagaki, N., Seino, S., Kimura, S. and Shimazaki, J. (1996). "Identification of histone H2A.X as a growth factor secreted by an androgenindependent subline of mouse mammary carcinoma cells." J Biol Chem 271(41): 2512630 .

Watson, K., Edwards, R. J., Shaunak, S., Parmelee, D. C., Sarraf, C., Gooderham, N. J. and Davies, D. S. (1995). "Extra-nuclear location of histones in activated human peripheral blood lymphocytes and cultured T-cells." Biochem Pharmacol 50(3): 299-309.

Weinberg, E. D. (1974). "Iron and susceptibility to infectious disease." Science 184(140): 952-6.

Wiedow, O. and Meyer-Hoffert, U. (2005). "Neutrophil serine proteases: potential key regulators of cell signalling during inflammation." J Intern Med 257(4): 319-28.

Wong, J. H., Xia, L. and Ng, T. B. (2007). "A review of defensins of diverse origins." Curr Protein Pept Sci 8(5): 446-59.

Wong, K. F. and Luk, J. M. (2009). "Endotoxin-neutralizing peptides as gram-negative sepsis therapeutics." Protein Pept Lett 16(5): 539-42.

Wu, Y., He, K., Ludtke, S. J. and Huang, H. W. (1995). "X-ray diffraction study of lipid bilayer membranes interacting with amphiphilic helical peptides: diphytanoyl phosphatidylcholine with alamethicin at low concentrations." Biophys J 68(6): 2361-9.

Yang, D., Biragyn, A., Kwak, L. W. and Oppenheim, J. J. (2002). "Mammalian defensins in immunity: more than just microbicidal." Trends Immunol 23(6): 291-6.

Yokoyama, H. O. (1960). "Studies on the origin, development and seasonal variations in the blood cells of the perch, Perca flavescens." Wild Life Disease 6: 1-103.

Yoshio, H., Lagercrantz, H., Gudmundsson, G. H. and Agerberth, B. (2004). "First line of defense in early human life." Semin Perinatol 28(4): 304-11.

Zairi, A., Tangy, F., Bouassida, K. and Hani, K. (2009). "Dermaseptins and magainins: antimicrobial peptides from frogs' skin-new sources for a promising spermicides microbicides-a mini review." J Biomed Biotechnol 2009: 452567. 
Zanetti, M., Gennaro, R. and Romeo, D. (1995). "Cathelicidins: a novel protein family with a common proregion and a variable C-terminal antimicrobial domain." FEBS Lett 374(1): 15.

Zapata, A. (1981). "Ultrastructure of Elasmobranch Lymphoid-Tissue .2. Leydig and Epigonal Organs." Developmental and Comparative Immunology 5(1): 43-52.

Zasloff, M. (1987). "Magainins, a class of antimicrobial peptides from Xenopus skin: isolation, characterization of two active forms, and partial cDNA sequence of a precursor." Proc Natl Acad Sci U S A 84(15): 5449-53.

Zasloff, M., Martin, B. and Chen, H. C. (1988). "Antimicrobial activity of synthetic magainin peptides and several analogues." Proc Natl Acad Sci U S A 85(3): 910-3.

Zeya, H. I. and Spitznagel, J. K. (1966). "Cationic proteins of polymorphonuclear leukocyte Iysosomes. I. Resolution of antibacterial and enzymatic activities." J Bacteriol 91(2): 750 4.

Zhang, Y. X. and Chen, S. L. (2006). "Molecular identification, polymorphism, and expression analysis of major histocompatibility complex class IIA and B genes of turbot (Scophthalmus maximus)." Mar Biotechnol (NY) 8(6): 611-23.

Zhu, S. (2007). "Evidence for myxobacterial origin of eukaryotic defensins." Immunogenetics 59(12): 949-54.

Zlatanova, J. S., Srebreva, L. N., Banchev, T. B., Tasheva, B. T. and Tsanev, R. G. (1990). "Cytoplasmic pool of histone H1 in mammalian cells." J Cell Sci 96 ( Pt 3): 461-8. 


\section{APPENDIX I}

\subsection{Preparation of Buffers, Stock Solutions and Media}

Buffers and stock solutions were filtered through a 0.45 micron Nalgene filter before use. Unless otherwise stated, all sterilization of liquids and culture media was carried out in an autoclave at $121^{\circ} \mathrm{C}$ for 20 min under $15 \mathrm{lbs}$. pressure. Autoclaved material was cooled to room temperature before storage at $4^{\circ} \mathrm{C}$ or stored at room temperature (RT). Solutions were prepared as follows:

$0.5 \mathrm{M}$ sodium phosphate $\left(\mathrm{Na} \mathrm{H}_{2} \mathrm{PO}_{4}\right)$-acidic solution:

- $34.5 \mathrm{~g} \mathrm{Na} \mathrm{H} \mathrm{PO}_{4}$, dry weight (Sigma, $\mathrm{MO}$ ) was added to sterile deionized distilled (dd) water $\left(\mathrm{H}_{2} \mathrm{O}\right)$ and the volume brought up to $500 \mathrm{ml}$.

$0.5 \mathrm{M}$ sodium phosphate $\left(\mathrm{Na}_{2} \mathrm{HPO}_{4}\right)$-basic solution:

- $\quad 35.5 \mathrm{~g} \mathrm{Na}_{2} \mathrm{HPO}_{4}$, dry weight (Sigma, MO) was added to sterile $\mathrm{ddH}_{2} \mathrm{O}$ and the volume brought up to $500 \mathrm{ml}$ until salt completely dissolved.

Stock $0.5 \mathrm{M}$ sodium phosphate (PB), $\mathrm{pH} 7.5$

- $\quad 0.5 \mathrm{M}$ sodium phosphate buffer of $\mathrm{pH} 7.5$ was prepared by mixing appropriate volumes of $0.5 \mathrm{M}$ acid and base sodium phosphate stock solutions. To attain a $\mathrm{pH}$ of 7.5, $95 \mathrm{ml}$ of the acid was added to approximately $500 \mathrm{ml}$ of the base.

Phosphate buffered saline $\left(0.005 \mathrm{M} \mathrm{NaPO}_{4}, 0.14 \mathrm{M} \mathrm{NaCl}, \mathrm{pH} 7.3\right)$

- $2 \mathrm{~g} \mathrm{NaCl}$ (Fisher Scientific, GA) was added to 0.005M PB (diluted 1:100 from stock), and the mixture stirred until completely dissolved. The $\mathrm{pH}$ was adjusted 
to 7.3 with $1 \mathrm{~N} \mathrm{HCl}$ (approximately 5 drops). The final volume was adjusted to 250 $\mathrm{ml}$ with the diluted PB. The buffer was then sterilized.

Shark phosphate buffered saline (0.05 $\mathrm{M} \mathrm{NaPO}_{4}, 0.35 \mathrm{M}$ urea, $\left.0.2 \mathrm{M} \mathrm{NaCl}, \mathrm{pH} 7.3\right)$

- $1.17 \mathrm{~g} \mathrm{NaCl}$ (Fisher Scientific, GA) and 2.1g urea (Fisher Scientific, GA) was added to $0.5 \mathrm{M} \mathrm{PB}$ (diluted 1:10 from stock) and the mixture stirred until completely dissolved. The $\mathrm{pH}$ was adjusted to 7.3 with $1 \mathrm{~N} \mathrm{HCl}$ and the final volume was adjusted to $100 \mathrm{ml}$ with the diluted PB before sterilization.

Shark RPMI medium (RPMI 1640 containing $0.35 \mathrm{M}$ urea, $0.2 \mathrm{M} \mathrm{NaCl}$ )

- This isotonic medium for shark blood cells was prepared by dissolving $3.5 \mathrm{~g} \mathrm{NaCl}$ and 6.3g urea (Fisher Scientific, GA) in $300 \mathrm{ml}$ RPMI 1640 medium (Gibco/ Invitrogen, $C A$ ), containing $0.025 \mathrm{M}$ Hepes Buffer with L-glutamine, 0.1 micron filtered, $\mathrm{pH}$ 7.3. The medium was further sterilized by filtration through 0.45 micron Nalgene filter and stored at $4^{\circ} \mathrm{C}$.

$0.25 \mathrm{M} \mathrm{NaCl}$ solution

- An isotonic salt solution was used for suspending shark leukocytes and was prepared by dissolving $3.65 \mathrm{~g}$ of $\mathrm{NaCl}$ in $250 \mathrm{ml}$ of $\mathrm{ddH}_{2} \mathrm{O}$ and sterilized.

\section{$3.2 \% \mathrm{NaCl}$ solution}

- This solution was used for washing salt tolerant bacterial stock culture and was prepared by dissolving $3.2 \mathrm{~g}$ of $\mathrm{NaCl}$ in $100 \mathrm{ml}$ of $\mathrm{ddH}_{2} \mathrm{O}$ and sterilizing. 


\section{$0.2 \% \mathrm{NaCl}$ solution}

- This hypotonic solution was used to lyse contaminating erythrocytes present in shark leukocytes isolated from whole blood, and was prepared by dissolving 0.2 $\mathrm{g}$ of $\mathrm{NaCl}$ in $100 \mathrm{ml}$ of $\mathrm{ddH}_{2} \mathrm{O}$ and sterilizing.

\section{$2.5 \% \mathrm{NaCl}$ solution}

- This hypertonic solution was used to neutralize the hypotonic salt solution during lysis of RBC's in shark leukocyte suspensions and was prepared by dissolving $2.5 \mathrm{~g}$ of $\mathrm{NaCl}$ in $100 \mathrm{ml}$ of $\mathrm{dd}_{2} \mathrm{O}$ and sterilizing.

$0.06 \mathrm{M}$ phosphate buffer $\left(0.06 \mathrm{M} \mathrm{NaPO}_{4}\right.$, variable $\left.\mathrm{pH}\right)$

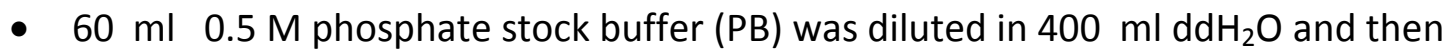
the $\mathrm{pH}$ was adjusted, using $1 \mathrm{~N} \mathrm{NaOH} / 1 \mathrm{~N} \mathrm{HCl}$. The volume was brought up to 500 $\mathrm{ml}$ before sterilization.

$0.06 \mathrm{M}$ phosphate buffer- $\mathrm{NaCl}\left(0.06 \mathrm{M} \mathrm{NaPO}_{4}, 0.14 \mathrm{M} \mathrm{NaCl}\right.$, variable $\left.\mathrm{pH}\right)$

- $\quad 0.818 \mathrm{~g} \mathrm{NaCl}$ was diluted in $80 \mathrm{ml}$ of $0.06 \mathrm{M} \mathrm{PB}$ and then the $\mathrm{pH}$ was adjusted using $1 \mathrm{~N} \mathrm{NaOH} / 1 \mathrm{~N} \mathrm{HCl}$.The volume was brought up to $100 \mathrm{ml}$ before sterilization.

Artificial sea water salt solution $5 x$ stock $\left(2.585 \mathrm{M} \mathrm{NaCl}, 0.125 \mathrm{M} \mathrm{MgSO}_{4}, 0.125 \mathrm{M} \mathrm{MgCl}_{2}\right.$, $0.05 \mathrm{M} \mathrm{KCl}, \mathrm{pH} 7.5)$

- $151.06 \mathrm{~g} \mathrm{NaCl}, 15.05 \mathrm{~g} \mathrm{MgSO}_{4}, 25.41 \mathrm{~g} \mathrm{MgCl}_{2}$, and $3.73 \mathrm{~g} \mathrm{KCl}$ (Sigma, MO) were added to $\mathrm{ddH}_{2} \mathrm{O}$, and after the $\mathrm{pH}$ was adjusted to 7.5 , using $1 \mathrm{~N} \mathrm{NaOH} / 1 \mathrm{~N} \mathrm{HCl}$, 
the volume brought up to $1000 \mathrm{ml}$. The stock solution was diluted five-fold to obtain a $1 x$ working solution used to prepare media.

\subsection{Staining Solutions}

Modified Coomassie stain ( $23.47 \%$ methanol, $13 \%$ formaldehyde), used for staining radial diffusion assay plates, was prepared by,

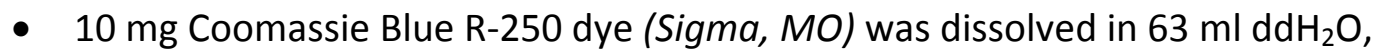
$27 \mathrm{ml}$ methanol (Fisher Scientific, GA) and $15 \mathrm{ml} 37 \%$ formaldehyde (Sigma, MO) to give a total volume of $115 \mathrm{ml}$. The solution was stored in a dark bottle at room temperature.

Modified Coomassie destain (10\% acetic acid, 2\% dimethylsulfonate-DMSO)

- $50 \mathrm{ml}$ glacial acetic acid (Fisher Scientific, GA) and $10 \mathrm{ml}$ DMSO (Sigma, MO) was

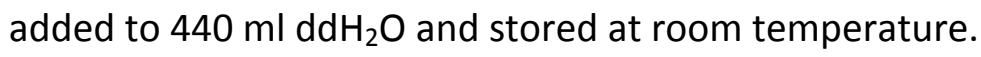

Laemmli Coomassie stain for staining SDS-PAGE gels.

- $\quad 1.875$ g Coomassie Blue R-250 dye (Sigma, MO) was dissolved in a mixture of 227 $\mathrm{ml}$ methanol (Fisher Scientific, GA) and $94 \mathrm{ml}$ glacial acetic acid (Sigma, MO) and the volume adjusted with $179 \mathrm{ml} \mathrm{ddH_{2 }} \mathrm{O}$. The solution was stored at room temperature. 
Modified Laemmli Coomassie destain for SDS-PAGE gels.

- $100 \mathrm{ml}$ glacial acetic acid (Fisher Scientific, GA), $375 \mathrm{ml}$ methanol (Sigma, MO)

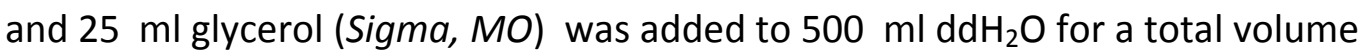
of $1000 \mathrm{ml}$ and stored at room temperature.

Modified Coomassie stain for staining PVDF membranes.

- $0.02 \mathrm{~g}$ Coomassie Blue R-250 dye (Sigma, MO) was dissolved in a mixture of $40 \mathrm{ml}$

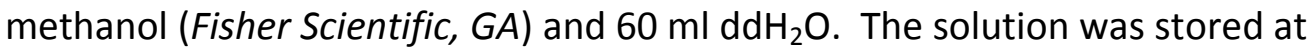
room temperature.

\subsection{Electrophoresis Solutions and Buffers}

Electrophoresis 10X stock buffer (Oxford formula)

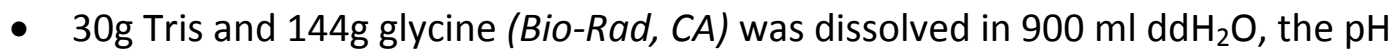
was adjusted to 8.8 with $1 \mathrm{~N} \mathrm{NaOH} / 1 \mathrm{~N} \mathrm{HCl}$ and the total volume was adjusted to $1000 \mathrm{ml}$ with $\mathrm{ddH}_{2} \mathrm{O}$. The solution was filter sterilized ( 0.4 micron), and stored at $4^{\circ} \mathrm{C}$.

Electrophoresis $1 \mathrm{X}$ running buffer-SDS

- $10 \mathrm{ml} 10 \%$ SDS ((Sigma, MO) was added to $100 \mathrm{ml}$ 10X Electrophoresis buffer diluted in $700 \mathrm{ml} \mathrm{ddH_{2 }} \mathrm{O}$. The $\mathrm{pH}$ was adjusted to 8.8 with $1 \mathrm{~N} \mathrm{NaOH} / 1 \mathrm{~N} \mathrm{HCl}$ and the total volume was brought up to $1000 \mathrm{ml}$. 
Sample buffer for SDS-PAGE (5X non-reducing)

- $0.6 \mathrm{ml} 1 \mathrm{M}$ Tris- $\mathrm{HCl}, \mathrm{pH} 6.8,5 \mathrm{ml} 50 \%$ glycerol (Sigma, MO) in ddH $\mathrm{H}_{2} \mathrm{O}, 2 \mathrm{ml} 10 \%$

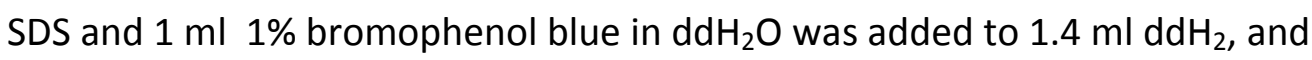
filter sterilized (0.4 micron), and stored at $-20^{\circ} \mathrm{C}$.

Sample buffer for SDS-PAGE ( $5 \mathrm{X}$ reducing)

- $0.6 \mathrm{ml} 1 \mathrm{M}$ Tris- $\mathrm{HCl}, \mathrm{pH} 6.8,5 \mathrm{ml} 50 \%$ glycerol in $\mathrm{ddH}_{2} \mathrm{O}, 2 \mathrm{ml} 10 \%$ SDS, $0.5 \mathrm{ml} 2$ mercaptoethanol (Sigma, MO) and $1 \mathrm{ml}$ 1\% bromophenol blue (Sigma, MO) in

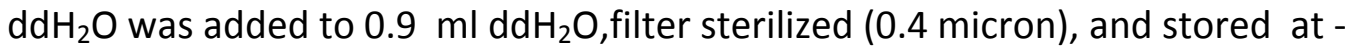
$20^{\circ} \mathrm{C}$.

$30 \%$ acrylamide and $0.8 \%$ bis-acrylamide

- $30 \mathrm{~g}$ acrylamide and $0.8 \mathrm{~g}$ bis-acrylamide (Sigma, $\mathrm{MO}$ ) were very carefully added to $100 \mathrm{ml} \mathrm{ddH_{2 }} \mathrm{O}$ and mixed. The solution was stored in a dark bottle at $4{ }^{\circ} \mathrm{C}$.

$60 \%$ acrylamide and $1.6 \%$ bis-acrylamide

- $60 \mathrm{~g}$ acrylamide and $1.6 \mathrm{~g}$ bis-acrylamide (Sigma, MO) were very carefully added to

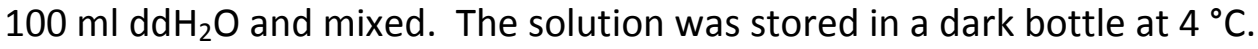

Resolving buffer- 1.5M Tris- $\mathrm{HCl}(\mathrm{pH} 8.8)$

- $75 \mathrm{ml} 2 \mathrm{M}$ Tris-HCl, pH 8.8 (Fisher Scientific, GA) and 4ml 10\% SDS were added

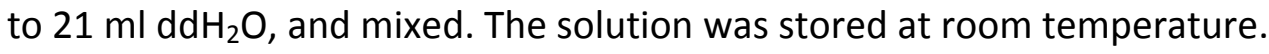

Stacking buffer- $0.5 \mathrm{M}$ Tris-HCl (pH 6.8)

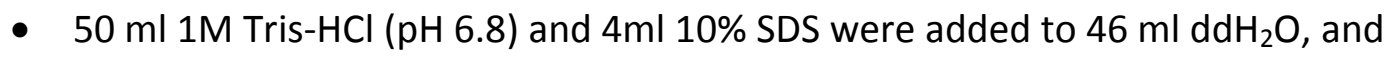
mixed. The solution was stored at room temperature 
Acid-urea electrophoresis buffer-5\% acetic acid

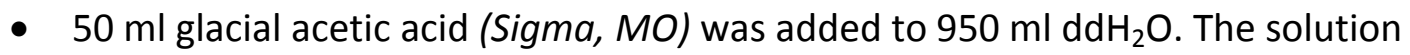
was filter sterilized (0.4 micron) and stored at $4^{\circ} \mathrm{C}$.

Acid-urea sample buffer-9M urea in 5\% acetic acid

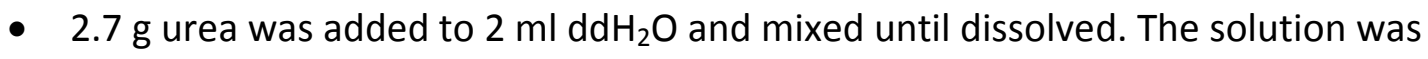
then mixed with AG501-X8 resin (Bio-Rad, CA) to deionize for $20 \mathrm{~min}$. The solution was decanted, $0.25 \mathrm{ml}$ glacial acetic acid was added and the volume was adjusted to $5 \mathrm{ml}$ final volume with $\mathrm{ddH}_{2} \mathrm{O}$. $0.1 \mathrm{~g}$ methyl green was added to the final solution, which was filter sterilized $\left(0.4\right.$ micron) and stored at $-20^{\circ} \mathrm{C}$.

Acid-urea gel wash buffer-0.01 $\mathrm{M} \mathrm{NaPO}_{4}, \mathrm{pH} 7.5$

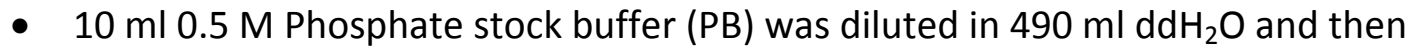
the $\mathrm{pH}$ was adjusted, using $1 \mathrm{~N} \mathrm{NaOH} / 1 \mathrm{~N} \mathrm{HCl}$. The buffer was then sterilized.

\subsection{Chromatography Buffers}

For ion exchange chromatography, the following buffers were employed:

Equilibration buffer: $0.02 \mathrm{M}$ Tris- $\mathrm{HCl}, 0.05 \mathrm{M} \mathrm{NaCl}, \mathrm{pH} 7.5$

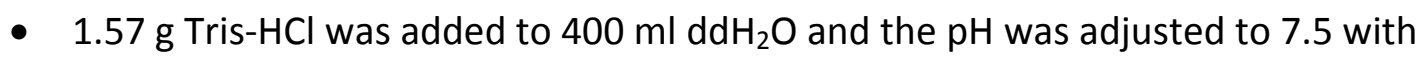
$1 \mathrm{~N} \mathrm{NaOH}$. The final volume was adjusted to $500 \mathrm{ml}$ with $\mathrm{ddH}_{2} \mathrm{O}$ and the buffer filter sterilized. 
Elution buffer A: $0.02 \mathrm{M}$ Tris- $\mathrm{HCl}, 0.5 \mathrm{M} \mathrm{NaCl}, \mathrm{pH} 7.5$

- $11.69 \mathrm{~g} \mathrm{NaCl}$ was added to $400 \mathrm{ml} 0.02 \mathrm{M}$ Tris- $\mathrm{HCl}$, the $\mathrm{pH}$ adjusted to 7.5 with $1 \mathrm{~N}$ $\mathrm{NaOH}$ and the final volume adjusted to $500 \mathrm{ml}$ with $\mathrm{ddH}_{2} \mathrm{O}$ before the buffer was filter sterilized.

Elution buffer B: $0.02 \mathrm{M}$ Tris- $\mathrm{HCl}, 1.0 \mathrm{M} \mathrm{NaCl}, \mathrm{pH} 7.5$

- $11.69 \mathrm{~g} \mathrm{NaCl}$ was added to $200 \mathrm{ml}$ of $0.02 \mathrm{M}$ Tris- $\mathrm{HCl}$, the $\mathrm{pH}$ was adjusted to 7.5 with $1 \mathrm{~N} \mathrm{NaOH}$ and the final volume adjusted to $250 \mathrm{ml}$ with $\mathrm{ddH}_{2} \mathrm{O}$ before the buffer was filter sterilized.

For heparin affinity chromatography, the following buffers were employed:

Equilibration buffer: $0.1 \mathrm{M}$ Tris, $0.01 \mathrm{M}$ Citric acid, $0.075 \mathrm{M} \mathrm{NaCl}, \mathrm{pH} 7.5$

- $\quad 12.11 \mathrm{~g}$ Trizma base (Sigma, MO), $1.47 \mathrm{~g}$ citric acid (Fisher Scientific, GA) and

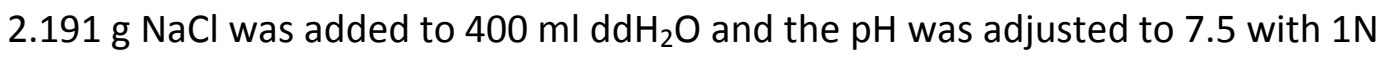
$\mathrm{NaOH}$. The final volume was adjusted to $500 \mathrm{ml}$ with $\mathrm{ddH}_{2} \mathrm{O}$ and the buffer filter sterilized.

Elution buffer: $0.1 \mathrm{M}$ Tris, $0.01 \mathrm{M}$ citric acid, $2 \mathrm{M} \mathrm{NaCl}$, pH 7.5

- $\quad 12.11 \mathrm{~g}$ Trizma base (Sigma, MO), $1.47 \mathrm{~g}$ citric acid (Fisher Scientific, GA) and

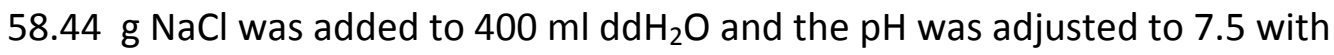
$1 \mathrm{~N} \mathrm{NaOH}$. The final volume was adjusted to $500 \mathrm{ml}$ with $\mathrm{dd}_{2} \mathrm{O}$ and the buffer filter sterilized. 


\subsection{Culture Media}

Double-strength Artificial Sea Water Complete Broth (2x SCM), pH 7.5

- $5 \mathrm{~g}$ peptone, $1 \mathrm{~g}$ yeast extract, $3 \mathrm{ml}$ glycerol, and $0.2 \mathrm{~g}$ glycerol phosphate were added to $400 \mathrm{ml}$ of single strength artificial sea water salt solution (see above), and the mixture stirred and heated until dissolved. The $\mathrm{pH}$ was adjusted to 7.5 with $1 \mathrm{~N} \mathrm{NaOH}$ and the volume made up to $500 \mathrm{ml}$. The broth was aliquoted ( 250 $\mathrm{ml}$ ) to screw cap conical flasks, sterilized and stored at $4{ }^{\circ} \mathrm{C}$.

Artificial Sea Water Complete Broth (1x SCM), pH 7.5

- $5 \mathrm{~g}$ peptone, $1 \mathrm{~g}$ yeast extract (Difco, $M I), 3 \mathrm{ml}$ glycerol, and $0.2 \mathrm{~g}$ glycerol phosphate (Sigma, MO) was dissolved in $1 \mathrm{x}$ artificial sea water salt solution ( 5 fold diluted stock) solution. The $\mathrm{pH}$ was adjusted to 7.5 with $10 \mathrm{~N} \mathrm{NaOH}$, and the volume brought up to $1000 \mathrm{ml}$ with $1 \mathrm{x}$ artificial sea water. Aliquots $(50 \mathrm{ml})$ were sterilized in $125 \mathrm{ml} \mathrm{screw}$ cap conical flasks and stored at $4^{\circ} \mathrm{C}$.

$1 \%$ agar underlay with $0.02 \%$ Tween 20 for agar diffusion assay

- $2 \mathrm{~g}$ dehydrated agarose (Sigma, MO) was dissolved in $200 \mathrm{ml}$ of $0.005 \mathrm{M} \mathrm{PBS,} \mathrm{pH}$ 7.5, by heating the mixture. $20 \mu$ l Tween 20 (Bio-Rad, CA) was added to the mixture and the agar sterilized, cooled to $44^{\circ} \mathrm{C}$ in a water bath and dispensed as $10 \mathrm{ml}$ aliquots into sterile $20 \mathrm{ml}$ screw cap tubes and stored at $25^{\circ} \mathrm{C}$ (room temperature). 
$1 \%$ agar overlay with SCM

- $2 \mathrm{~g}$ dehydrated agarose (Sigma, MO) was added to $2 \mathrm{x}$ artificial sea water complete broth, and the mixture heated to dissolve the agar which was sterilized and cooled to $44^{\circ} \mathrm{C}$ in a water bath. The agar medium was dispensed as $10 \mathrm{ml}$ aliquots into sterile $20 \mathrm{ml}$ screw cap tubes which were stored at $25^{\circ} \mathrm{C}$ (room temperature).

$2 \%$ agarose in $0.06 \mathrm{M} \mathrm{PB}, \mathrm{pH} 6.2$

- $4 \mathrm{~g}$ dehydrated agarose was dissolved in $200 \mathrm{ml}$ of $0.06 \mathrm{M} \mathrm{PB}, \mathrm{pH} 6.2$, by heating and sterilized before dispensing as aliquots $(100 \mathrm{ml})$ to $125 \mathrm{ml}$ screw cap conical flasks. Used in the preparation of lysoplates.

Tryptic Soy Broth

- $30 \mathrm{~g}$ dehydrated tryptic soy broth powder (Difco, MI) was suspended in $1 \mathrm{~L}$ $\mathrm{ddH}_{2} \mathrm{O}$ and warmed slightly to dissolve. The broth was aliquoted $(50 \mathrm{ml})$ to screw cap conical flasks, sterilized and stored at room temperature.

Tryptic Soy Agar

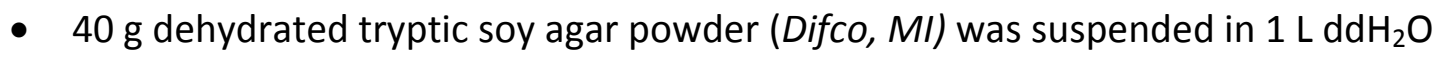
and warmed slightly to dissolve. The broth was aliquoted (15 $\mathrm{ml}$ ) to screw cap conical flasks, sterilized and stored as slants at room temperature. 


\subsection{Reagents}

$3.8 \%$ Trisodium citrate (anticoagulant)

- $1.9 \mathrm{~g}$ trisodium citrate (Sigma, $\mathrm{MO}$ ) was dissolved in $50 \mathrm{ml}$ shark RPMI, $\mathrm{pH}$ 7.37.5, and filter sterilized with a 0.45 micron Nalgene filter.

Human Neutrophil Peptide 1, HNP1

- Lyophilized pellet (Sigma, MO) reconstituted to $25 \mathrm{ug} / \mathrm{ml}$ in sterile $\mathrm{dd}_{2} \mathrm{O}$. This served as an antibacterial control in antibacterial assays.

Chicken egg white lysozyme

- A $1 \mathrm{mg} / \mathrm{ml}$ stock solution of chicken egg white lysozyme (muramidase) EC

3.2.1.17 (Sigma, MO) was prepared in $\mathrm{dd}_{2} \mathrm{O}$, and diluted 1:100 (final concentration: $0.01 \mathrm{mg} / \mathrm{ml}$ ) to use as a positive control in lysozyme assay plates (lysoplates).

Cell viability test reagent

- An isotonic reagent for shark leukocytes consisting of $0.1 \%$ trypan blue in $0.25 \mathrm{M}$ $\mathrm{NaCl}$ was prepared by dissolving $0.05 \mathrm{~g}$ trypan blue stain in $50 \mathrm{ml} 0.25 \mathrm{M} \mathrm{NaCl}$. The solution was filtered and stored in $1 \mathrm{ml}$ aliquots at RT.

\subsection{Polyacrylamide Gels}

Native-PAGE resolving gel (7.5\%)

- $2.5 \mathrm{ml} \mathrm{30 \%}$ acrylamide:0.8\% bis-acrylamide (Sigma, MO), $2.5 \mathrm{ml} 1.5 \mathrm{M}$ Tris- $\mathrm{HCl}$,

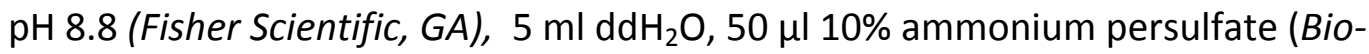


Rad, CA) and $10 \mu$ I TEMED (Bio-Rad, CA) were gently swirled together until mixed. This mixture was immediately pipetted into assembled gel cassettes (BioRad, CA) and allowed to polymerize at room temperature for $1 \mathrm{~h}$.

Native-PAGE resolving gel (10\%)

- $\quad 3.33 \mathrm{ml} \mathrm{30 \%}$ acrylamide:0.8\% bis-acrylamide (Sigma, MO), $2.5 \mathrm{ml} 1.5 \mathrm{M}$ Tris- $\mathrm{HCl}$,

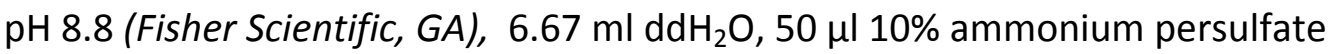
(Bio-Rad, CA) and $5 \mu$ I TEMED (Bio-Rad, CA) were gently swirled together until mixed. This mixture was immediately pipetted into assembled gel cassettes (BioRad, CA) and allowed to polymerize at room temperature for $1 \mathrm{~h}$.

Native-PAGE stacking gel (5\%)

- $0.67 \mathrm{ml} 30 \%$ acrylamide:0.8\% bis-acrylamide (Sigma, MO), $1 \mathrm{ml} 0.5 \mathrm{M}$ Tris- $\mathrm{HCl}$,

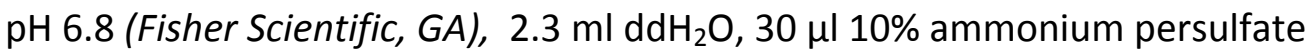
(Bio-Rad, CA) and $5 \mu$ I TEMED (Bio-Rad, CA) were gently swirled together until mixed. This mixture was immediately pipetted into assembled gel cassettes (Bio$\mathrm{Rad}, \mathrm{CA}$ ) on top of resolving gel and allowed to polymerize with appropriate sized combs at room temperature for $30 \mathrm{~m}$ Polymerized gels were stored at $4{ }^{\circ} \mathrm{C}$ until ready to use. 


\subsection{Acid-Urea Gels}

Acid-urea gel (12.5\%)

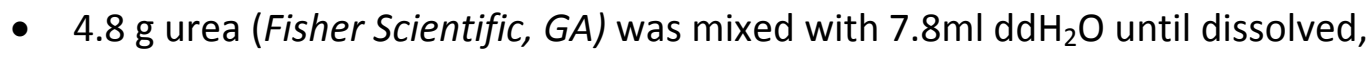
then $3.34 \mathrm{ml} 60 \%$ acrylamide:1.6\% bis-acrylamide (Sigma, MO), $0.87 \mathrm{ml}$ glacial acetic acid (Fisher Scientific, GA), $0.30 \mathrm{ml} \mathrm{10 \%} \mathrm{APS} \mathrm{(Bio-Rad,} \mathrm{CA)} \mathrm{and} 0.12 \mathrm{Ml}$ TEMED (Bio-Rad, CA) were added and gently swirled until mixed. This mixture was immediately pipetted into assembled gel cassettes (Bio-Rad, CA) and allowed to polymerize at $30^{\circ} \mathrm{C}$ with appropriate sized combs for up to 2 hours. Polymerized gels were stored at $4{ }^{\circ} \mathrm{C}$ until ready to use.

\subsection{Target Bacteria for antibacterial assays}

The following bacterial cultures were used as target organisms in antibacterial assays:

- Planococcus citreus (NCIMB 1493) was the target organism used in the antibacterial assay s and was kindly provided by Dr. Valerie Smith, St. Andrews University, Scotland. The organism has been shown to be a problem in commercial shrimp culture implicated in shrimp spoilage (Alvarez et al. 1981).

\subsection{Cell Walls for muramidase activity}

The following cell wall preparation was used as target organism in lysozyme assays:

- $\quad$ Iyophilized suspension of cell walls of Micrococcus lysodeikticus (ATCC 4698) was used as the substrate for muramidase (lysozyme) activity in lysoplates. 


\subsection{Western Blot Buffers and Reagents}

Transfer buffer

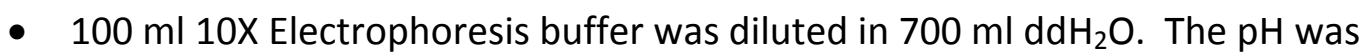
adjusted to 8.8 with $1 \mathrm{~N} \mathrm{NaOH} / 1 \mathrm{~N} \mathrm{HCl}$ and the total volume was brought up to $900 \mathrm{ml}$.

- $100 \mathrm{ml}$ methanol was added to the buffer (to facilitate transfer of smaller proteins) and mixed. The buffer was stored at $4{ }^{\circ} \mathrm{C}$.

Blocking solution-5\% nonfat dried milk

- A 5\% nonfat dried milk solution was prepared by dissolving $50 \mathrm{~g}$ nonfat dried milk (Carnation) in $1 \mathrm{LddH_{2 }}$ O. Fresh blocking solution was prepared each time.

Tris buffered saline (TBS)

- $11.69 \mathrm{~g} \mathrm{NaCl}$ was added to $400 \mathrm{ml} 0.02 \mathrm{M}$ Tris- $\mathrm{HCl}$ and the $\mathrm{pH}$ adjusted to 7.5 with $1 \mathrm{~N} \mathrm{NaOH}$, and the final volume adjusted to $500 \mathrm{ml}$ with $\mathrm{dd}_{2} \mathrm{O}$ before the buffer was filter sterilized.

Wash diluent buffer-1\% milk in TBS with Tween 20

- $10 \mathrm{~g}$ nonfat dried milk was added to $1 \mathrm{~L}$ TBS and mixed until dissolved. $100 \mu \mathrm{l}$ Tween 20 (Bio-Rad, CA) was added and solution stored at $4{ }^{\circ} \mathrm{C}$.

Antibody buffer-1\% milk in TBS

- $1 \mathrm{~g}$ nonfat dried milk was added to $100 \mathrm{ml}$ TBS and mixed until dissolved and solution stored at $4{ }^{\circ} \mathrm{C}$. 
Rabbit anti-human $\mathrm{H} 4$ polyclonal antisera

- Affinity-purified rabbit anti-acetyl-histone H4 (Sigma, MO) antibody was diluted 1:750 in antibody buffer and stored at $4{ }^{\circ} \mathrm{C}$.

Rabbit anti-human HDAC4 (H4) polyclonal antisera

- Affinity purified rabbit anti-histone deacetylase 4 (Sigma, MO) antibody was diluted 1:1000 in antibody buffer and stored at $4{ }^{\circ} \mathrm{C}$.

Rabbit anti-human HDAC2 (H2) polyclonal antisera

- Affinity purified rabbit anti-histone deacetylase 2 (Sigma, MO) antibody was diluted 1:2000 in antibody buffer and stored at $4{ }^{\circ} \mathrm{C}$.

Rabbit anti-hen egg white lysozyme polyclonal antisera

- Rabbit anti-HEWL (Rockland, PA) was diluted 1:1000 in antibody buffer and stored at $4{ }^{\circ} \mathrm{C}$.

Peroxidase conjugated goat anti-rabbit IgG antisera

- Goat anti-rabbit IgG (Rockland, PA) was diluted 1:1000 in antibody buffer and stored at $4{ }^{\circ} \mathrm{C}$.

Horseradish peroxidase (HRP) conjugate substrate kit

- The kit (Bio-Rad, CA) was assembled according to the manufacturer's instructions: $600 \mu \mathrm{l} \mathrm{HRP}$ color reagent B (containing hydrogen peroxide) was added to $100 \mathrm{ml}$ of $1 \times$ HRP color development buffer at RT. This solution was added to $20 \mathrm{ml}$ of HRP color reagent A (containing 4-chloro-1-naphthol in diethylene glycol) and reagent used immediately. 


\section{VITA}

Nichole Hinds Vaughan

September 25, 1973

1995

1996

2000

2001-2006

2003

AWARDS AND DISTINCTIONS

1991-1995

1998

2002-2004
Born, St. Andrews, Jamaica

B.S.C., Biology

University of Miami

Miami, FL

Certificate in Clinical and Diagnostic Microbiology

Medical Technology

Florida International University

Miami, FL

M.S., Medical Laboratory Sciences

Florida International University

Miami, FL

Teaching Assistant

Florida International University

Miami, FL

Certificate in Comparative Immunology

MBRS

Florida International University

Miami, FL
Bowman Ashe Scholarship

University of Miami

Miami, FL

$1^{\text {st }}$ prize, Student presentations

Graduate Student Association's Scholarly Forum

Florida International University

Miami, FL

Summer Research Award in Comparative Immunology MBRS/RISE

Florida International University 
2006, 2008-2009

BRI Summer Research Award

MBRS/RISE

Florida International University

Miami, FL

2007

Vice President

Graduate Student Association

Florida International University

Miami, FL

2008-2011

MBRS/RISE Fellowship

Florida International University

Miami, FL

\section{PUBLICATIONS AND PRESENTATIONS}

Hinds, N., Smith, S.L. (2001). Antibacterial activity of shark leukocyte lysates, Federation of American Societies for Experimental Biology Journal, 15(4).

Hinds, N., Smith, S.L. (2003). Antibacterial activity of associated with histone fragments present in shark leukocyte lysates, Paper presented at the $9^{\text {th }}$ Congress of the International Society for Developmental and Comparative Immunology, St. Andrews, Scotland, UK.

Hinds, N., Smith, S.L. (2007). Characterization of constitutive antimicrobial activity associated with leukocyte lysates from the nurse shark, Ginglymostoma cirratum, Poster presented at the Proceedings of the Annual American Society for Immunology, Miami, FL. 